\title{
HYDROLOGY OF AREA 15, EASTERN COAL PROVINCE, KENTUCKY AND TENNESSEE
}

- UPPER CUMBERLAND RIVER

- ROCKCASTLE RIVER

- CLEAR FORK

- POOR FORK

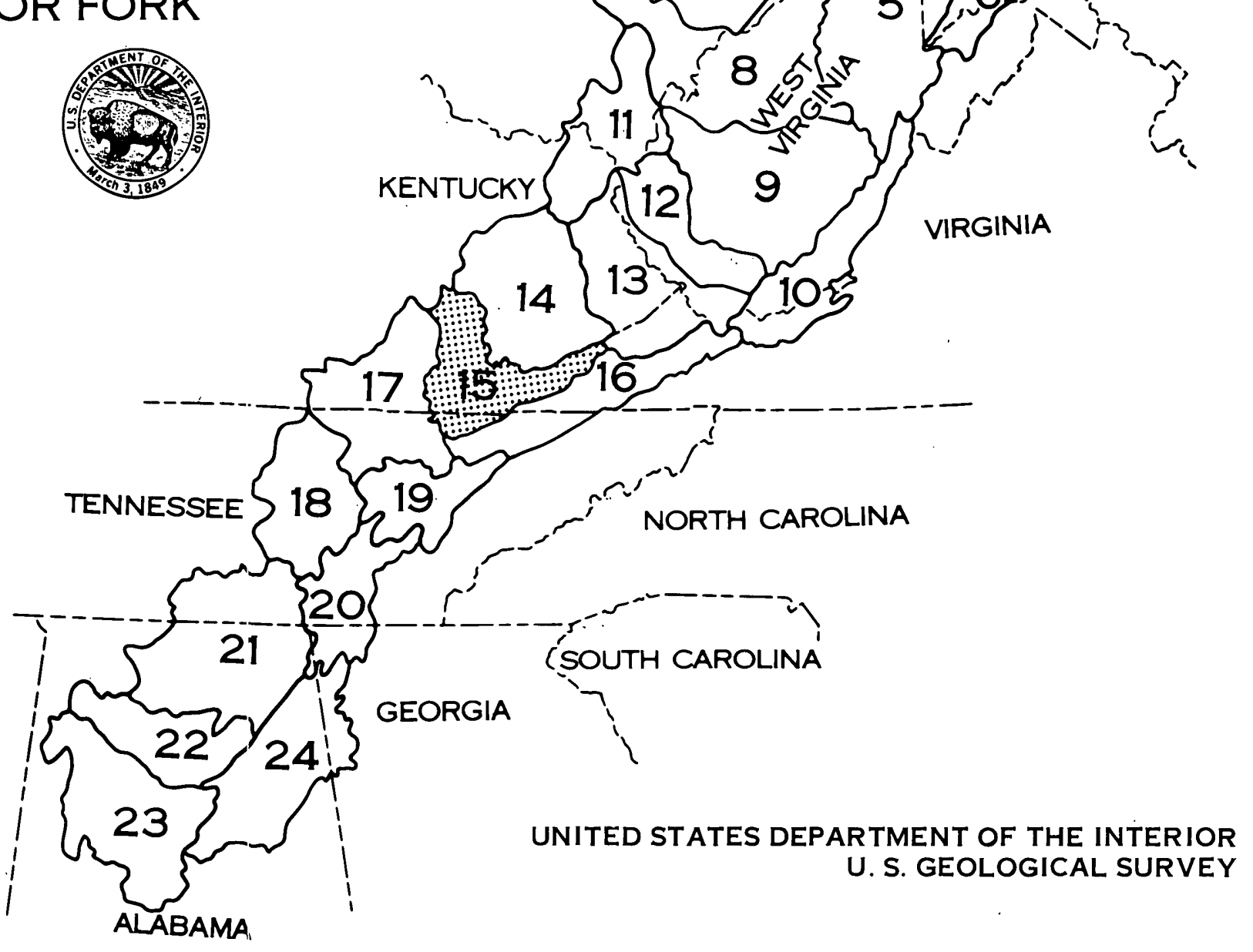

WATER-RESOURCES INVESTIGATIONS OPEN-FILE REPORT 81-809 



\section{HYDROLOGY OF AREA 15, EASTERN COAL PROVINCE, KENTUCKY AND TENNESSEE}

BY

DAVID W. LEIST, FERDINAND QUINONES, DONALD S. MULL, AND MARY YOUNG

U.S. GEOLOGICAL SURVEY

WATER-RESOURCES INVESTIGATIONS

OPEN-FILE REPORT 8.1-809

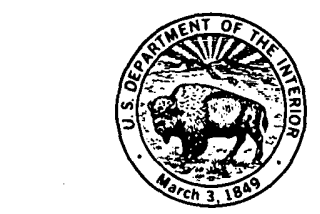

LOUISVILLE, KENTUCKY

JANUARY 1982 
JAMES G. WATT, SËCRETARY

\title{
GEOLOGICAL SURVEY
}

\author{
Dallas L. Peck, Director
}

For additional information write to:

U. S. Geological Survey

Room 572 Federal Building

Louisville, Kentucky 40202 


\section{CONTENTS}

Page

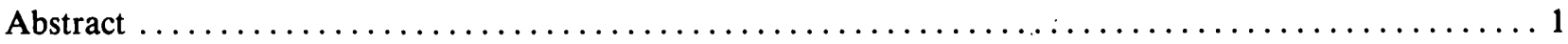

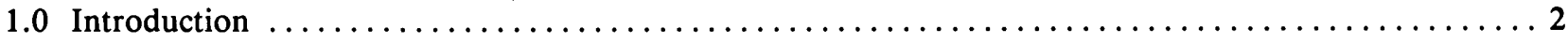

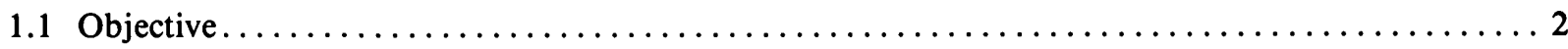

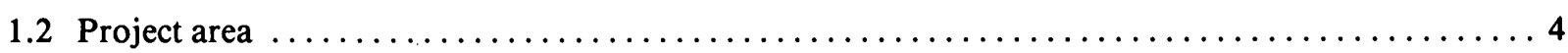

1.3 Hydrologic problems related to surface mining $\ldots \ldots \ldots \ldots \ldots \ldots \ldots \ldots \ldots \ldots \ldots \ldots \ldots \ldots \ldots \ldots \ldots \ldots$

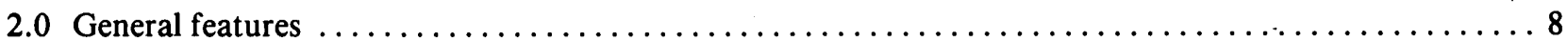

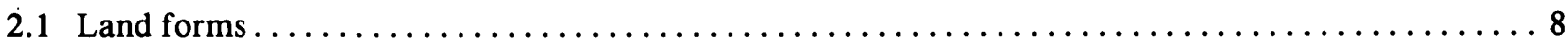

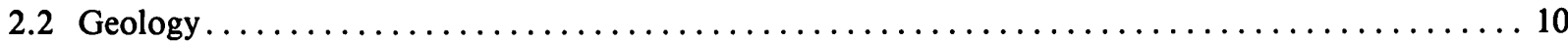

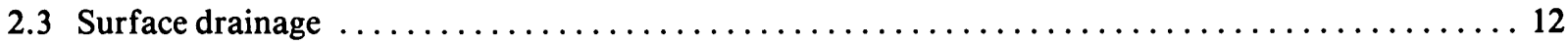

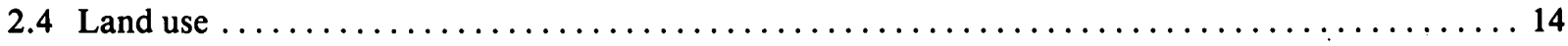

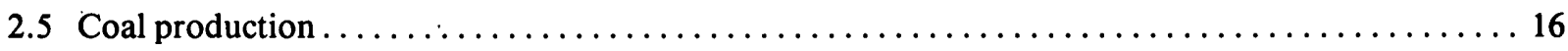

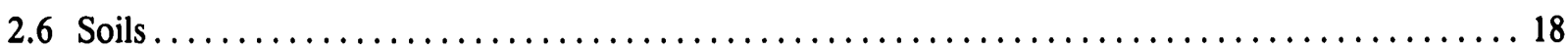

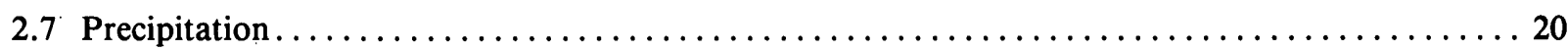

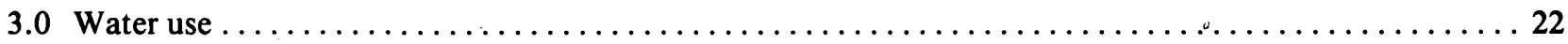

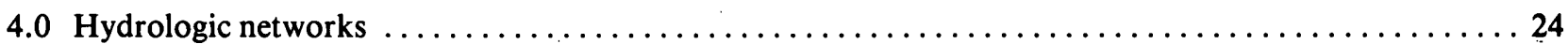

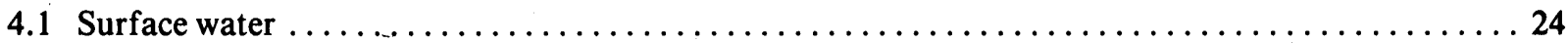

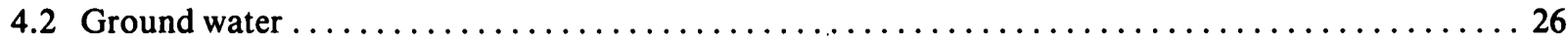

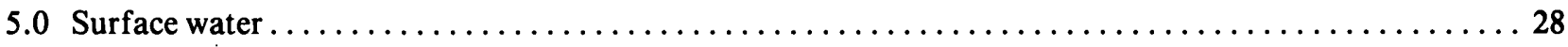

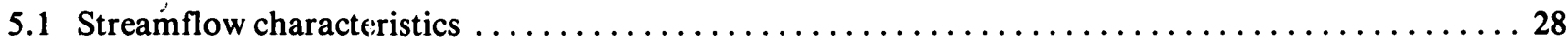

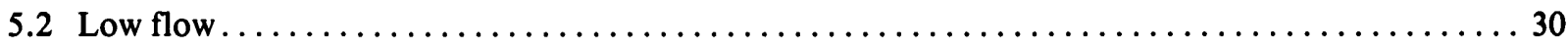

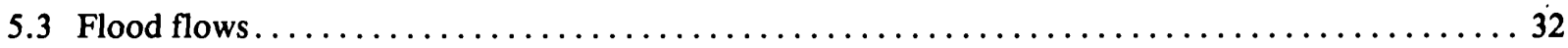

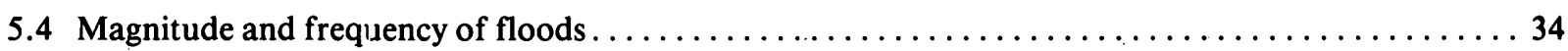

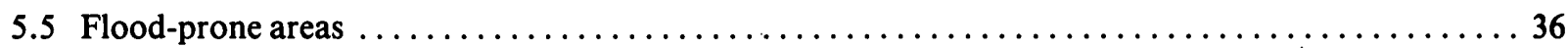

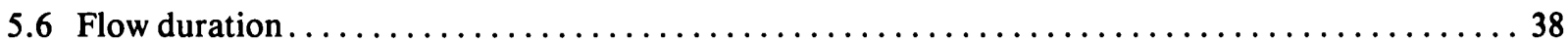

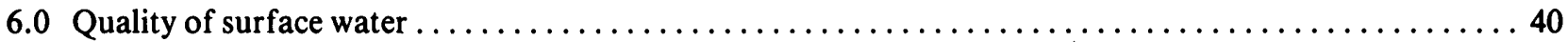

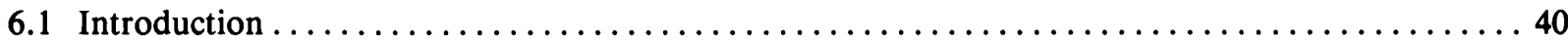

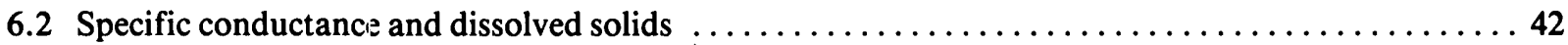

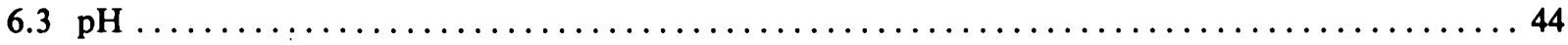

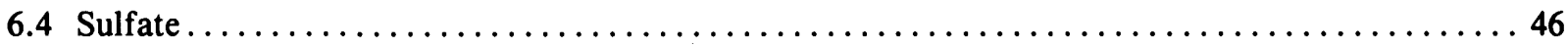

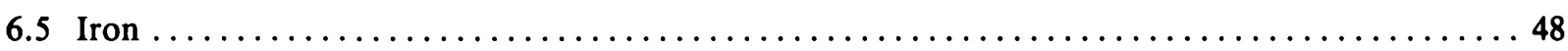




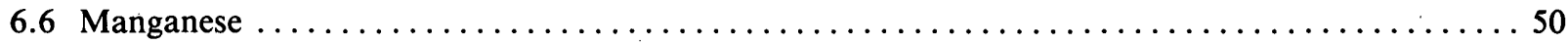

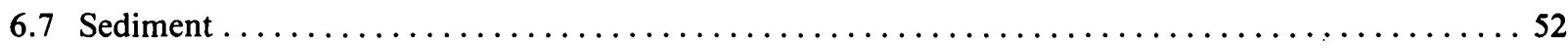

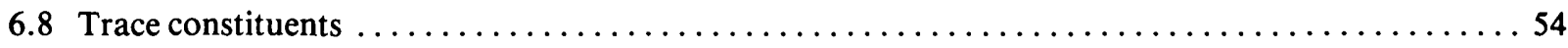

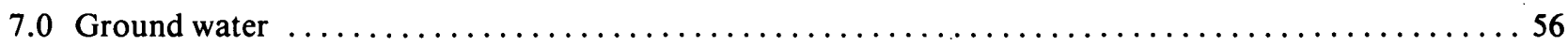

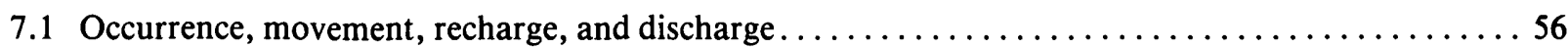

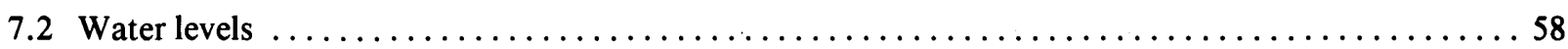

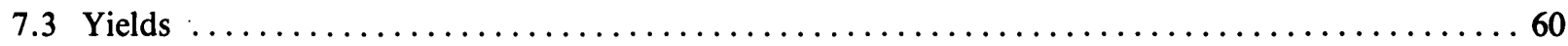

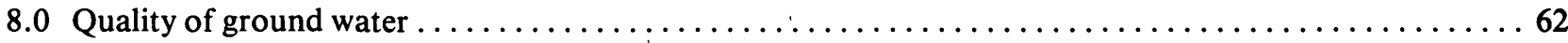

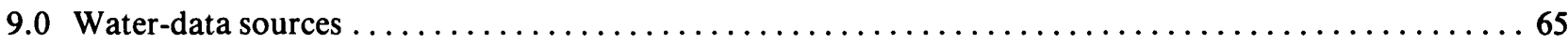

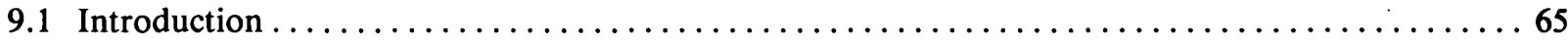

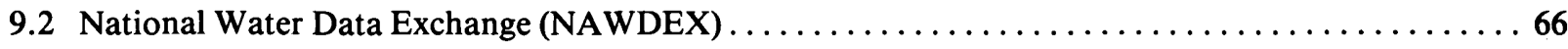

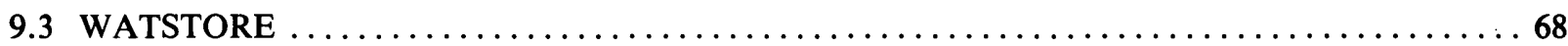

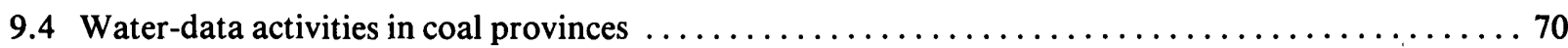

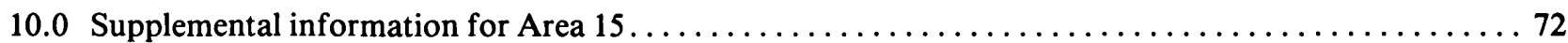

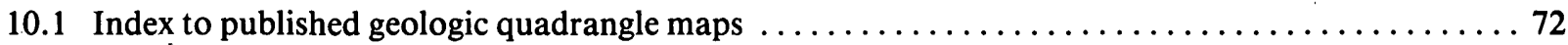

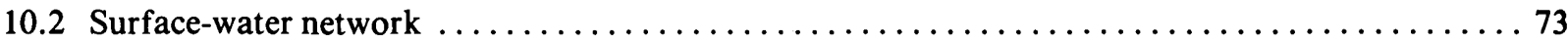

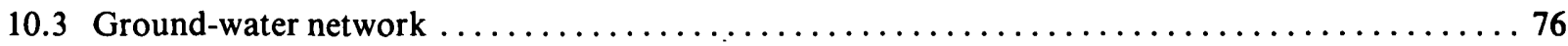

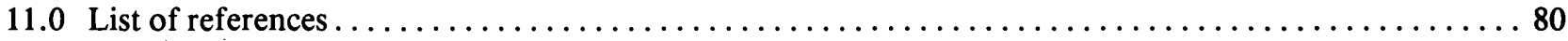




\title{
FACTORS FOR CONVERTING INCH-POUND UNITS TO INTERNATIONAL SYSTEM OF UNITS (SI)
}

For the convenience of readers who may want to use International System of Units (SI), the data may be converted by using the following factors:

\author{
Multiply inch-pound units \\ inches (in) \\ inches per hour (in/h) \\ feet (ft) \\ feet per mile $(\mathrm{ft} / \mathrm{mi})$ \\ miles (mi) \\ square miles $\left(\mathrm{mi}^{2}\right)$ \\ acres \\ acre-feet (acre-ft) \\ gallons per minute (gal/min) \\ million gallons per day $(\mathrm{Mgal} / \mathrm{d})$ \\ cubic feet per second $\left(\mathrm{ft}^{3} / \mathrm{s}\right)$ \\ cubic feet per second \\ per square mile $\left[\left(\mathrm{ft}^{3} / \mathrm{s}\right) / \mathrm{mi}^{2}\right]$ \\ pounds (lb) \\ tons \\ tons per square mile per \\ year $\left[\left(\right.\right.$ tons $\left.\left./ \mathrm{mi}^{2}\right) / \mathrm{yr}\right]$
}

By

To obtain SI units

25.4

millimeters (mm)

25.4

2.54

millimeters per hour $(\mathrm{mm} / \mathrm{h})$

0.3048

0.1894

1.609

2.590

4047.

1233.

0.06309

0.04381

3785 .

0.02832

0.01093

453.6

0.9072

meters (m)

meters per kilometer $(\mathrm{m} / \mathrm{km})$

kilometers $(\mathrm{km})$

square kilometers $\left(\mathrm{km}^{2}\right)$

square meters $\left(\mathrm{m}^{2}\right)$

cubic meters $\left(\mathrm{m}^{3}\right)$

liters per second $(\mathrm{L} / \mathrm{s})$

cubic meters per second $\left(\mathrm{m}^{3} / \mathrm{s}\right)$

cubic meters per day $\left(\mathrm{m}^{3} / \mathrm{d}\right)$

cubic meters per second $\left(\mathrm{m}^{3} / \mathrm{s}\right)$

cubic meters per second per square kilometer $\left[\left(\mathrm{m}^{3} / \mathrm{s}\right) / \mathrm{km}^{2}\right]$

grams (g)

metric tons

metric ton per square kilometer per year $\left[\left(\right.\right.$ metric ton $\left.\left./ \mathrm{km}^{2}\right) / \mathrm{yr}\right]$ 


\section{HYDROLOGY OF AREA 15, \\ EASTERN COAL PROVINCE, KENTUCKY AND TENNESSEE}

BY

AVID W. LEIST, FERDINAND QUINONES, DONALD S. MULL, AND MARY YOUNG

\section{Abstract}

Area 15 is one of 24 hydrologic reporting areas in the Eastern Coal province. This area is in southeastern Kentucky and northeastern Tennessee, within the Appalachian Plateaus province. The Cumberland
and it tributaries, the Laurel and Rockcastle Rivers drain the area of 3,095 square miles.

Rocks of Pennsylvanian and pre-Pennsylvanian age are exposed in Area 15. The Breathitt Formation of the area and contains most of the coal.

Forests cover about 80 percent of Area 15. The errain is steep, with deep valleys and slopes ranging from 20 to 60 percent. The soils are mostly acidic, derived fot 60 save

Coal production is concentrated in Harlan and Bell counties (Ky.), in the Cumberland River basi. Production in 1978 was about 22 million tons, with surface mines accounting for about $\overline{52}$ percent of the

Annual average precipitation ranges from 46 to 55 inches. The 10-year 24-hour rainfall frequency storm averages about 4.5 inches.

Water use in 1975 averaged about 12.9 million gallons per day. Surface water supplied about 80 important water uses in the area?

Hydrologic data are available for 59 active and 27 inactive surface-water sites. Streamflow varies seasonally and geographically. Average annual runnoff at sites in the Cumberland River basin (mined) is about 25.6 inches per square mile, whereas average annual runoff is about 19.9 inches per square mile. Low flows in the area are poorly sustained, with a 7-day 10-year minimum flow of zero at many streams draining less than 100 square miles.
Floods are frequent and severe in the area. They gy. Flood frequencies and magnitudes can be estimated from regression equations. Twenty-two maps delineating the limits of the 100-year and the

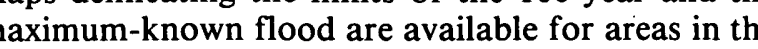
basins of the Cumberland and Laurel Rivers.

Water-quality data are available from 38 active varies from near-natural conditions of less than 100 milligrams per liter of dissolved solids at sites in the largely unmined Rockcastle River basin, to as much as 1,040 milligrams per liter of dissolved solids at sites in the mined Cumberland River basin.

Acid-mine drainage generally is naturally neutralized near its source. Most of the water in streams
in the area has near-neutral pH values in the 7 to 8 units range.

Dissoived sulfate is a significant water-quality parameter that can be related to mining activities in Area 15. In basins where mine-drainage is not sig4.5 to 74 milligrams per liter. In basins where surface coal-mining activities are significant, dissolved sulfate concentrations are as high as 998 milligrams per liter with median concentrations exceeding 50 milligrams per liter. Sulfate concentrations correlate well sites.

Most of the iron in streamflow is in suspension The amount of iron in solution is relatively minor. Dissolved manganese constitutes more than half of the total recoverable manganese. Its concentration does not increase or decrease significantly with are higher in waters of mined basins than in unmined basins.
Suspended-sediment data are inadequate to calculate sediment yields in most basins. Suspendedsediment yields are highest in basins affected by surface mining but vary seasonally. Most of the curly

In general, trace constituents do not occur in bottom sediments of streams. However, dissolved mercury concentrations at some sites exced max$\mathrm{m}$ recommended limits for aquatic life.

Ground water in Area 15 occurs in multiple Lee Formations. Precipitation provides most of the recharge to the area aquifers. Ground-water levels huctuate seasonally and water levels range from Yieve land surface to 300 feet below land surface. Yields to wells range from about 1 to 250 gallons per 50 gallons per minute from pre-Pennsylvanian formations.
Ground-water quality is highly variable but is enerally suitable for most purposes. Waters range from soft to very hard and contain iron concentraWhster with ere than 1,00025 milligrams per liter. War with fissot bed solids coms in 1,000 milligrams at pepths of 300 tions. 


\subsection{INTRODUCTION \\ 1.1 Objective}

\section{Area 15 Report to Aid in Preparing and Appraising Mine Permit Applications}

\section{Existing hydrologic conditions are described and identification of sources of hydrologic information are presented.}

\begin{abstract}
A need for hydrologic information and analysis on a scale never before required nationally was initiated when the "Surface Mining Control and Reclamation Act of 1977" was signed into law as Public Law 95-87, August 3, 1977. This need is partially met by this report which broadly characterizes the hydrology of a large sub-basin in the eastern coal area of Kentucky and Tennessee(fig. 1.1-1). This report, which is for Area 15, is one of a series that covers the coal provinces nationwide. The report contains a brief text with an accompanying map, graph, or other illustration for each of a number of water-resources related topics. The summation of the topical discussions provides a description of the hydrology of the area.
\end{abstract}

The hydrologic information presented or availa- ble through sources identified in this report, may be used in describing the hydrology of the general area of any proposed mine. Furthermore, it is expected that this hydrologic information will be supplemented by the lease applicant's specific site data as well as data from other sources to provide a more detailed picture of the hydrology of the area in the vicinity of the mine and the anticipated hydrologic consequences of the mining operation.

The information contained herein should be useful to surface mine owners, operators, and consulting engineers in the preparation of permits, and to regulatory authorities in appraising the adequacy of permit applications. 


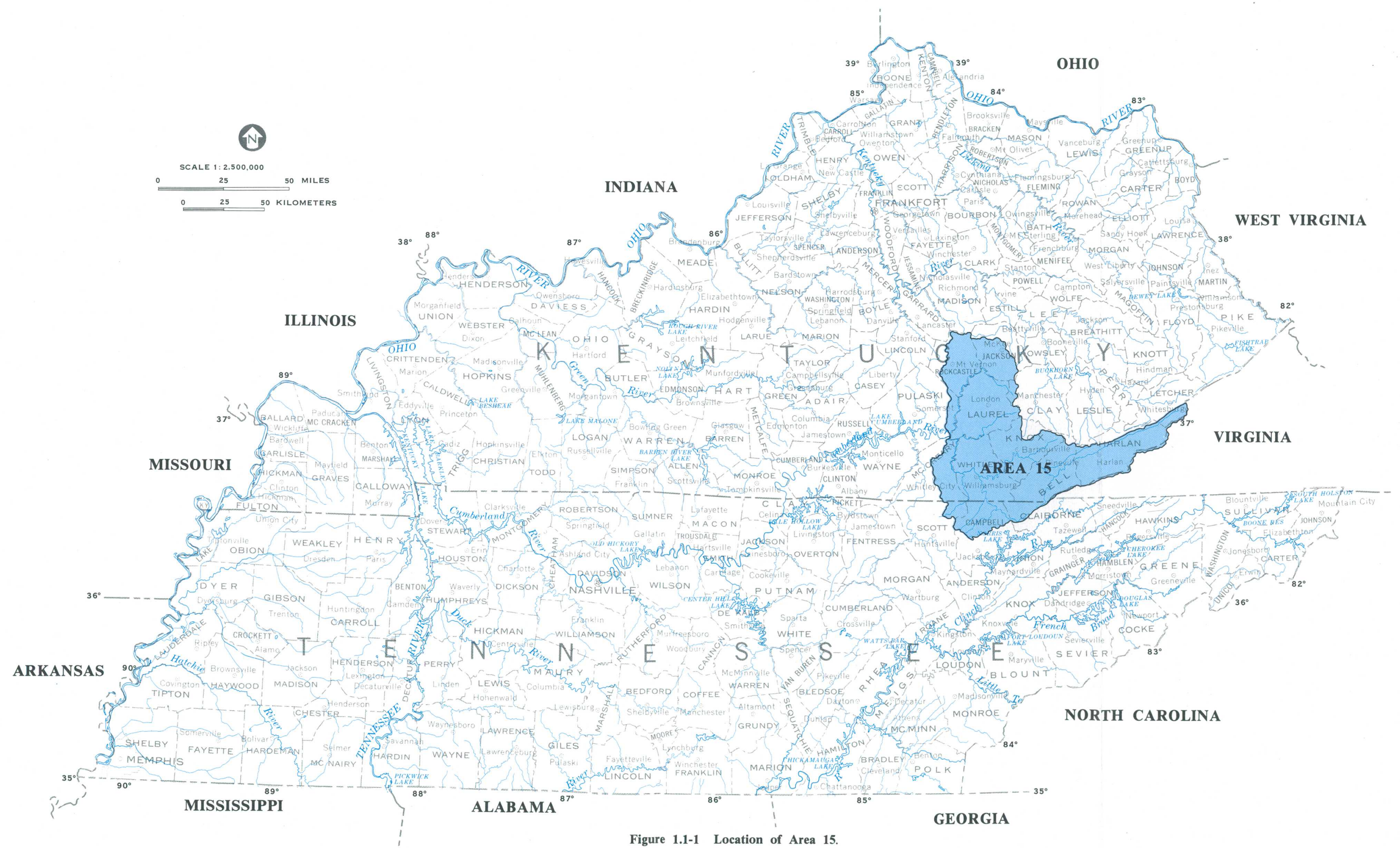




\title{
1.0 INTRODUCTION--Continued \\ 1.2 Project Area
}

\section{Area is in Central Part of Eastern Coal Province}

\author{
Area 15 comprises 3,095 square miles of the Cumberland, Rockcastle, and \\ Laurel River basins in southeastern Kentucky and northcentral Tennessee.
}

The Eastern Coal province has been divided into 24 hydrologic reporting areas (see cover). The divisions are based on drainage boundaries, location of basins, size, hydrology, and mining activities. Several drainage basins or parts of basins are combined to form one reporting area (fig.1.2-1). Area 15 is in the central part of the province.

The area is in southeastern Kentucky and northcentral Tennessee. It includes $3,095 \mathrm{mi}^{2}$ of the Cumberland, Rockcastle, and Laurel River basins. About 90 percent of the project area is in Kentucky and about 10 percent is in Tennessee. The area is within the Eastern Coal province and is part of Fenneman's
(1938) Appalachian Plateaus physiographic province (fig. 1.2-2). It includes all or parts of Harlan, Bell, Knox, Whitley, McCreary, Laurel, Letcher, Rockcastle, and Jackson counties in Kentucky, and Clairborne, Campbell, and Scott counties in Tennessee.

The population of Area 15 is about 200,000 people. It is mostly rural, with about 30 percent of the total residing in Harlan and Bell counties where coal mining is the principal industry. The area's principal cities -- Middlesboro, Harlan, Cumberland, Barbourville, London, Corbin, and Williamsburg -are in Kentucky. 


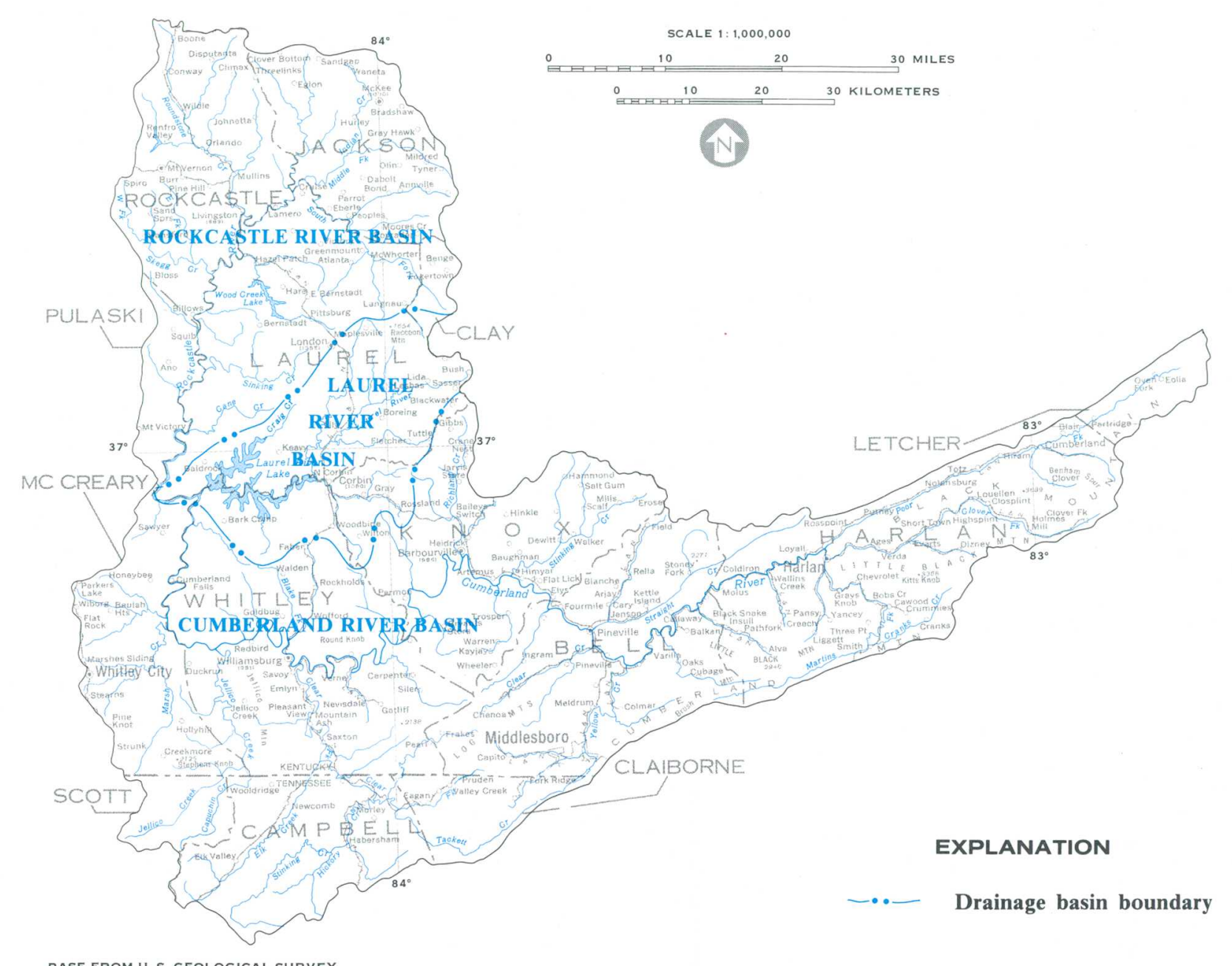

BAEE FROMU. S. SEEOLOGICAL SURVEY
STATE BASE MAP, 1973

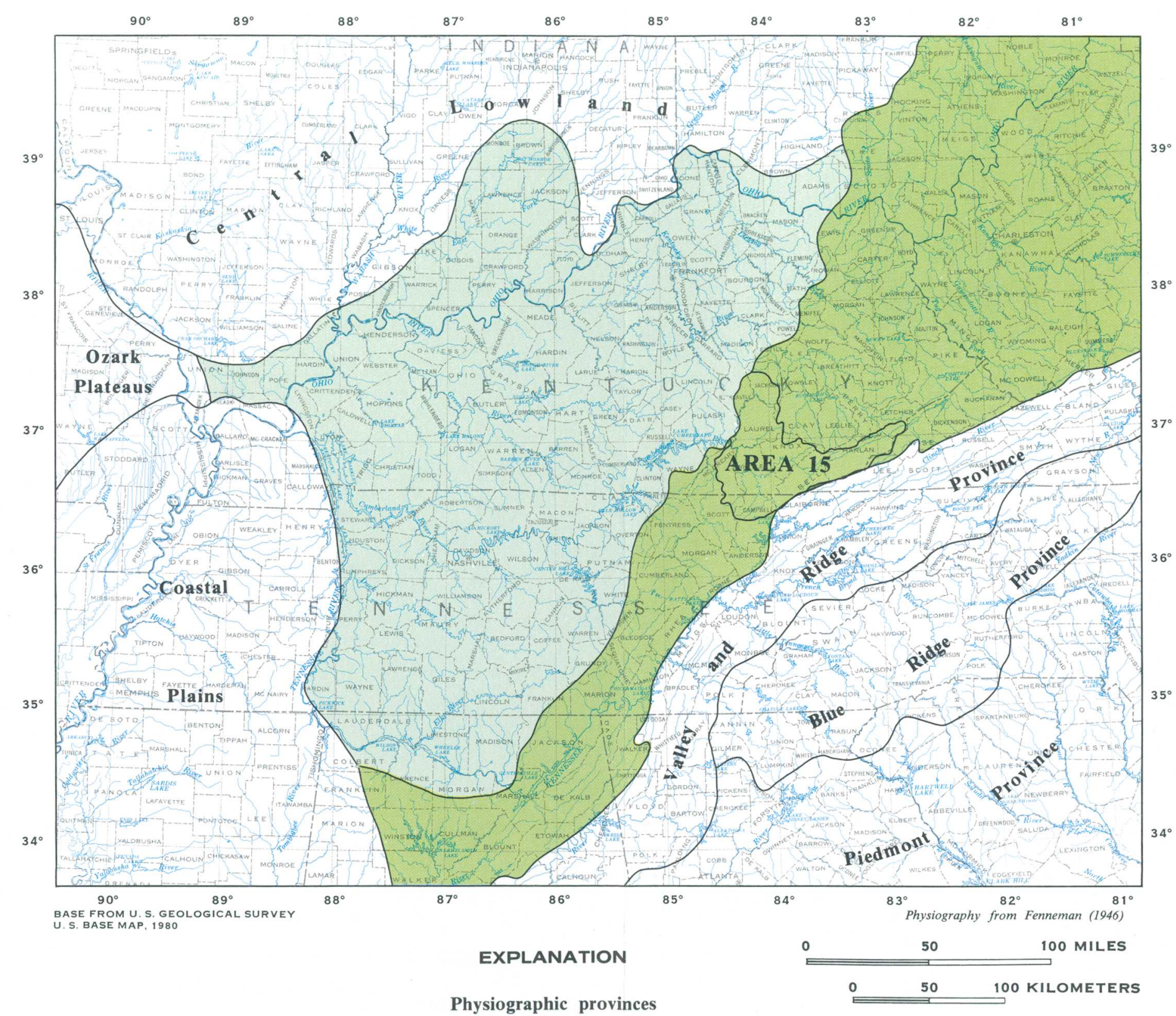

Physiographic provinces

Interior Low Plateaus

Appalachian Plateaus

Figure 1.2-2 Physiographic provinces. 


\title{
Hydrologic Environment Can be Adversely Altered by Surface Coal Mining
}

\author{
Erosion, sedimentation, decline in water levels, and degradation of water \\ quality are typical problems associated with surface coal mining.
}

Surface mining drastically alters the environment of undisturbed areas and may cause detrimental changes to the environment. Mining activities such as the removal of vegetation, excavation, and dumping of large volumes of unconsolidated spoil materials may create unstable areas of loose earth and rock. These generally erode easily and may contribute, if not controlled, additional sediment to surface streams, channels, and flood plains. If the mined area is reclaimed shortly after mining is completed, some of the detrimental environmental effects can be decreased or prevented.

Adverse effects associated with erosion and increased sedimentation include excessive sediment deposition in streams and reservoirs which in turn increases the cost of maintaining navigation channels and treating water for industrial and domestic uses. Other adverse effects include destruction of wild-life habitat, increased flooding due to filling of the stream channels and flood plains by sediment, and reduction of aesthetic value and recreation use.

Along with increased sedimentation, another common and troublesome water-quality problem is acid-mine drainage. After mining, accelerated weathering of iron-bearing minerals (pyrite and marcasite, for example) in spoil materials and coal beds produces sulfuric acid and accelerates the dissolution of minerals (fig. 1.3-1). Water draining such a mined area generally has low pH values (2.5-5.0 units), and increased sulfate and dissolved-solids concentrations. The acidic water reacts with other minerals, increasing concentrations of metals such as copper, lead, iron, manganese, and zinc. Adverse effects associated with acidic and highly mineralized mine drainage may include reduction of aquatic life, increased corrosiveness of water, limitations on the use of water for domestic and industrial purposes, and reduction of aesthetic value and recreational use.

The adverse effects are most apparent on and near the mine site. The receiving stream for surface and seepage drainage at the mine site usually is most affected. Problems caused by suspended sediment, increased metals content, and low $\mathrm{pH}$ values will usually diminish in severity downstream from the mine. This is due to settling out of the sediment, and the increased buffering and dilution capacity of the stream.

Decline of ground-water levels can occur in and near surface-mining areas when excavation extends below the water table causing some wells and springs to go dry (fig. 1.3-2). The quality of ground water can also be affected even though the effect may take much longer to detect at points remote from mining activities.

The magnitude of the effect of surface mining on the surrounding hydrologic environment depends on several physical and chemical factors. The more influential factors include mining and reclamation methods, topography, geology, climate, rate of water movement and volumes, the distance to the mine site, and the time elapsed since mining began.

Some generalized chemical and physical relations and trends that can result from surface coal mining are shown in figure 1.3-3. 


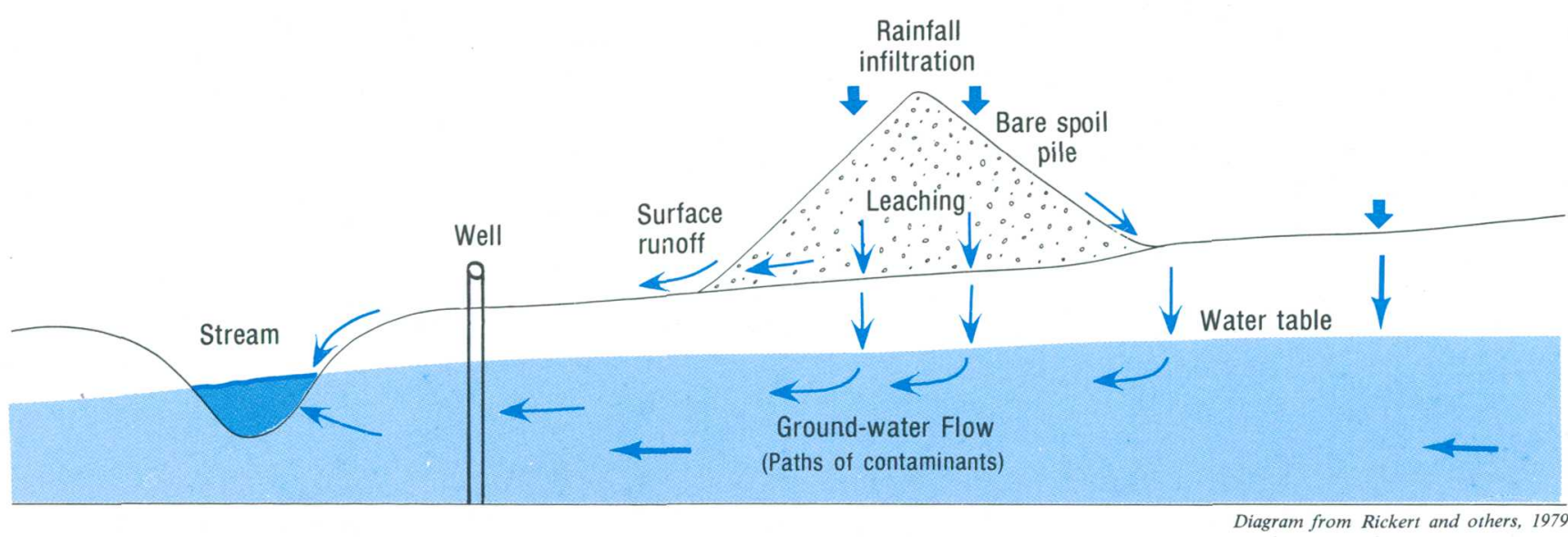

Figure 1.3-1 Leaching spoil material

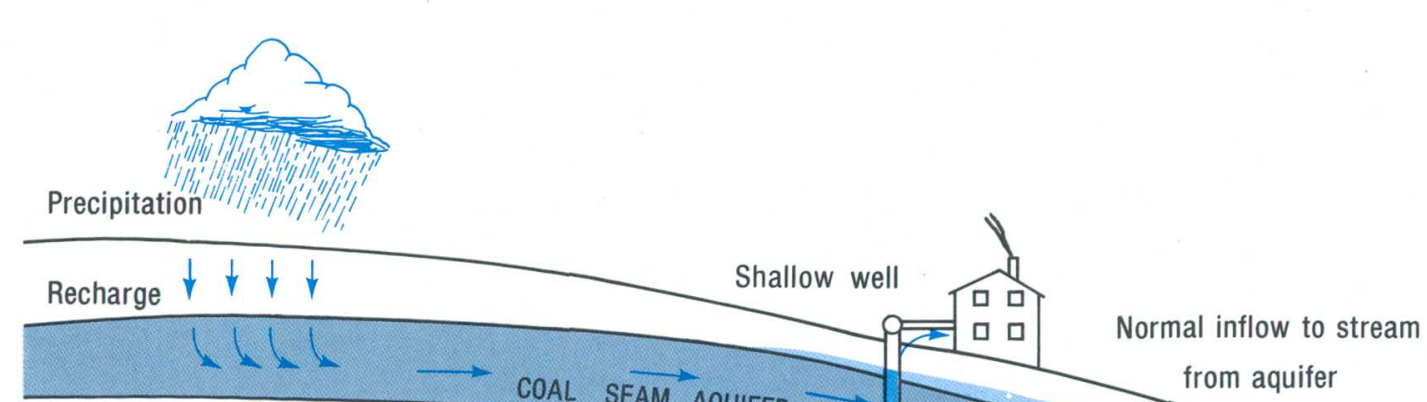

A. PREMINING CONDITION

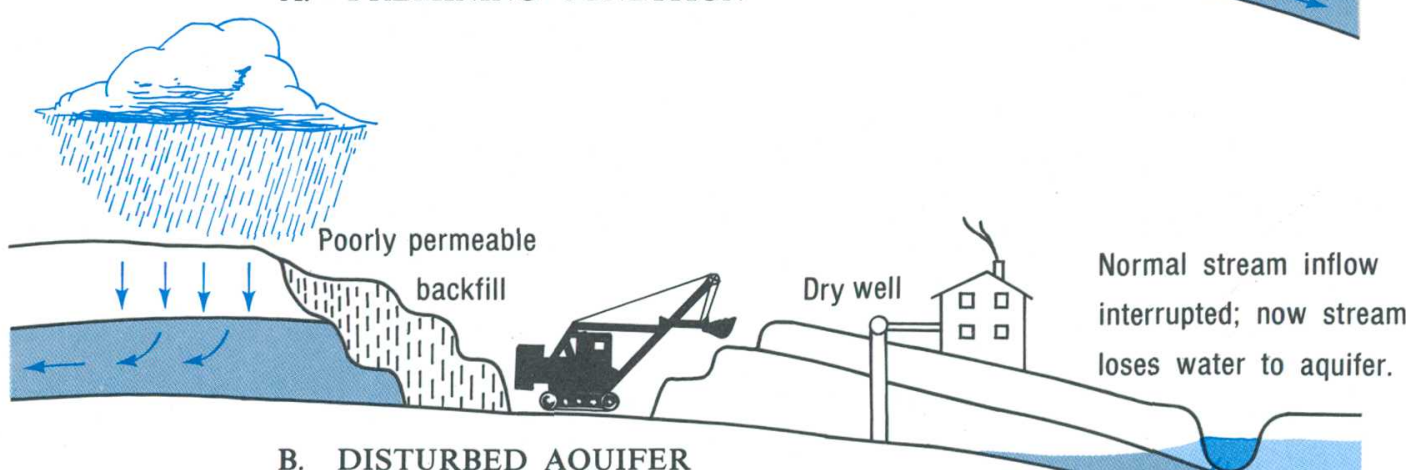

B. DISTURBED AQUIFER

(Reclaimed overburden is poorly permeable impeding ground water movement)

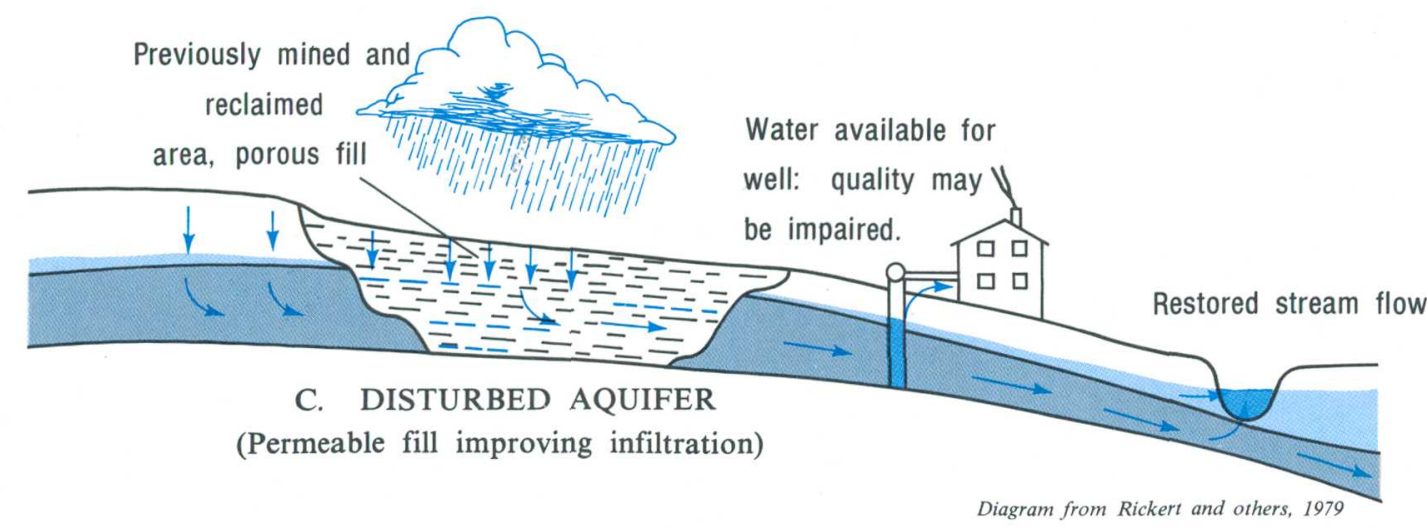

Figure 1.3-2 Possible impacts of mining aquifers
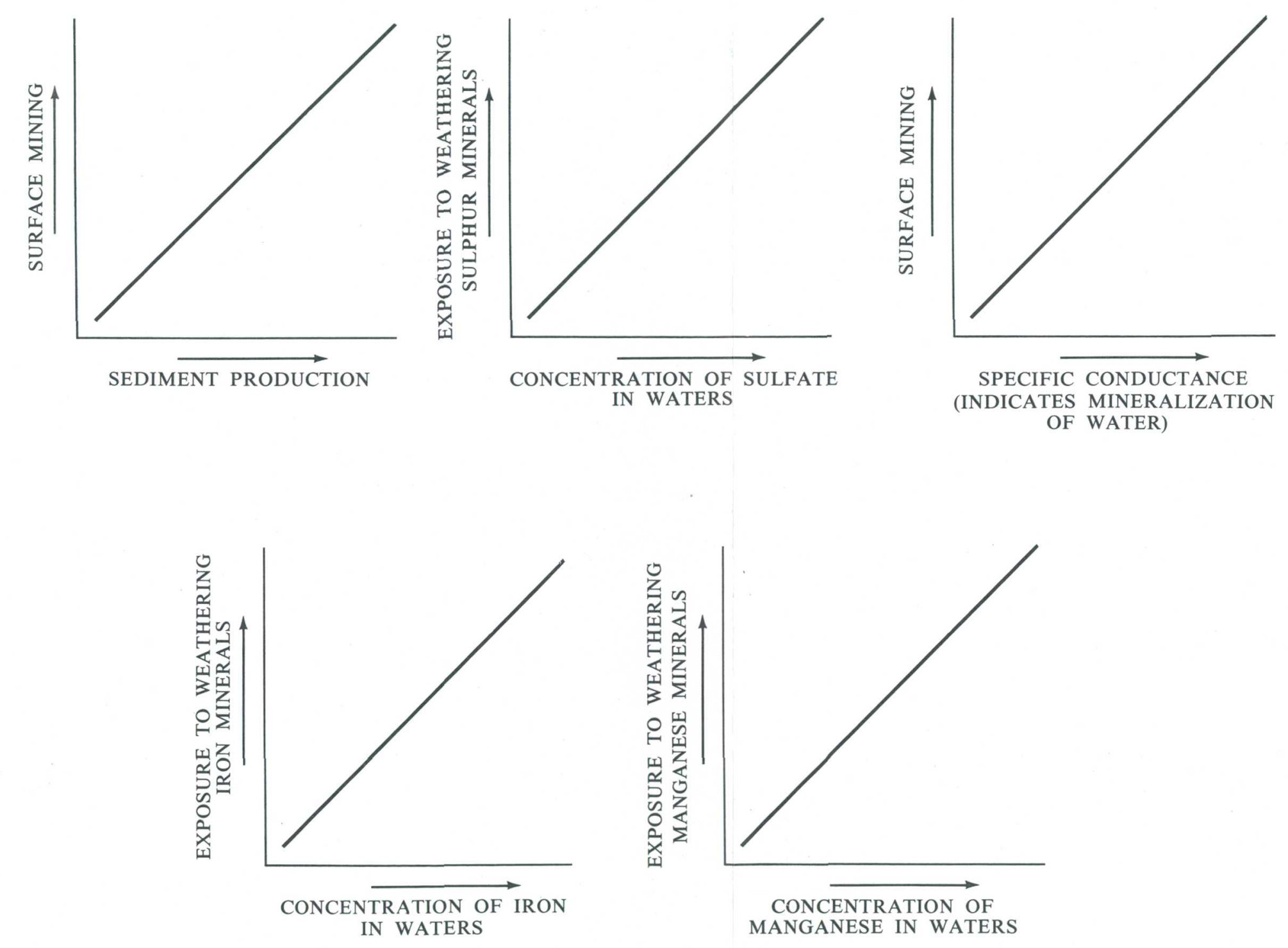

Relations and trends from Mav and others, 198

Figure 1.3-3 Generalized relations and trends that can result from surface coal mining. 


\subsection{GENERAL FEATURES}

2.1 Land Forms

\section{Area Within Three Physiographic Sections}

\section{The area is in the Cumberland Mountain, Cumberland Plateau, and Kanawha sections of the Appalachian Plateaus province.}

\begin{abstract}
Area 15 lies within the Appalachian Plateaus physiographic province (fig. 2.1-1; Fenneman 1938, 1946) which is subdivided into the Cumberland Mountain, Kanawha, and Cumberland Plateau sections (fig. 2.1-2). The Cumberland Mountain section consists of two parallel ridges; Pine Mountain and Cumberland Mountain, ranging from about 2,000 to 3,000 feet in altitude. Rugged hills lie between Pine and Cumberland mountains. The Kanawha section is a dissected plateau characterized by narrow, crooked valleys, and narrow, irregular steep-sided
\end{abstract}

ridges. This section is underlain by sandstone, siltstone, and shale of Pennsylvanian age. The Cumberland Plateau section is a broad plateau of moderate relief. Along its western margin it is intricately dissected into very narrow ridges which are bordered by deep valleys having steep walls. The surface of the upland is shale and sandstone of Pennsylvanian age. In the northwest part of the area, the valleys and part of the ridges are shale and limestone of Mississippian age. 

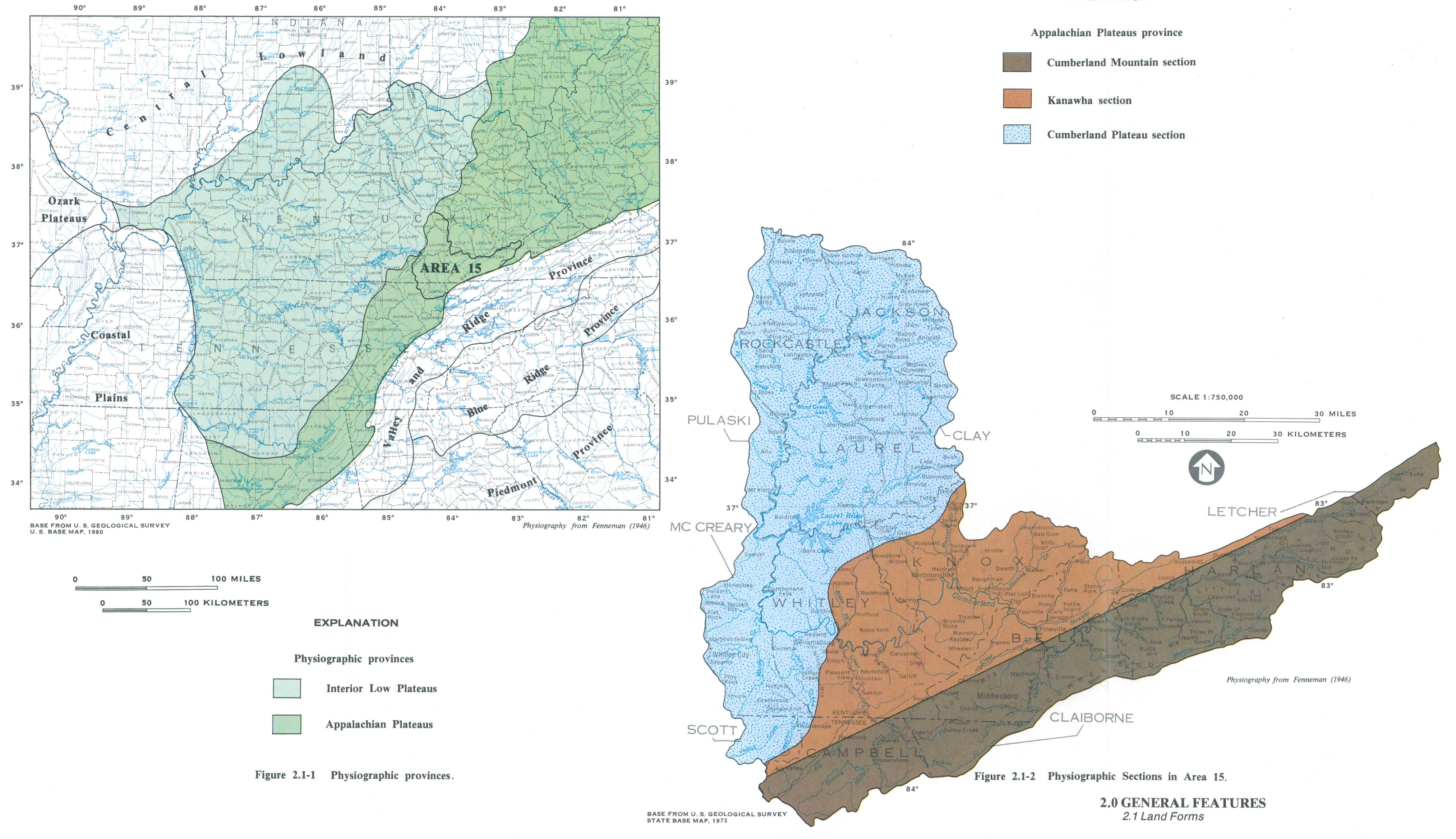

Physiographic provinces

$\square \quad$ Interior Low Plateaus

Appalachian Plateaus

Figure 2.1-1 Physiographic provinces

.0 GENERAL FEATURES 


\title{
2.0 GENERAL FEATURES--Continued \\ 2.2 Geology
}

\section{Three Major Rock Types Underlie Area}

\author{
Shale and sandstone of the Breathitt and Lee Formations of Pennsylvanian age \\ and shale and limestone of Mississippian and Devonian age underlie the area. \\ Coal occurs in the rocks of Pennsylvanian age.
}

Pennsylvanian age rocks in Area 15 are subdivided into the Breathitt and Lee Formations. Differences in geologic names east and west of Pine Mountain in Kentucky and usage of different names in Tennessee complicate the correlation of strata in the area. Therefore, for convenience in this report, all strata younger than the Lee Formation, as recognized in Kentucky, are grouped together into the Breathitt Formation.

The Breathitt Formation, which crops out in about 75 percent of Area 15, contains most of the minable coal (fig. 2.2-1). It has a maximum thickness of about 2,500 feet and consists of sandstone, siltstone, shale, underclay, coal, ironstone, and very little limestone. Sandstone units (30 to 120 feet thick) commonly show frequent lateral lithologic changes and rarely form area-wide mappable units. Siltstone and shale intergrade, are commonly carbonaceous, and contain plant fragments. Ironstone occurs principally as siderite concretions in thin lenses or nodules in shale or siltstone (Rice and others, 1979). As many as 25 coal beds are present in the formation (fig. 2.2-2) and individual beds are as much as 64 inches thick. Intervals between the principal coal beds range from a few feet to nearly 400 feet (Huddle and others, 1963). Individual coal beds usually have a wide lateral extent, but may vary considerably in thickness within a given area or may be cut out by channel-fill sandstone. These characteristics, in combination with the many different names given to coal beds, make area-wide correlation of individual coal beds difficult.

Rocks of the Lee Formation are exposed in the western part of the area and near the crest of Pine and Cumberland Mountains. They underlie the Breathitt Formation throughout Area 15. In the central part of the area the Lee Formation is exposed only in the larger and more deeply eroded valleys and in some of the areas of structural highs. The formation consists of conglomerate, sandstone, siltstone, calcareous shale, underclay, and coal and is characterized by massive beds of orthoquartzite that locally contain conglomerate lenses. Sandstone makes up more than 80 percent of the formation which has in places been divided into six mappable members, the lower members in places intertongue with the underlying Mississippian rocks. Shale, siltstone, and coal are frequently interbedded and are more common in the upper part of the formation. As many as 15 coal beds are in the Lee Formation, but only three have been mined extensively. The coal beds are usually thin and markedly lenticular. The Lee Formation ranges in thickness from 350 feet in the north to 1,500 feet or more in the southeastern part of the area.

Pre-Pennsylvanian rocks of Mississippian and Devonian age are undifferentiated in this report. Mississippian age rocks are exposed in the deep valleys in the northern part of the area and Mississippian and Devonian rocks are exposed along the northern slope of Pine Mountain. The pre-Pennsylvanian age rocks consist of limestone, shale, siltstone, and sandstone and range in thickness from $\mathbf{4 0 0}$ to about 700 feet.

The strata in Area 15 have a regional dip of about 20 feet per mile to the southeast. Superimposed on this gentle regional dip are synclines, anticlines, and basins. The major structural features are the Pine Mountain fault (which is the northwest border of the Cumberland overthrust block), the Rocky Face fault, and the Middlesboro syncline. The Middlesboro syncline is bounded by Pine Mountain on the northwest and Cumberland Mountain on the southeast. Strata near the center of the syncline are relatively flat lying but the dips of strata on Pine and Cumberland Mountains range from 10 to 65 degrees. The strata dip into the basin and form a broad trough that trends from the southwest to the northeast along the southeastern border of the area. The Middlesboro syncline is broken by the Rocky Face fault, a transverse fault zone, which extends between Cumberland Gap and Pineville Gap. Geologic structure has little effect on mining except 


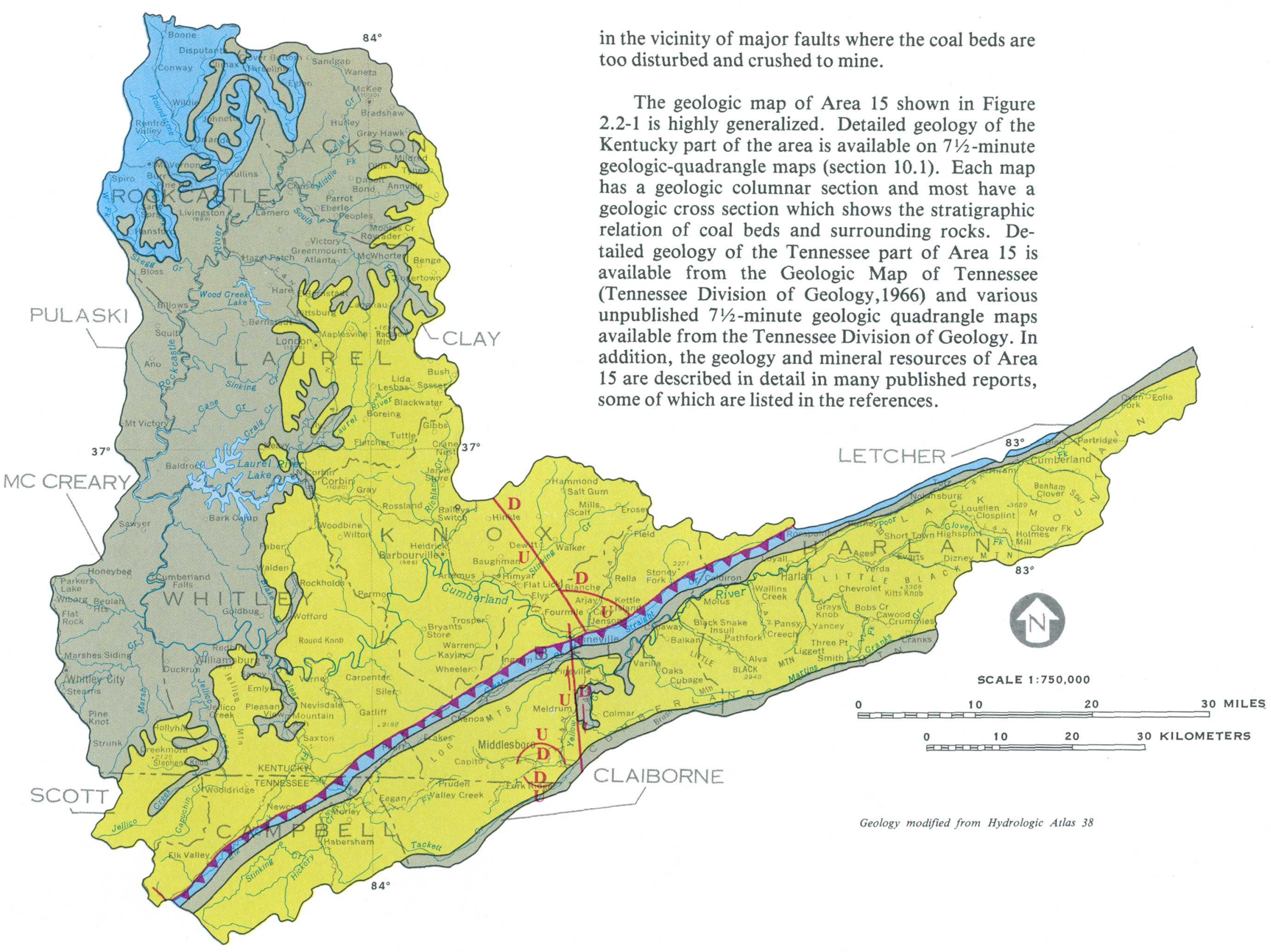

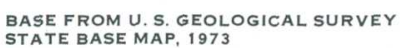

EXPLANATION

\section{Breathitt Formation}

Pennsylvanian

Siltstone, sandstone, clay shale, coal underclay and some limestone

Lee Formation

Sandstone, conglomerate, shale, coal and underclay

\section{SOUTH}

\section{iddlesboro syncline}

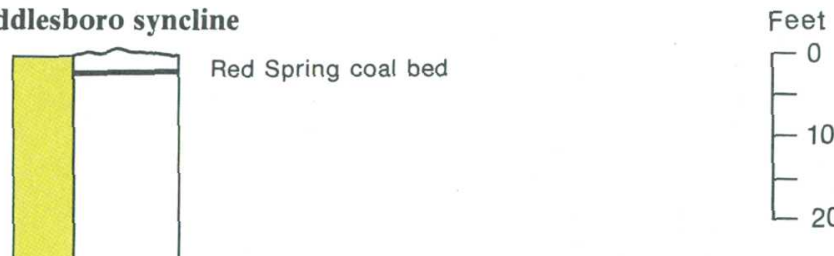

NORTH AND EAST

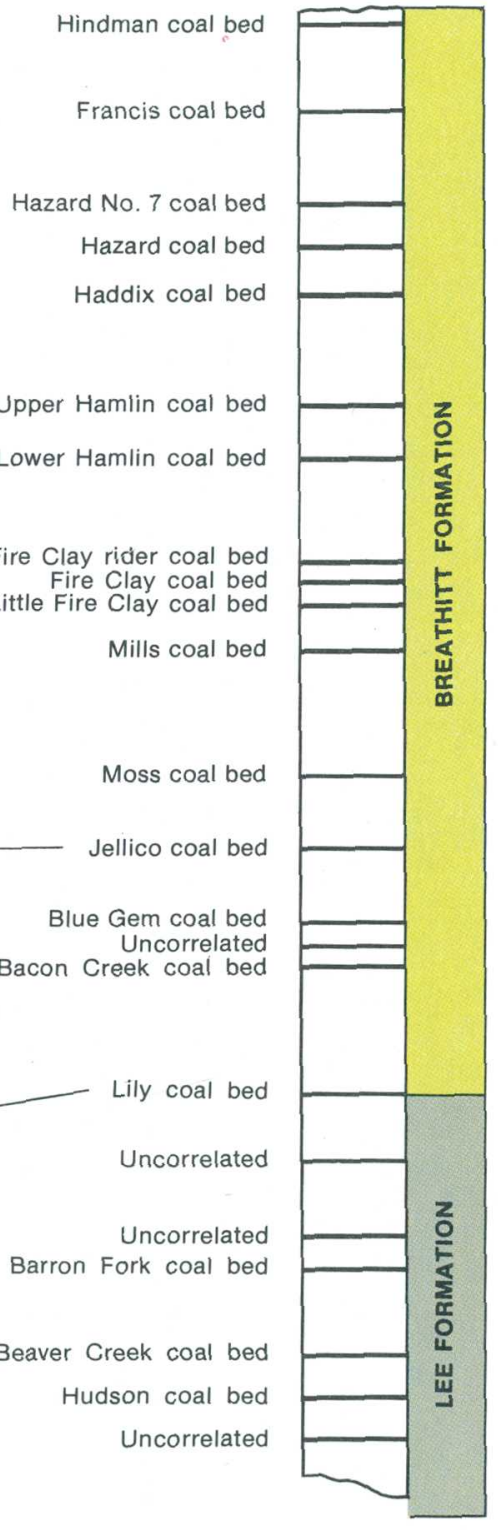

Figure 2.2-2 Generalized geologic columns in the Eastern Coal Field region

Pre-Pennsylvanian $\square$ Shale, limestone, sandstone, and siltstone

Thrust Fault

wteeth on upper plate

D Faults

indicate relative movement: $\mathrm{U}$ upthrown side; $\mathrm{D}$ downthown

Figure 2.2-1 Generalized geolog 


\subsection{GENERAL FEATURES--Continued 2.3 Surface Drainage}

\section{Cumberland River Drains Area}

\section{The Rockcastle and Laurel Rivers are major tributaries to the Cumberland River within the area.}

The Cumberland River is the principal stream in Area 15. It flows from the confluence of Poor and Clover Forks in Harlan County, along the edge of Cumberland Mountain, and drains heavily-mined and high-relief areas before flowing through the Daniel Boone National Forest (fig. 2.3-1). It enters Cumberland Lake, flows through a series of reservoirs in northern Tennesse, ending with Lake Barkley, and empties into the Ohio River at Smithland in western Kentucky. The confluence of the Cumberland River with the Laurel River and the Rockcastle River is in Area 15, near the western boundary, within the Daniel Boone National Forest. Other principal tributaries of the Cumberland River are Poor Fork, Clover Fork, Martins Fork, Clear Fork, and Jellico Creek.

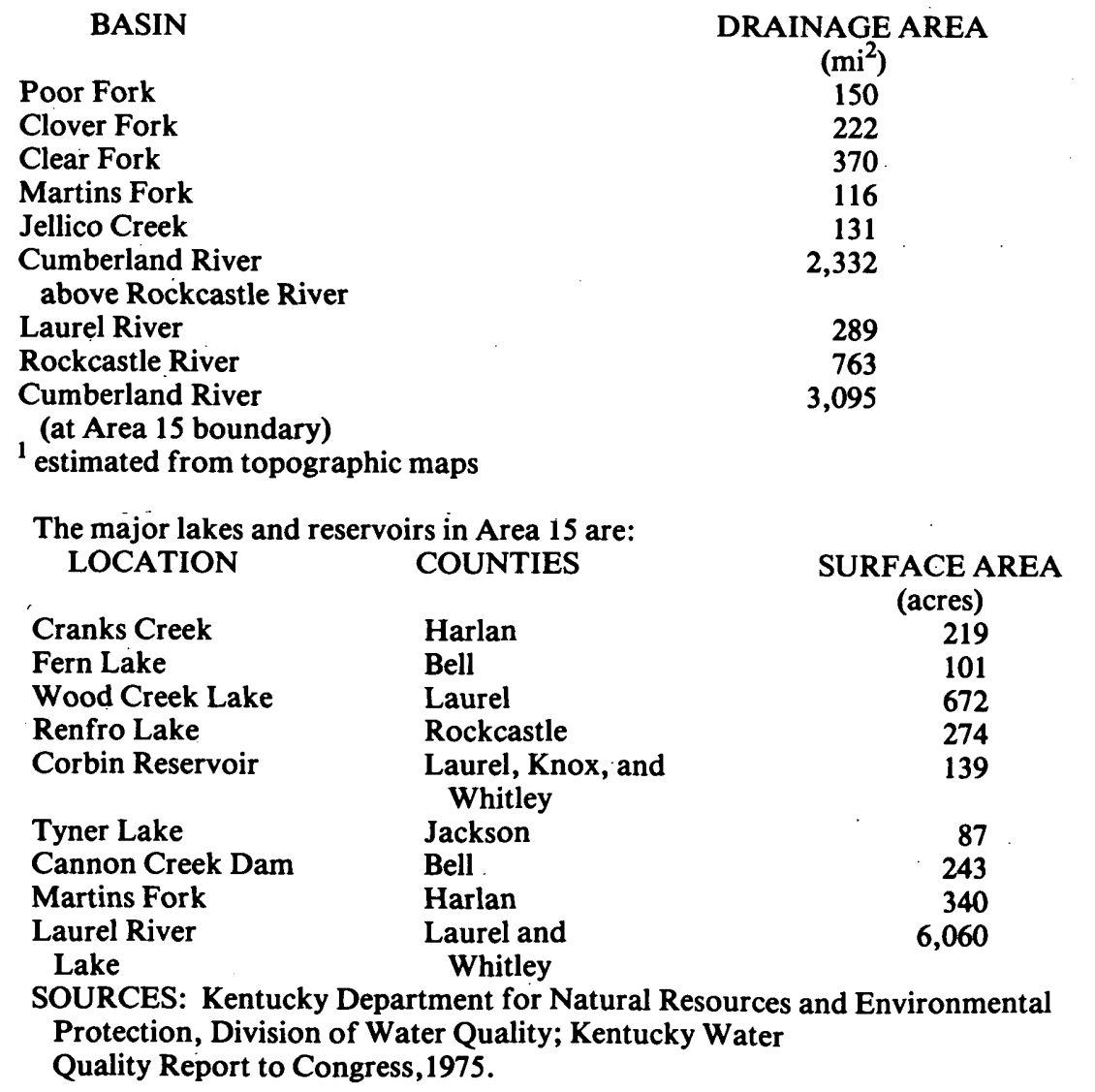

Laurel River drains most of Laurel County before flowing into Laurel River Lake, which is also within the National Forest. From this lake, the Laurel River flows into the Cumberland River.

Rockcastle River drainage is primarily within the National Forest, in Rockcastle, Jackson, and Laurel counties. Its main tributaries are the South and Middle Forks, and Roundstone Creek. It flows into the Cumberland River downstream from Laurel River.

Drainage areas and average slopes of the major rivers and tributaries in Area 15 are:

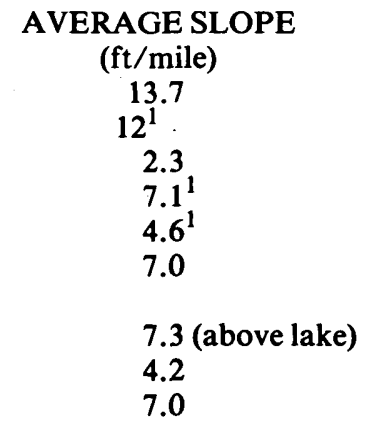

$$
\begin{array}{r}
\text { CAPACITY } \\
\text { (acre-ft) } \\
6,400 \\
902 \\
23,270 \\
4,404 \\
2,500 \\
\\
2,364 \\
11,300 \\
21,120 \\
435,600
\end{array}
$$




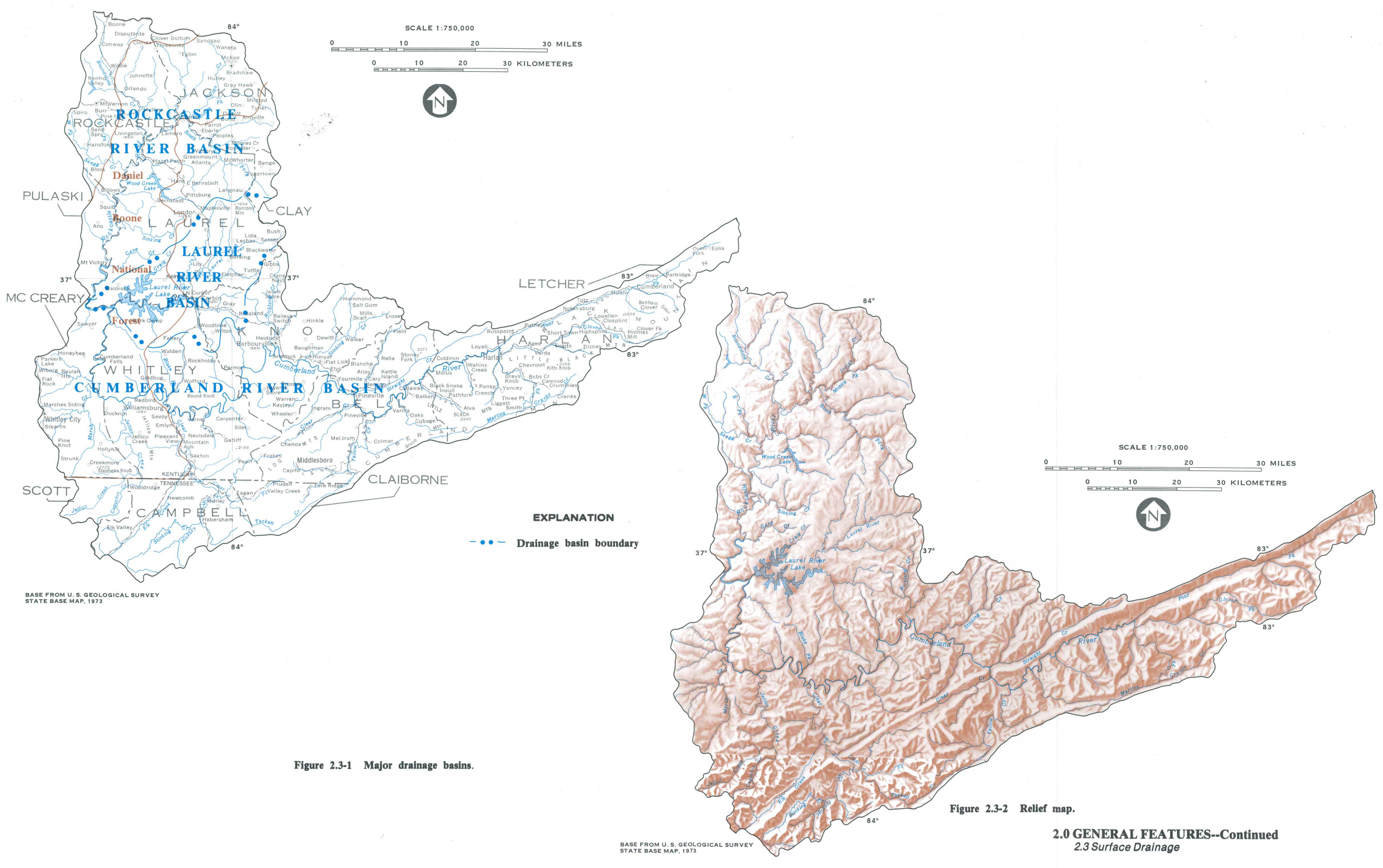




\subsection{GENERAL FEATURES--Continued \\ 2.4 Land Use}

\section{Forests Cover Most of the Area}

Forests cover about 80 percent of Area 15, followed by cropland and pastures.

The principal land use in Area 15 is forest, covering about 79 percent of the area (fig. 2.4-1 and table 2.4-1). The steep, hilly landscapes of the area generally are not suited for agricultural, industrial, or urban development. About 16 percent of Area 15 is within the Daniel Boone National Forest.

Land suitable for agriculture in Area 15 occurs in relatively small areas in narrow valleys or on narrow ridgetops. These areas, about 8 percent of the total, generally are not suited for extensive cropping and the narrow valleys are often subjected to flash flooding. Pastures, mostly in Jackson, Rockcastle, and
Whitley counties, comprise about 7 percent of the land use, often combined with other agricultural land.

The category for "other land" includes that used for farm roads, feed lots, rural and non-farm residences, strip mines and quarries and other minor uses. Land-use data are not available to differentiate between these uses, which account for about 3 percent of Area 15. Urban and built-up areas also account for about 3 percent of the area. 


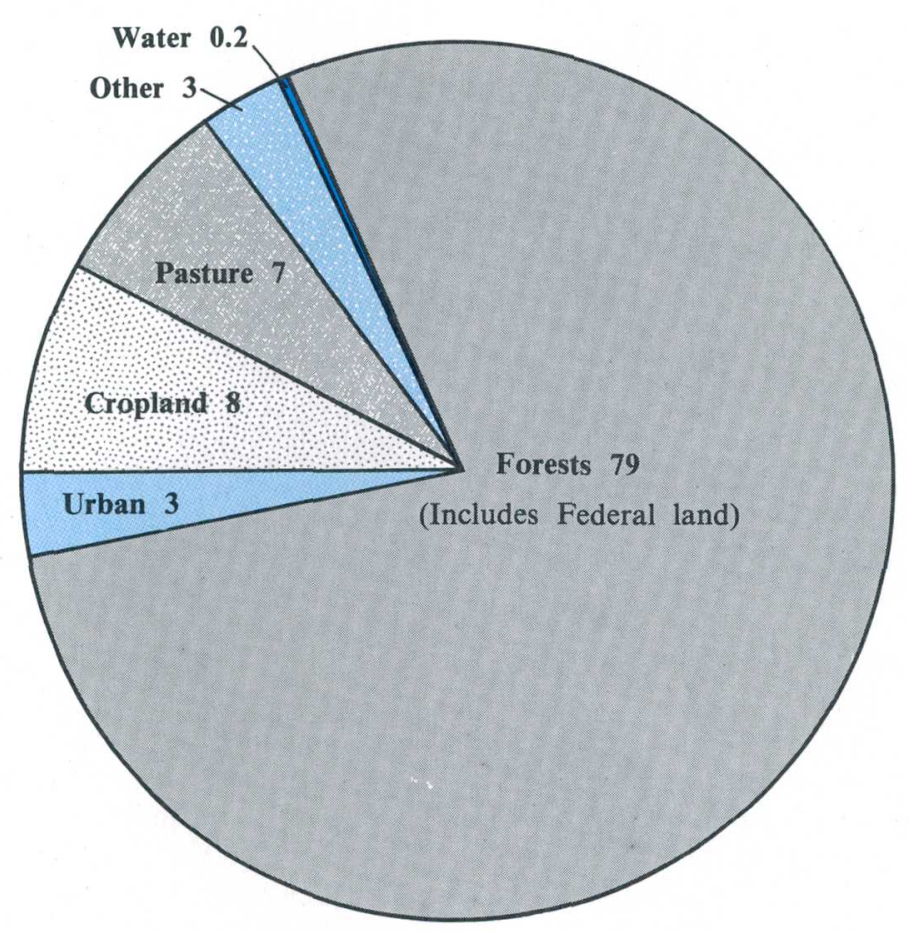

Figure 2.4-1 Percent of land uses.

Table 2.4-1 Land use in 1967.

\begin{tabular}{|c|c|c|c|c|c|c|c|c|}
\hline COUNTY & $\begin{array}{l}\text { TOTAL } \\
\text { LAND } \\
\text { AREA } 1\end{array}$ & $\begin{array}{l}\text { CROP- } \\
\text { LAND }\end{array}$ & PASTURE & FOREST & $\begin{array}{l}\text { OTHER } \\
\text { LAND } 2\end{array}$ & $\begin{array}{l}\text { FEDERALLY } \\
\text { OWNED NON- } \\
\text { CROPLAND } 3\end{array}$ & $\begin{array}{l}\text { URBAN } \\
\text { AND } \\
\text { BUILT-UP }\end{array}$ & $\begin{array}{l}\text { SMALL } \\
\text { WATER } \\
\text { AREAS }\end{array}$ \\
\hline BELL & 236 & 2.8 & $4 \cdot 1$ & 202 & $7 \cdot 3$ & 9.3 & 9.6 & .7 \\
\hline HARLAN & 300 & $4 \cdot 6$ & $2 \cdot 6$ & 261 & 19.1 & 1.4 & 10.7 & 1.2 \\
\hline JACKSON & 216 & 20.1 & $27 \cdot 6$ & 109 & 1.2 & 52.4 & $4 \cdot 3$ & .7 \\
\hline KNOX & 239 & $28 \cdot 3$ & $14 \cdot 3$ & 178 & 11.8 & 0.0 & 6.0 & .8 \\
\hline LAUREL & 285 & 62.2 & $18 \cdot 0$ & 141 & $8 \cdot 4$ & $46 \cdot 1$ & 9.6 & .2 \\
\hline MCCREARY & 268 & $5 \cdot 1$ & $8 \cdot 0$ & 93 & 2.9 & $157 \cdot 0$ & 1.7 & $\bullet 1$ \\
\hline ROCKCASTLE & 199 & 27.4 & 30.1 & 63 & 1.9 & 11.4 & 6.2 & $\cdot 3$ \\
\hline WHITLEY & 294 & 19.6 & 31.9 & 197 & $4 \cdot 4$ & 32.5 & 9.4 & .2 \\
\hline TOTALS 4 & 2037 & 169.1 & 136.6 & 1244 & 57.0 & 310.1 & 57.5 & 4.2 \\
\hline
\end{tabular}

1 INCLUDES TOTAL AREA OF COUNTY. DOES NOT INCLUDE TENNESSEE OR LETCHER COUNTY, KENTUCKY.

2 NON-FEDERALLY OWNED RURAL LAND NOT

CLASSIFIED AS CROPLAND, PASTURE, FOREST

WOODLAND, OR URBAN AND BUILT-UP AREA.
3 LAND USE STATUS NOT GIVEN IN SOURCE; CONSIDERED EY AUTHORS TO BE FOREST LAND IN DANIEL BOONE NATIONAL FOREST.

4 BECAUSE OF ROUNDING OFF, THE SUMS OF THE LAND USES DO NOT AGREE WITH THE TOTAL LAND AREA. 


\title{
2.0 GENERAL FEATURES--Continued \\ 2.5 Coal Production
}

\section{Coal Production in 1978 was about 22 Million Tons in Area 15}

\author{
In 1978, the principal coal production was from Harlan and Bell \\ Counties with a combined total of 14.7 million tons. Surface \\ mining production was about 52 percent of the total.
}

Coal production in Area 15 was about 22 million tons in 1978 of which about 52 percent was from surface mines. More than 67 percent of the production (14.7 million tons) was from mines in Harlan and Bell Counties in the upper Cumberland River basin (fig. 2.5-1). In Bell County, coal production data from 1950-78 show a steady increase in surface mining (fig. 2.5-2). However, in Harlan County, underground production is seven times surface mining production (fig. 2.5-3). This greater volume of under-ground mining is due in part to the topography of the upper Cumberland River basin which is more rugged in Harlan than in Bell County, and to deeper coal seams in the headwaters of the basin which make surface mining impractical or uneconomical. 


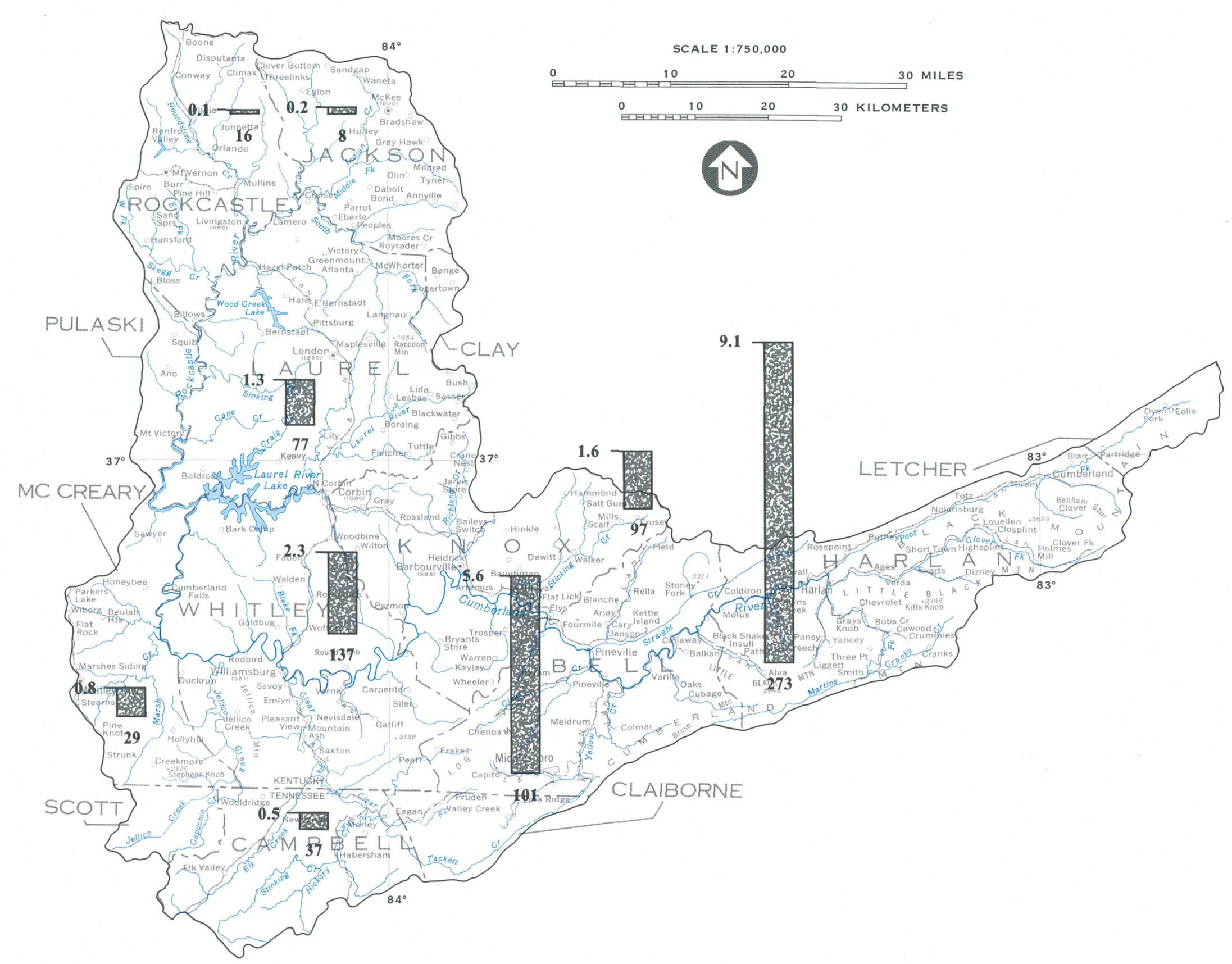

EASE FROM U. S. GEOLOGIIALL SURVEY
STAAE BASE MAP, 1973

EXPLANATION

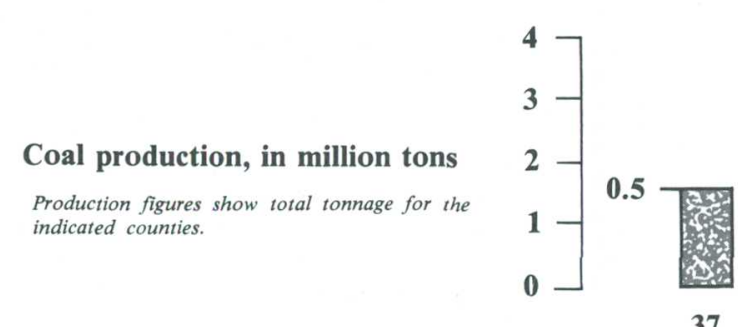

37 Number of surface and underground mines, undifferentiated

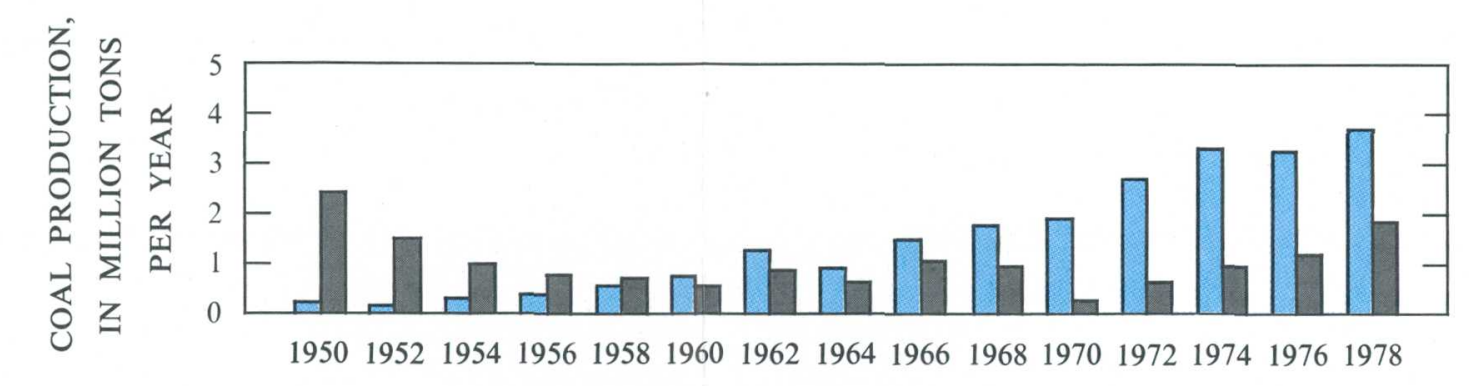

Figure 2.5-2 Coal production from underground and surface mines in Bell County, Kentucky, 1950-78.
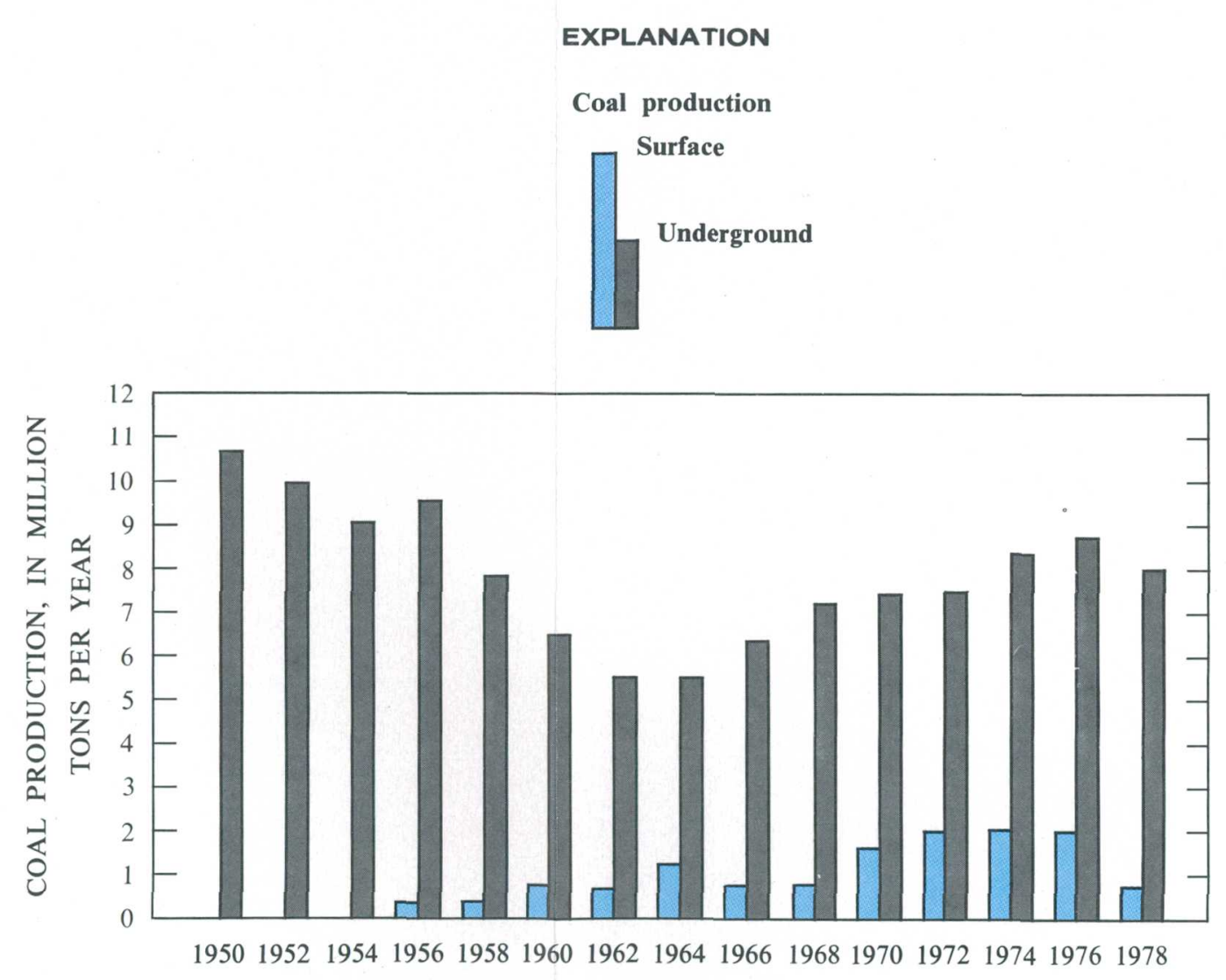

Figure 2.5-3 Coal production from underground and surface mines in Harlan County, Kentucky, 1950-78. 


\title{
2.0 GENERAL FEATURES--Continued 2.6 Soils
}

\section{Soils Originate from Sandstone, Siltstone and Shale}

\author{
The principal soil associations are groups of the Jefferson-Shelocta, \\ Lathan-Shelocta, and Shelocta-Gilpin.
}

Most of the soils in Area 15 are deep, welldrained, acidic soils of the Jefferson-Shelocta, Lathan-Shelocta and Shelocta-Gilpin associations (fig. 2.6-1) (Soil Conservation Service, 1974 and 1978).

The predominant association in the Cumberland River basin is the Shelocta-Gilpin. These are moderately deep to deep, well-drained soils formed in loamy colluvium from acid siltstones, shales, and sandstones (table 2.6-1). They occupy the long-steep side slopes of the higher ridges of the Cumberland River basin in the Cumberland Mountains. Slopes range from 20 to 60 percent.

Soils along the northern edge of the Cumberland River basin in Bell and Knox counties, and in most of the Laurel River basin, are associations of the Lathan-Shelocta group. These are moderately deep to deep, well-drained soils formed in clayey residium of acid shales and loamy colluvium. The slopes range from 20 to 50 percent. The steepness of the mountainous terrain where these soils occur makes them unsuitable for most agricultural uses. These slopes are mostly woodland, with some pasture.

Most of the Rockcastle River basin includes the soils of the Jefferson-Shelocta association. A large band of these soils is also present in the northern Cumberland River basin, in Knox and Bell counties. These are also deep to moderately deep, well-drained soils. They are formed in loamy colluvium from shales, sandstones and siltstones. The area where these soils are found is covered with forest. Steep slopes (20 to 60 percent) also make these soils poorly suited for agriculture.

Toward the center of Area 15 there is a band of several mixed soils, mostly of alluvial origin. These are formed on terraces and floodplains along the lower Cumberland River in Knox and Whitley counties. These are the best agricultural soils but are subject to periodic flooding from the Cumberland River.

Two narrow bands of the Jefferson-Dekalb soils run from east to west along Pine and Cumberland Moutains. The soils are very similar to those in the Rockcastle River basin (Jefferson-Shelocta).

The soils in the Tennessee part of Area 15 are similar to the Shelocta-Gilpin and Lathan-Shelocta groups. Tennessee classifications list them as part of the Muskingum-Gilpin-Jefferson associations (Soil Conservation Service, 1978)(table 2.6-1). 


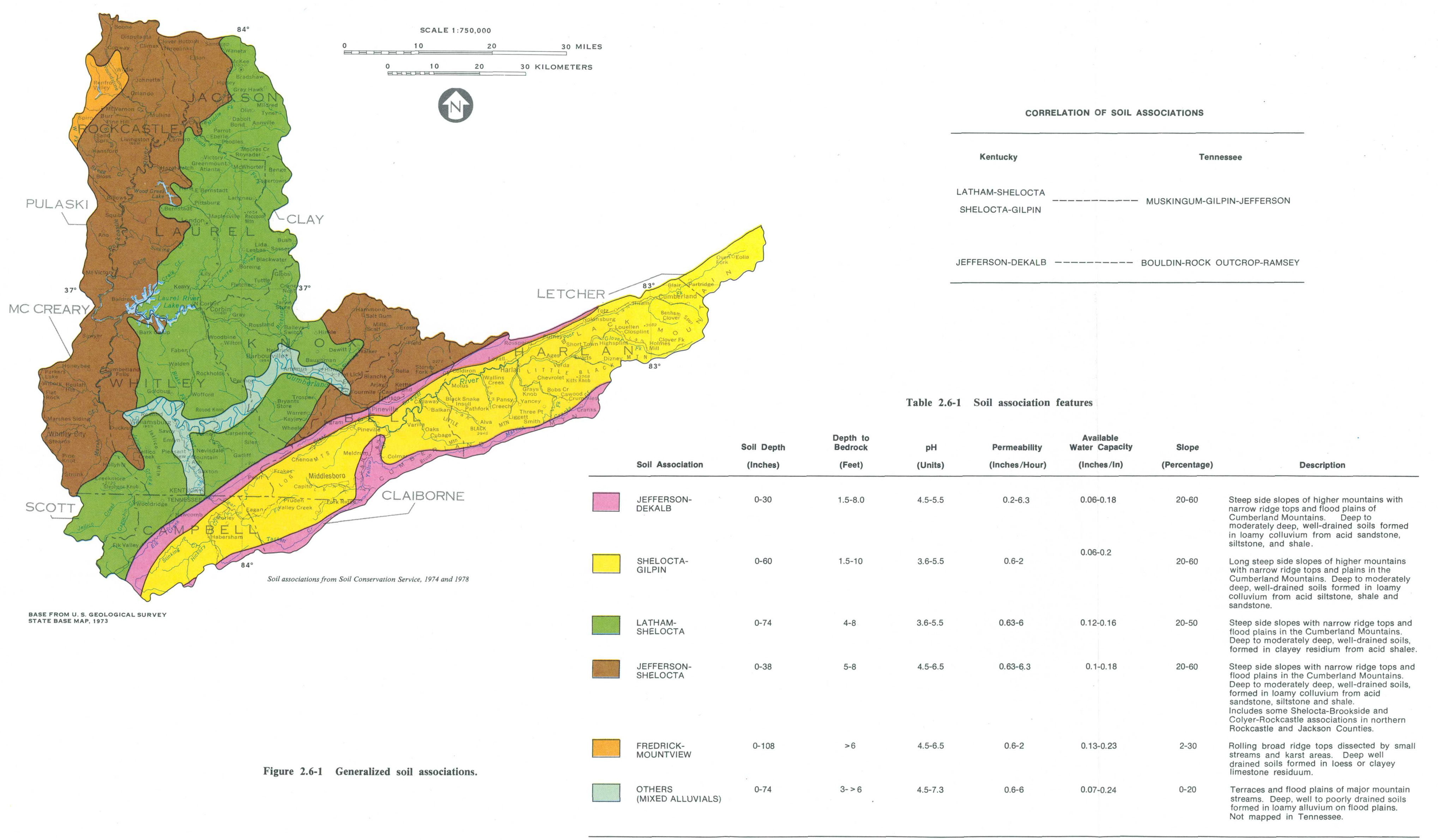




\subsection{GENERAL FEAT TURES--Continued \\ 2.7 Precipitation}

\section{Precipitation Averages about 46 to 55 Inches and Occurs 110 to 130 Days Per Year}

\section{March and July average rainfall is greater than other months; September and October average rainfall is least.}

The average precipitation from 1951 to 1978 at nine precipitation measuring stations in Area 15 ranges from about 46 to 55 inches per year (fig. 2.7-1). Length of station records range from 16 to 27 years. Measurable precipitation occurs 110 to 130 days per year. During an average year, most rainfall at Williamsburg, Ky. (Whitley County) occurs during March and July, while the least occurs in September and October (fig. 2.7-2).

Extreme storms with rainfall averaging about 4.5 inches in a 24-hour period have a recurrence interval of 10 years (fig. 2.7-3). The upper Cumberland River basin is subject to very intense local storms. The most recent intense storm was during 1978, with 24-hour rainfalls of as much as 4.4 inches, and a three day rainfall total of 6.0 inches. Rainfalls of this intensity generally cause flash floods, landslides, and heavy sediment runoff.

Snow and sleet are not a significant part of the precipitation. They average about 20 inches per year which is equal to about two inches of rainfall. However, during extreme years, snow totals of more than 50 inches can contribute significantly to the spring runoff. 


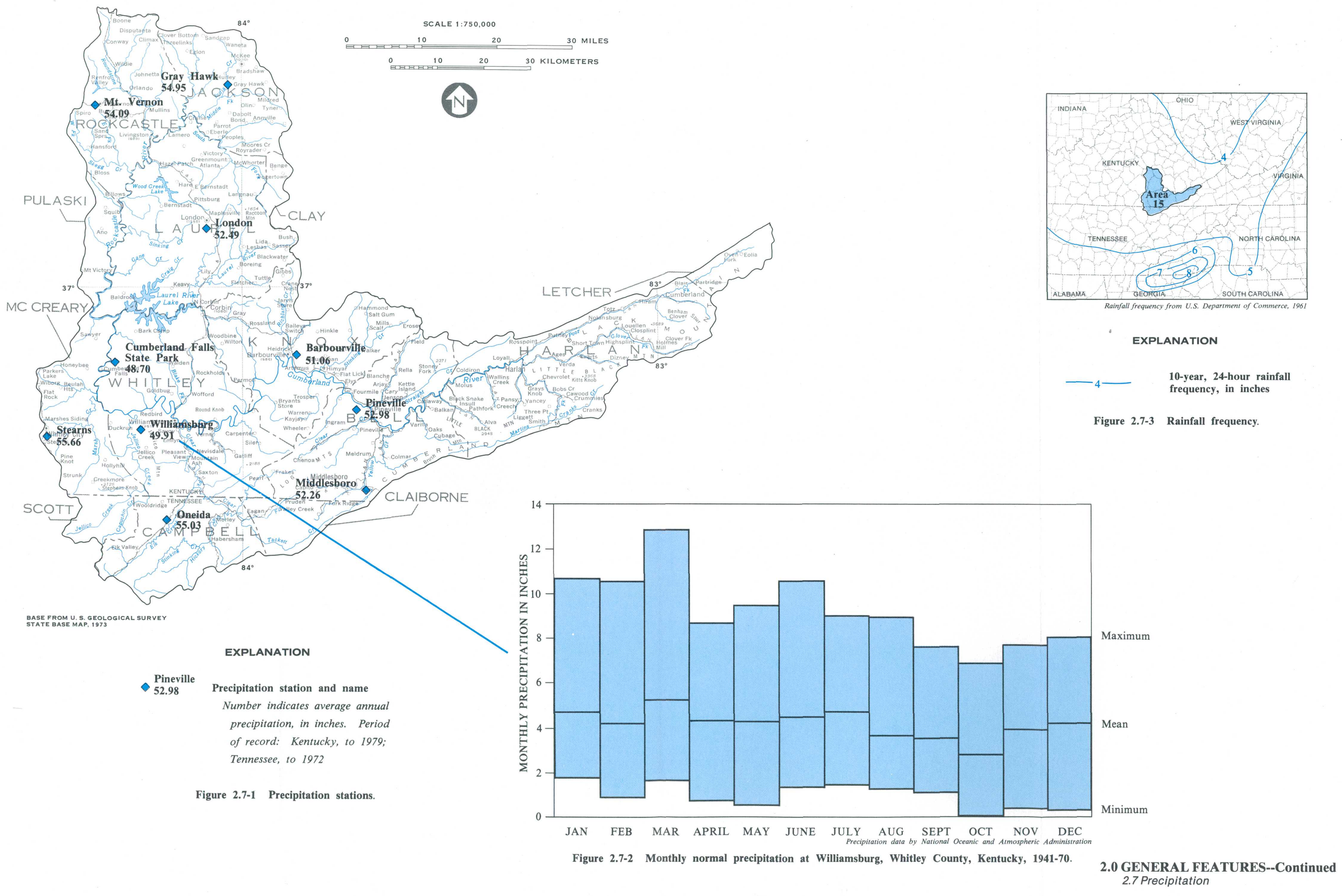




\subsection{WATER USE}

\section{Principal Water Use is for Domestic Supply}

\section{About 12.9 million gallons per day was withdrawn in 1975 for domestic, industrial, and agricultural uses. Water is also used extensively for recreation.}

Water use in Area 15 during 1975 was about 12.9 $\mathrm{Mgal} /$ day. Water use data by county are presented in figure 3.0-1. About 84 percent of the water used (10.8 Mgal/d) was for public supply, mainly for domestic use (fig. 3.0-2). Surface water is the primary source of supplies, accounting for about 80 percent of the water withdrawn.
Recreation is an important water use in Area 15. The upper Cumberland River basin is considered one of the most important fishing areas in the state. About 1,040 miles of streams are considered of fishery importance (Carter and Jones, 1969). Many streams have a wide variety of game fish. 

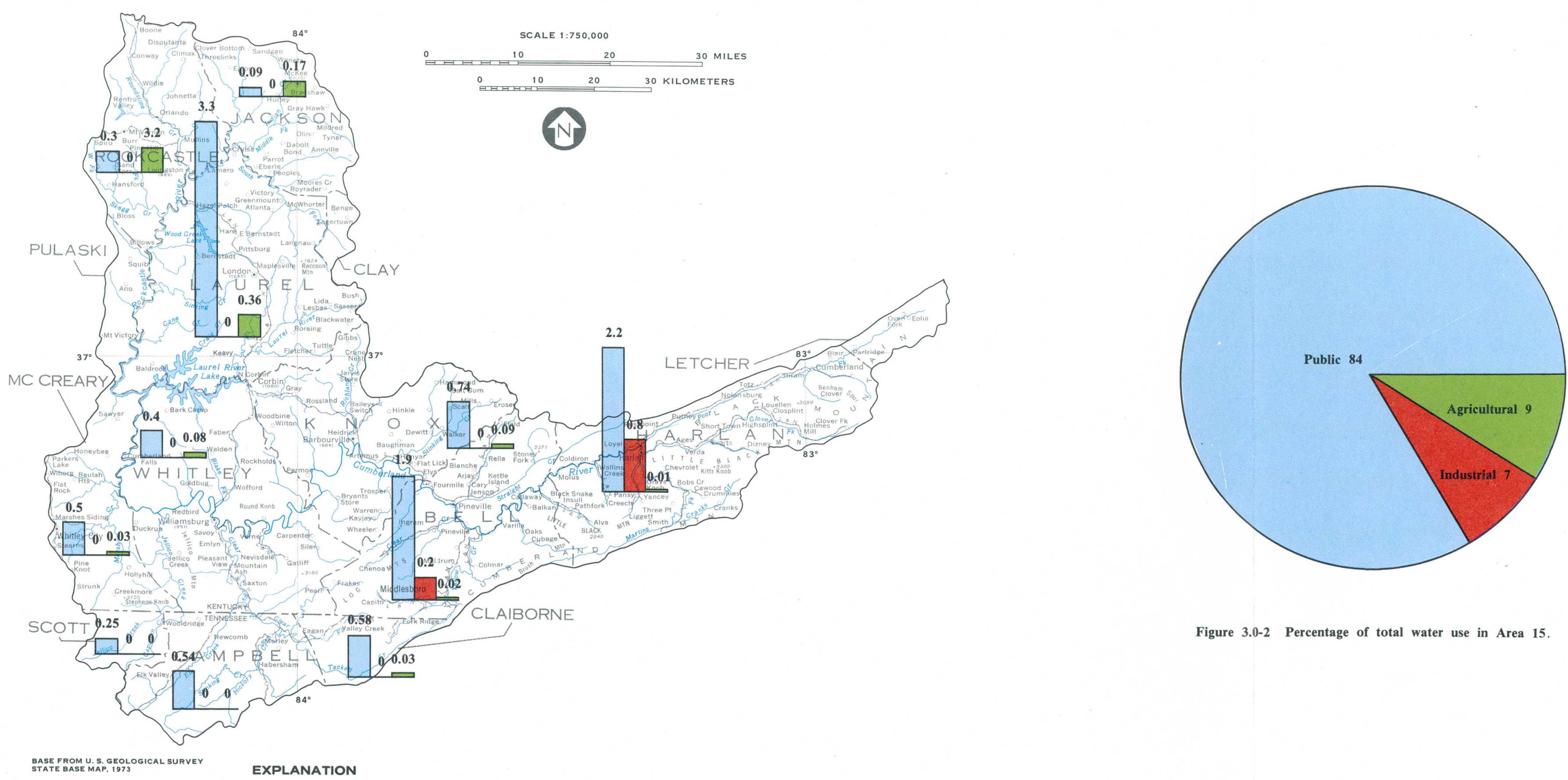

Figure 3.0-2 Percentage of total water use in Area 15

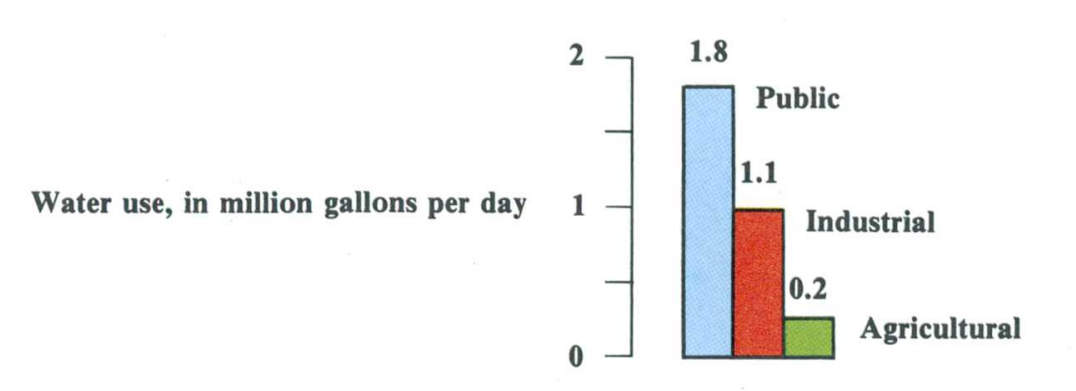

Figure 3.0-1 Water use in 1975, by county. 


\title{
4.0 HYDROLOGIC DATA 4.1 Surface Water
}

\section{Information on Surface Water Available for 86 Sites}

\author{
Surface-water data-collection sites in Area 15 were expanded from 30 to 59 \\ sites in 1979 by the U.S. Geological Survey in response to the Surface Mining \\ Control and Reclamation Act. Data are also available for 27 inactive sites.
}

At the time of the passage of the Act there were 12 active continuously recording surface-water gaging stations and 18 non-recording sites on streams in Area 15. One continuosly-recording site and 28 non-recording sites were added in 1979 . In addition, one non-recording site was started in 1979 but discontinued in the same year. The continuouslyrecording gaging stations record stream stage with time. These data can, in turn, be converted to stream discharge after each station is rated or calibrated. Thus continuous-recording stations, as shown on figure 4.1-1 and in section 10.2, are sites where a continuous record of stream stage and flow is recorded. The non-recording stations are on small streams where streamflow measurements are made several times annually (fig. 4.1-1 and section 10.2).

Records of stream stage and flow are valuable data used in analyzing the hydrology of basins and for planning structures and water uses of streams. Various data-analysis techniques, such as flow-duration curves, flood-frequency relations, and low-flow analyses (to be presented in subsequent sections) rely on a record of stage and discharge relation with time.

In addition to the active continuously recording sites, two discontinued recording sites and 25 discontinued non-recording sites are also shown (fig. 4.1-1 and section 10.2).

The historical data, as well as data on active sites, are published in the annual reports "Water
Resources Data for Kentucky" and "Water Resources Data for Tennesee". The information is also readily available through the National Water Data Exchange (NAWDEX) as described in Section 9.0.

Surface-water quality data are valuable and needed along with flow data to assess existing conditions and changes that may result from mining and reclamation practices as well as other land uses.

Very little surface-water quality data were available area-wide prior to 1979 when the number of water-quality sites was expanded, as shown in section 10.2. This expansion of data-collection sites occured in two ways; collection on a regular six-week interval of water quality data at selected continuously recording sites, and collection of water-quality data at sites on streams where streamflow was not continuously recorded. At these latter sites, generally on smaller streams, streamflow was measured and water samples were collected for selected physical and chemical analysis at approximately three-month intervals in order to measure seasonal quality and quantity variations. All water quality sample collecting was done as simultaneously as possible to provide areawide water-quality data during a particular flow condition. Surface-water quality data are available from the previously mentioned "Water Resources Data" reports for Kentucky and Tennessee or from NAWDEX. 


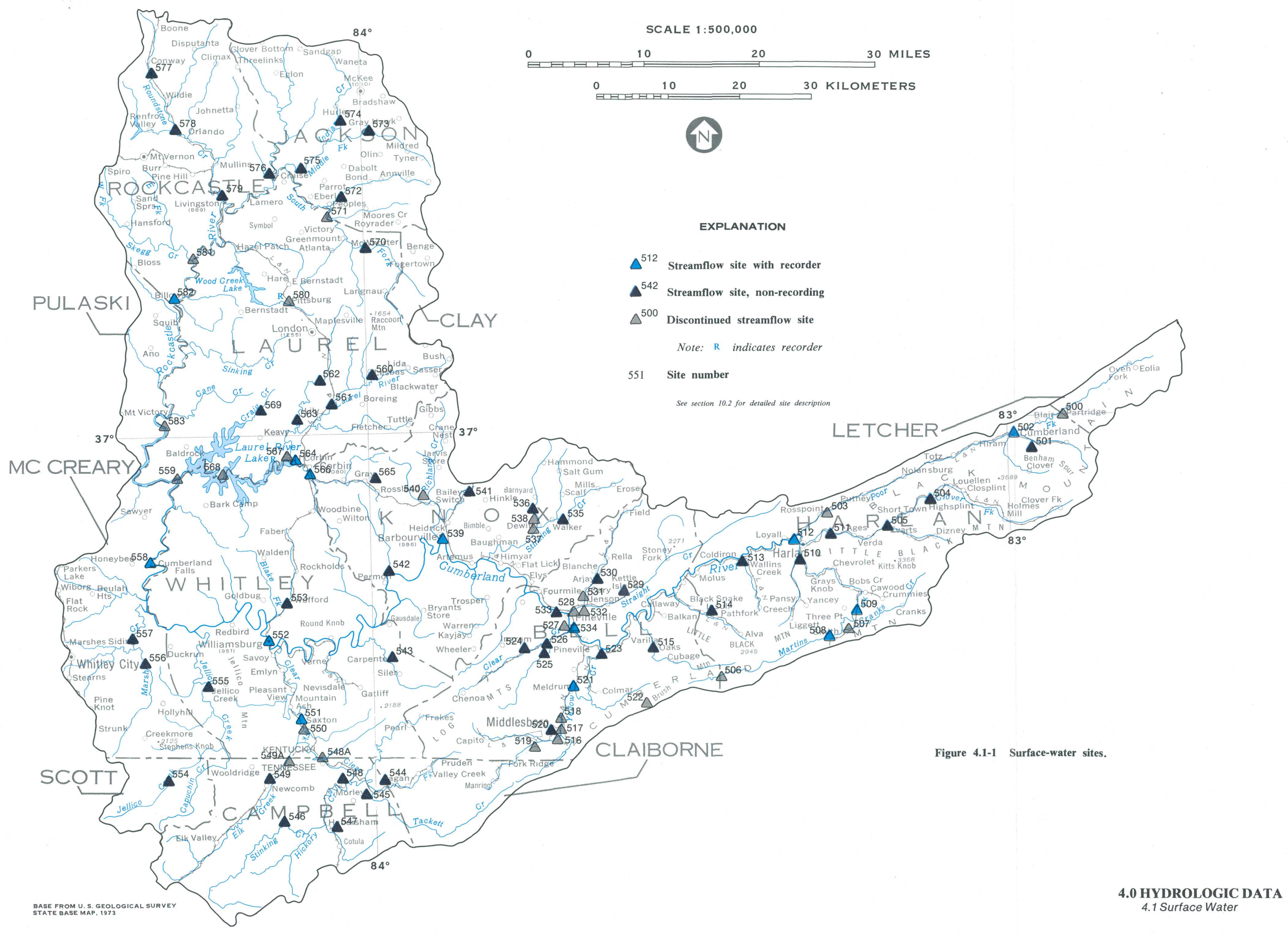




\title{
4.0 HYDROLOGIC DATA--Continued \\ 4.2 Ground Water
}

\section{Four Reports Describe Ground-Water Hydrology of the Area}

\author{
Chemical analyses of ground water are available for most of Area \\ 15. Three wells monitor ground-water levels and one well \\ monitors ground-water quality.
}

Surface mining and other land disturbances can alter the quality and quantity of ground-water. Data on ground-water availability and quality have been published in reports that include all of Area 15 (fig. 4.2-1). The reports, all of a reconnaissance nature, show depth of wells, reported or measured water levels, yields of wells, reported or analyzed quality of ground water, data on chemical analysis of ground water, and contain a general discussion on the ground-water hydrology of the report area.

The locations of wells for which chemical analyses of water are available are shown on figure 4.2-2 and in section 10.3. Data from these analyses were used in the summary of ground-water quality in Section 8.0.

Long-term water-level information is currently available from 3 wells in the area (fig. 4.2-1). These wells provide information on the artesian and watertable aquifers. One well tapping the Lee Formation in Bell County has been sampled periodically for chemical and physical analyses since 1964; annual samples have been collected since 1969. Data on these wells are listed below.
A comprehensive study of the hydrogeology of the Eastern Coal Field region in Kentucky was begun in 1980 by the Kentucky Geological Survey. The study, which includes Area 15, will gather additional data on the aquifers in the area, will develop a data base to supplement the present ground-water monitoring program, and will establish a network of observation wells.

The ground-water data collected during 1980 , as well as historical data, are published in the annual report "Water Resources Data for Kentucky". The information is also readily available through the National Water Data Exchange (NAWDEX) as described in section 9.0.

$\begin{array}{cccccc}\begin{array}{c}\text { Site } \\ \text { number }\end{array} & \begin{array}{c}\text { Site } \\ \text { identification } \\ \text { number }\end{array} & \begin{array}{c}\text { Ground-water monitoring sites } \\ \text { Depth of } \\ \text { well, } \\ \text { in feet }\end{array} & \begin{array}{c}\text { Formation } \\ \text { tapped }\end{array} & \begin{array}{c}\text { Period of } \\ \text { record }\end{array} & \begin{array}{c}\text { Frequency } \\ \text { of } \\ \text { measurement }\end{array} \\ 1 & 370757084045001 & 370 & \text { Lee } & \begin{array}{c}1951-62 \\ 1965-\end{array} & \text { R } \\ 2 & 363730083423501 & 940 & \text { Lee } & \begin{array}{c}1964, \\ 1966-67,\end{array} & \text { P, Q } \\ & & & & \text { Breathitt } & 1969- \\ 1 & & & \text { Lee } & 1964- & \text { R } \\ 4 & 363749083430701 & 39 & & \text { R }\end{array}$

1 P - Periodic, R - Recorded, Q - Water quality 


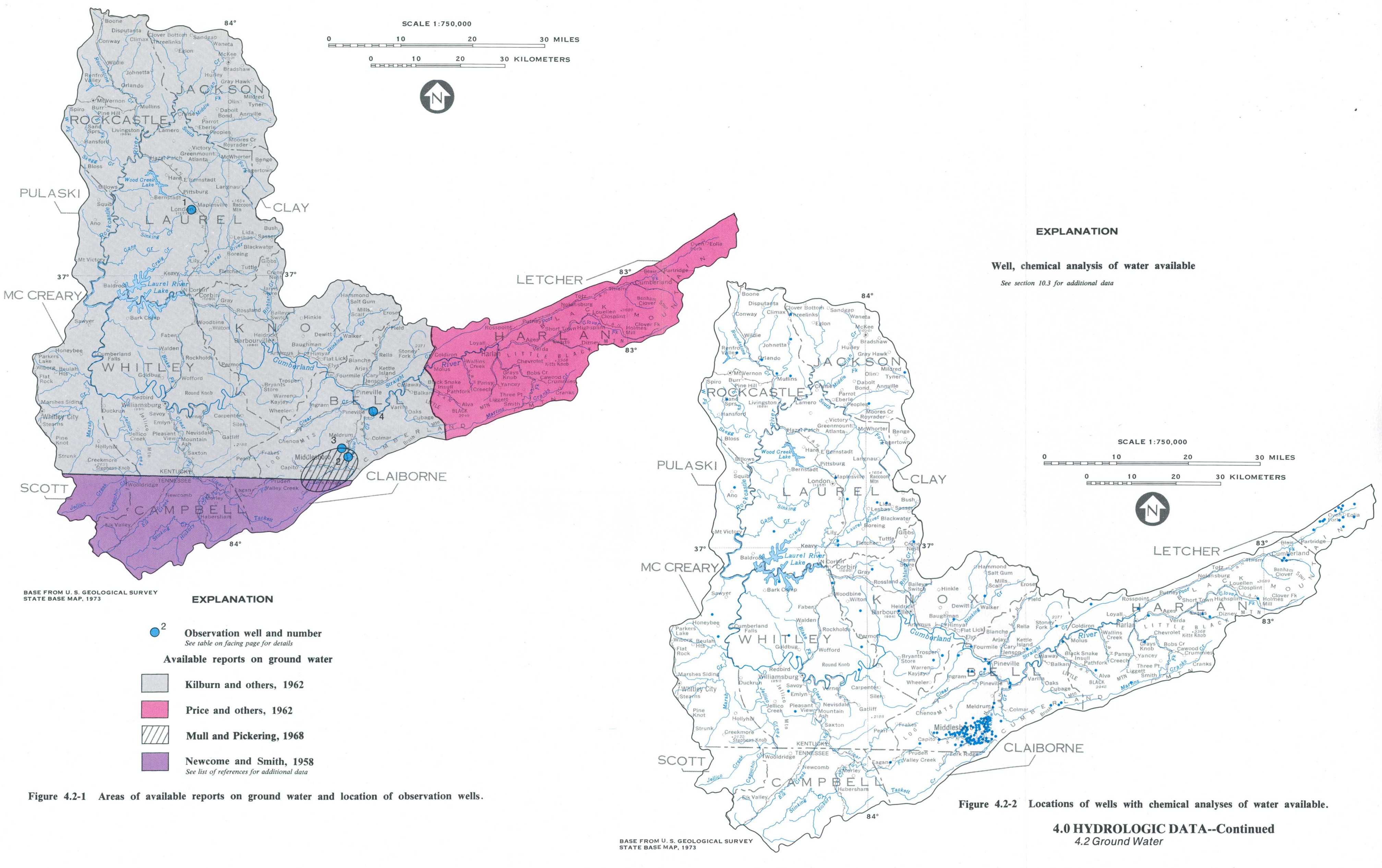




\title{
5.0 SURFACE WATER \\ 5.1 Streamflow Characteristics
}

\section{Streamflow Varies Seasonally and Geographically}

\author{
Streamflow fluctuates seasonally with precipitation and evapotranspiration. \\ Runoff at sites in the Cumberland River basin averages about 25.6 inches per \\ year, while in the Rockcastle River basin, the average is about 19.4 \\ inches per year.
}

Streamflow throughout Area 15 varies seasonally with precipitation and evapotranspiration. The yearly cycle of streamflow is considered to begin in October, normally the month of least precipitation and lowest streamflows (fig. 5.1-1 to fig. 5.1-3). Streamflow at sites in the area generally increase during November as precipitation increases and evapotranspiration decreases. Increasing precipitation both as rain or snow augments flows through the winter months. Spring thunderstorms help to maintain a relatively high runoff through May. The lowflow season generally begins around June, as precipitation decreases and evapotranspiration increases, and extends through late October or early November. Summer thunderstorms temporarily reverse the trend of low streamflow during this season.
Average runoff at streamflow sites in the area ranges from 18.6 to $35.3 \mathrm{in} / \mathrm{yr}$ (Table 5.1-1, below). In general, runoff is several inches higher at sites in the Cumberland River basin (mined) than in the Rockcastle River basin (partially mined). Rainfall in Area 15 is fairly uniform, ranging from about 46 to $55 \mathrm{in} / \mathrm{yr}$. At most of the sites in the Cumberland River basin, runoff of about $25.6 \mathrm{in} / \mathrm{yr}$ is about 50 percent of precipitation. In comparison, at the sites in the Rockcastle River basin, runoff of about 19.9 in/yr is about 40 percent of precipitation. Physiographic, cultural, and geologic differences probably account for part of the excess runoff at sites on the Cumberland River. The effect of surface-mining in the basin on average runoff is unknown.

Table 5.1-1 Average runoff.

$\begin{array}{lccc}\begin{array}{l}\text { SITE } \\ \text { NUMBER }\end{array} & \text { BASIN } & \begin{array}{c}\text { YEARS OF } \\ \text { RECORD }\end{array} & \begin{array}{c}\text { INCHES PER } \\ \text { YEAR }\end{array} \\ 502 & & & \\ 509 & \text { CUMBERLAND } & 39 & 23.9 \\ 512 & " & 8 & 35.3 \\ 521 & " & 39 & 25.4 \\ 534 & " & 39 & 25.8 \\ 539 & " & 37 & 23.7 \\ 551 & " & 40 & 25.3 \\ 552 & " & 11 & 25.6 \\ 558 & " & 29 & 23.6 \\ 564 & \text { " } & 69 & 22.1 \\ 566 & \text { " } & 6 & 27.6 \\ 567 & \text { " } & 6 & 25.0 \\ 580 & \text { ROCKCASTLE } & 33 & 22.8 \\ 582 & \text { " } & 18 & 18.6 \\ & & 43 & 21.2\end{array}$




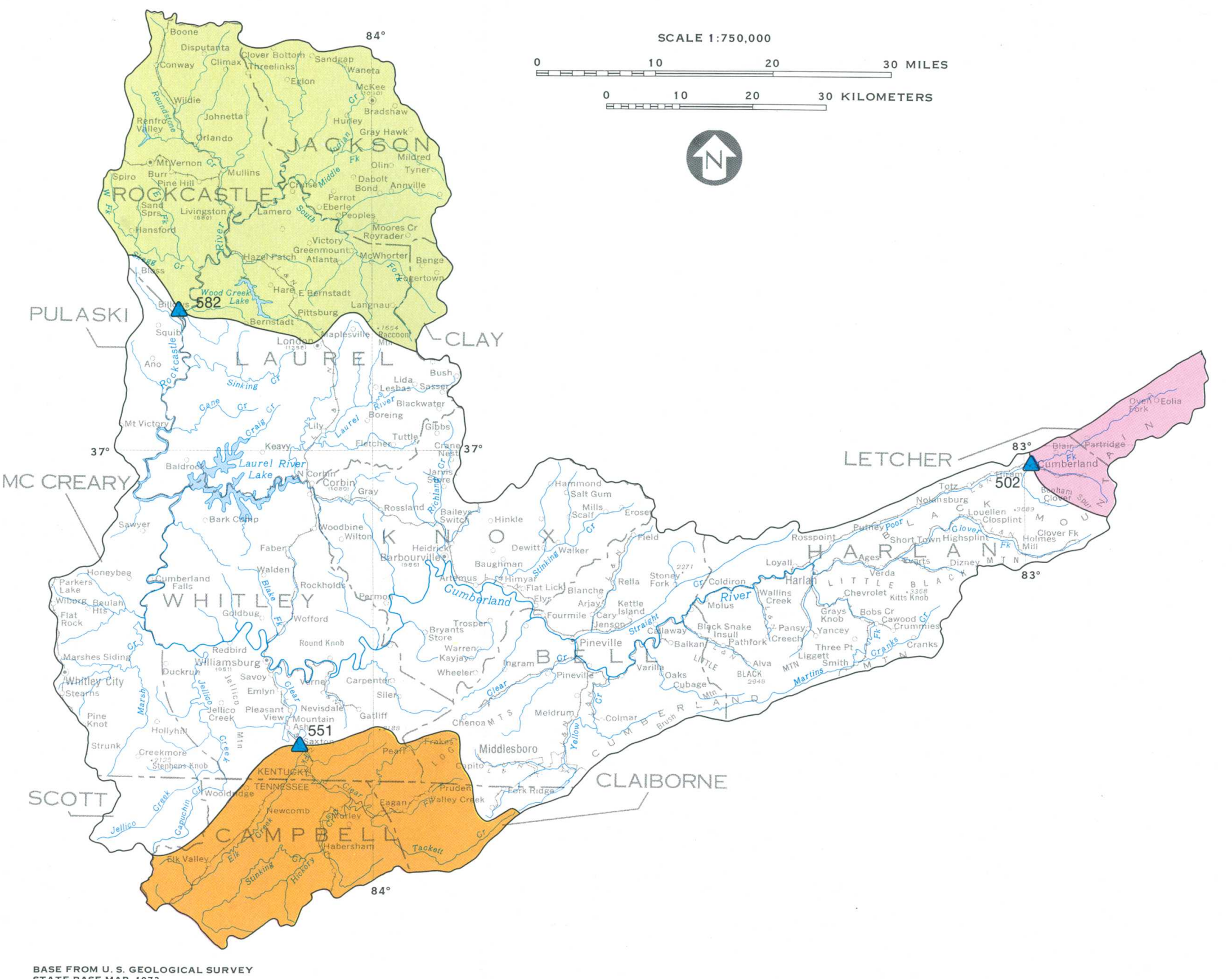

EXPLANATION

$\Delta^{551}$ Site location and number

Drainage basin of Rockcastle River at Billow (site 582)

Drainage basin of Clear Fork near Saxton (site 551)

Drainage basin of Poor Fork near Cumberland (site 502)

See section 10.2 for detailed site description

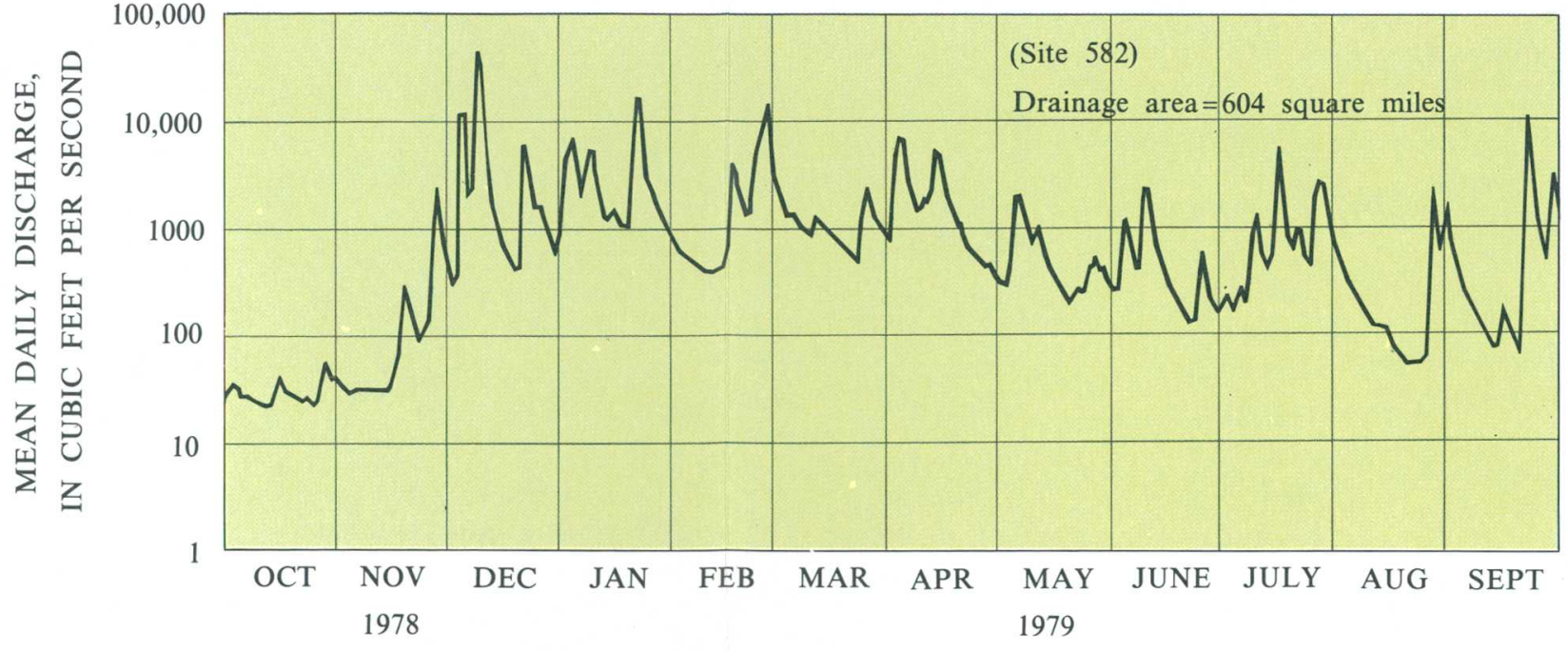

Figure 5.1-1 Mean daily discharge for Rockcastle River at Billows, Kentucky, 1979 water year.
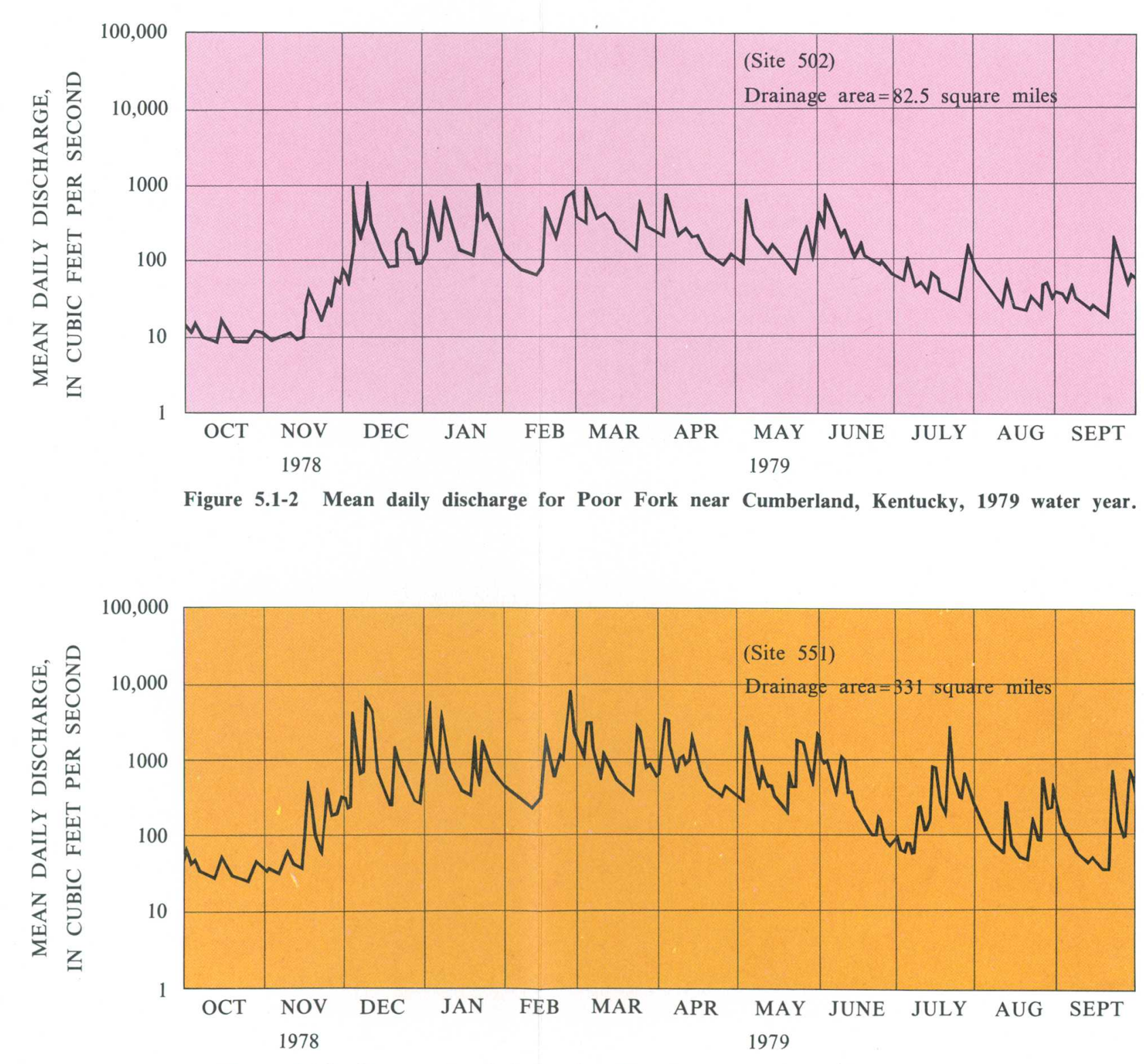

Figure 5.1-3 Mean daily discharge for Clear Fork at Saxton, Kentucky, 1979 water year. 5.0 SURFACE WATER 5.1 Streamflow Characteristic 


\title{
5.0 SURFACE WATER--Continued \\ 5.2 Low Flow
}

\section{Most Streams Draining Less Than 100 Square Miles Dry Up Occasionally}

\author{
Many sites draining less than 100 square miles have 7 day-10 year \\ minimum flows of zero.
}

The steep slopes of the area cause rapid surface runoff that coupled with the semi-impervious nature of the soils limits the infiltration of precipitation to aquifers. As a result, there is not sufficient ground water in storage to sustain sizable or prolonged base flows in streams. Therefore, during the low-flow season, from about July through August, many of the small streams draining less than $100 \mathrm{mi}^{2}$ become dry.

A network of low-flow sites has been operated throughout the area for many years. Data on low- flow measurements of streamflow at non-recording sites are compared with data from recording sites (index stations) to estimate low flow at the nonrecording sites. Data from the low-flow sites in Area 15 are presented in figure 5.2-1 and table 5.2-1. Results of the frequency analyses and calibration of non-recording sites were published in 1974 and 1980 (Swisshelm, 1974 ; Sullavan, 1980). Data about additional sites may be obtained from the U.S. Geological Survey District Office in Louisville. 


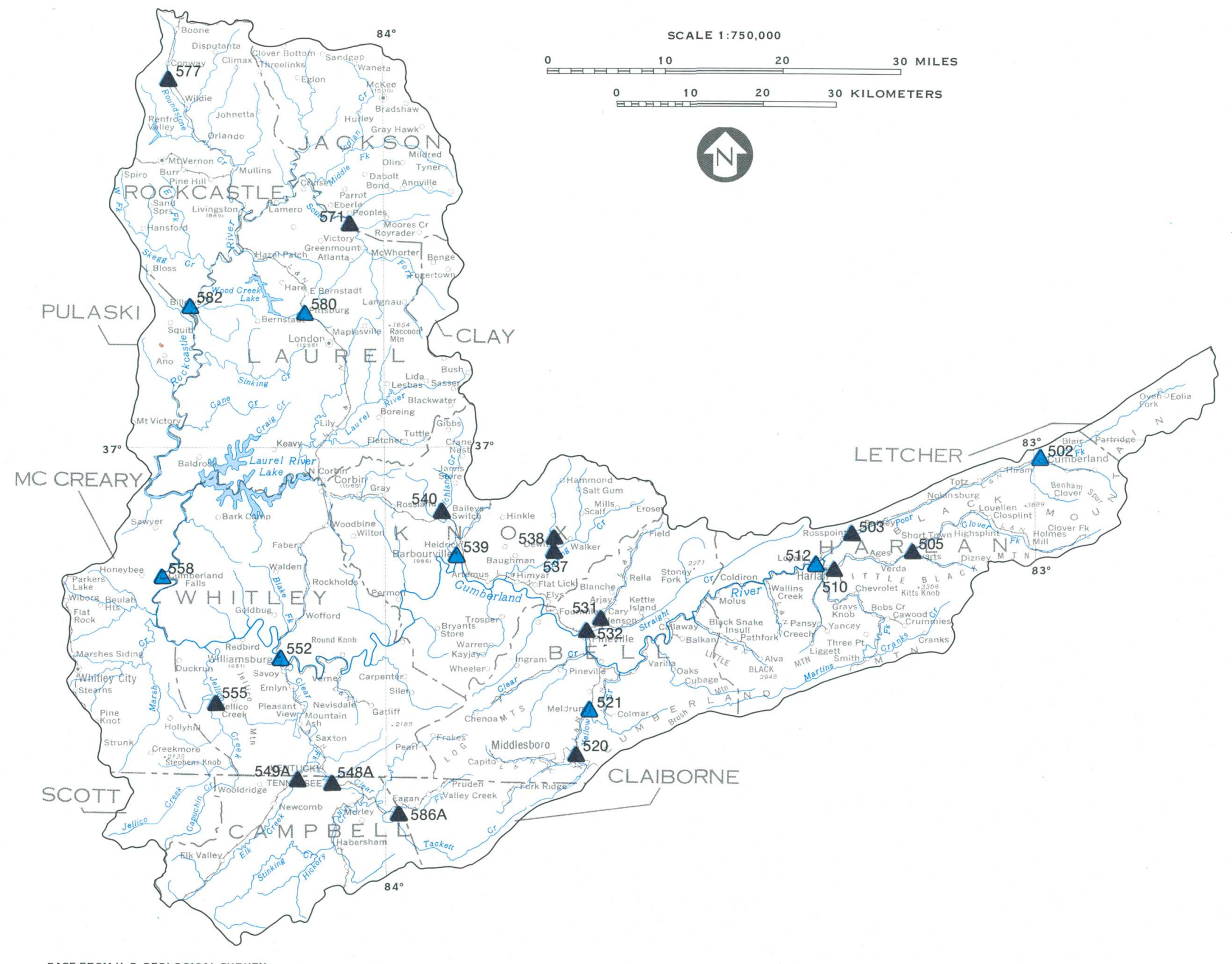

BASE RROMU.S. SEOLOLGICAL SURVEV
STATE BASE MAP, 1973
Table 5.2-1 7-day, 2-year and 7-day, 10-year low flows.

$\begin{array}{lccc}\text { SITE } & \text { DRAINAGE } & \text { 7-DAY 2-YEAR } & \text { 7-DAY 10-YEAR } \\ \text { NUMBER } & \text { AREA } & \text { DISCHARGE } & \text { DISCHARGE } \\ & \left(\mathrm{mi}^{2}\right) & \left(\mathrm{ft}^{3} / \mathrm{s}\right) & \left(\mathrm{ft}^{3} / \mathrm{s}\right)\end{array}$

\begin{tabular}{rcrr}
\hline & & & \\
502 & 82.3 & 8.9 & \\
503 & 142 & 10.0 & 4.2 \\
505 & 82.4 & 4.8 & 4.0 \\
510 & 116 & 8.0 & 1.8 \\
512 & 374 & 28.0 & 3.3 \\
520 & 35.3 & 0.5 & 11.0 \\
521 & 60.6 & 4.6 & 0.1 \\
531 & 33.7 & 0.5 & 2.3 \\
532 & 89.8 & 2.2 & 0.1 \\
537 & 49.1 & 0.1 & 0.6 \\
538 & 25.2 & 0.0 & 0.0 \\
539 & 960 & 50.0 & 0.0 \\
540 & 27.7 & 0.0 & 13.0 \\
$548 A$ & 240 & 1.5 & 0.0 \\
$549 A$ & 51.1 & 0.8 & 0.4 \\
552 & 1607 & 74.0 & 0.2 \\
555 & 103 & 0.1 & 18.0 \\
558 & 1977 & 74.0 & 0.0 \\
571 & 95.1 & 0.2 & 20.0 \\
579 & 144 & 0.0 & 0.0 \\
580 & 3.8 & 0.4 & 0.0 \\
582 & 604 & 11.0 & 0.3 \\
& & & 3.0 \\
\hline
\end{tabular}

See section 10.2 for deeailed site description

\section{EXPLANATION}

$\triangle$ Recording streamflow (index) site

A Non-recording site

$580 \quad$ Site number 


\subsection{SURFACE WATER--Continued \\ 5.3 Flood Flows}

\section{Flooding Severe in Area 15}

\section{Intense precipitation and topographic factors produce severe flooding throughout the area. Floods are usually of short duration.}

\begin{abstract}
Severe flooding occurs throughout Area 15 in response to intense precipitation and topographic factors. Intense storms, generated from moistureladen low-pressure systems from the southwest, occur frequently. The area has steep slopes and short narrow basins, which causes a short runoff traveltime from the headwaters to the lower parts of the area. In most of the smaller basins, floods are of short duration but high magnitude, flash flooding commonly occurs.
\end{abstract}

Peak discharge and rainfall data have been col- lected at 12 sites in Area 15 over the last 50 years. Peak discharges at gaging stations range from 30 to $193\left[\left(\mathrm{ft}^{3} / \mathrm{s}\right) / \mathrm{mi}^{2}\right]$. Runoff and precipitation comparisons at sites on streams with different drainage areas show that streamflows increase rapidly in response to precipitation (figures 5.3-1 and 5.3-2). Flood-data for the December 1978 flood shown in figures 5.3-1 and 5.3-2 represent flood discharges of less than two years recurrence interval. Typically the streams recede to their previous flow conditions within several days after the peak. 

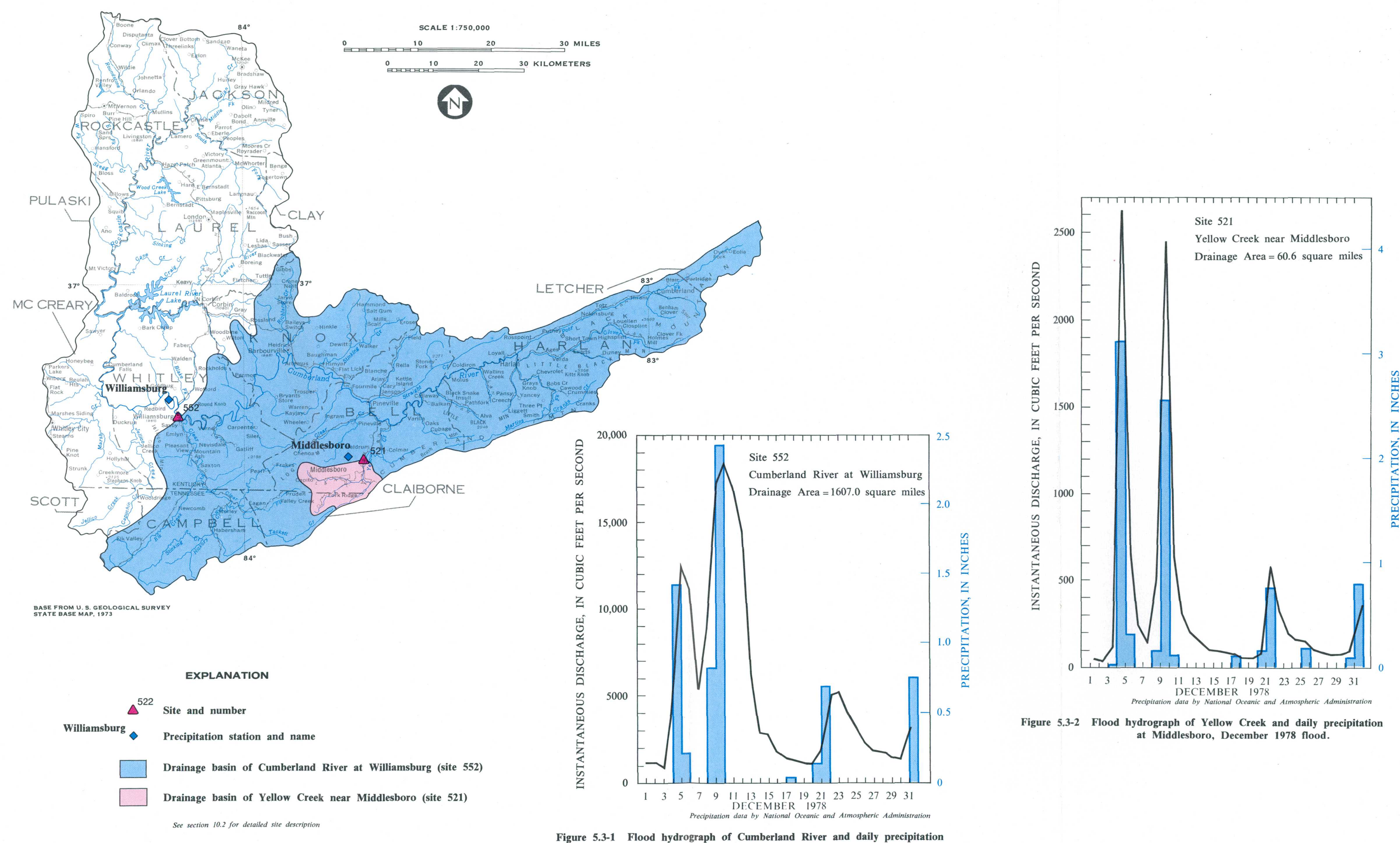

Figure 5.3-2 Flood hydrograph of Yellow Creek and daily precipitation 


\author{
5.0 SURFACE WATER--Continued \\ 5.4 Magnitude and Frequency of Floods
}

\title{
Floods Vary with Drainage Area, Topograpiny and Geology
}

\section{Differences in geography contribute to the magnitude and frequency of floods in Area 15. Several techniques are available to estimate the magnitude and frequency of floods.}

Flood-frequency analysis is important for the design of structures in flood plains. The frequency of flooding is expressed as a probability of occurrence, or recurrence interval. For example, the 50-year flood $\left(Q_{50}\right)$ could be expected, on the average, to occur once in 50 years. The 50-year recurrence-interval flood means that during any given year there is a 0.02 probability (two percent chance) that a flood of similar magnitude will be equalled or exceeded. Techniques for estimating magnitude and frequency of floods at gaged and ungaged sites throughout Kentucky have been developed by McCabe (1962) and Hannum (1976), and in Tennessee by Randolph and Gamble (1976).

Hannum developed generalized regression equations from which estimates at any site in Kentucky can be made. For the 50-year flood, the following equation applies:

$$
Q_{50}=638 \times A^{0.663} \times R^{1.040}
$$

where:

$$
\begin{aligned}
& \mathrm{Q}_{50}=\text { discharge of } 50 \text {-year flood in } \mathrm{ft}^{3} / \mathrm{s} \text {, } \\
& \mathrm{A}=\text { drainage area, in square miles }
\end{aligned}
$$

$\mathbf{R}$ is a geographical factor related to the geology and topography. $R$ values for Area 15 are from 1.417 in the headwaters of the Rockcastle River, 1.271 in the headwaters of the Cumberland River, and 0.805 farther downstream.

Graphical solutions to the equations defining the three geographical divisions of Kentucky in Area 15 (fig. 5.4-1) are shown in figures 5.4-2 to 5.4-4. Equations defining other flood frequencies are described by Hannum (1976).

Tennessee has been divided into four hydrographic areas by Randolph and Gamble (1976). Area 15 is in hydrographic Area 2. Graphic solutions to the equations for the hydrographic Area 2 of Tennessee are shown in figure 5.4-5. They developed generalized regression equations similar to Hannum (1976) that do not use a geographical factor. 

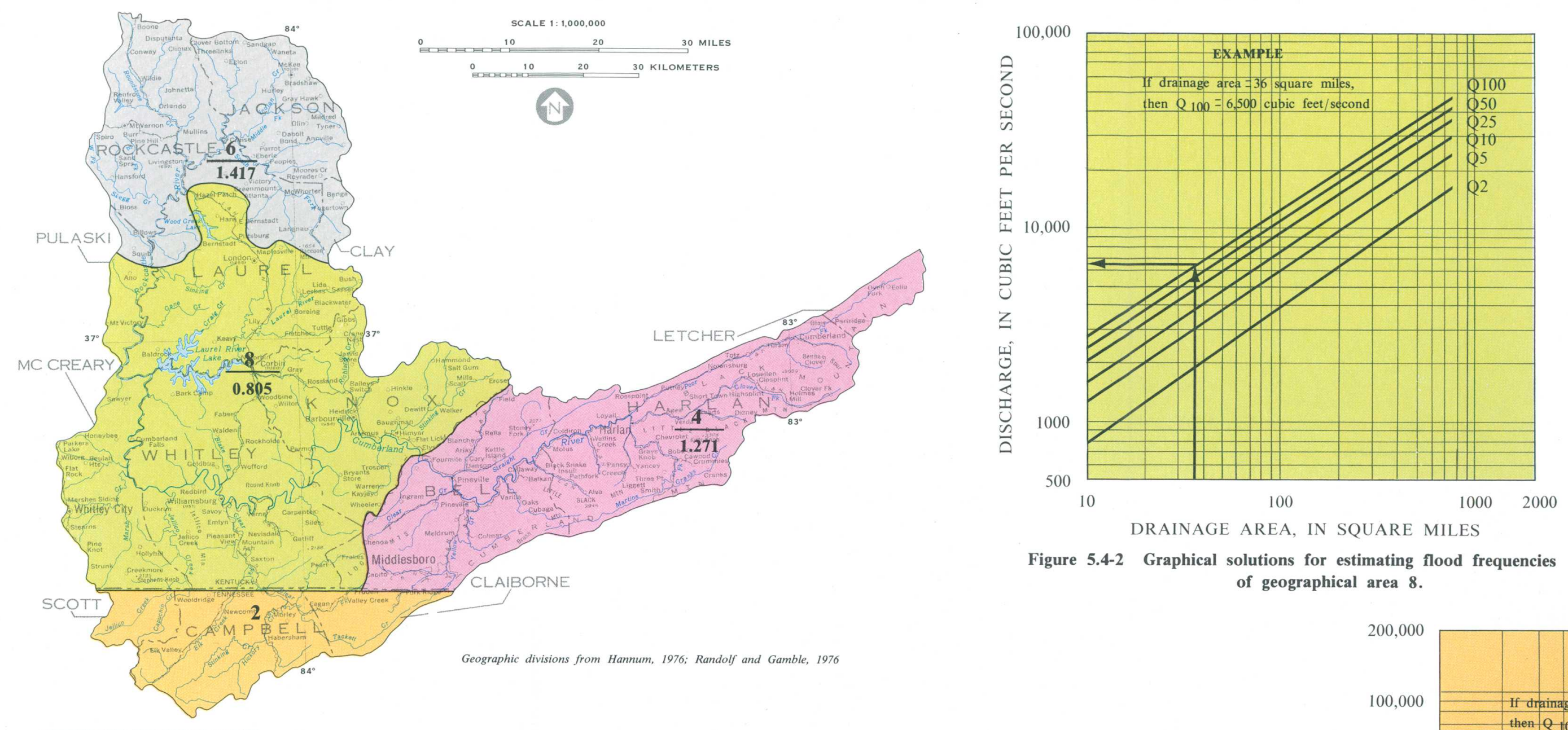

100

Figure 5.4-2 Graphical solutions for estimating flood frequencies of geographical area 8 .

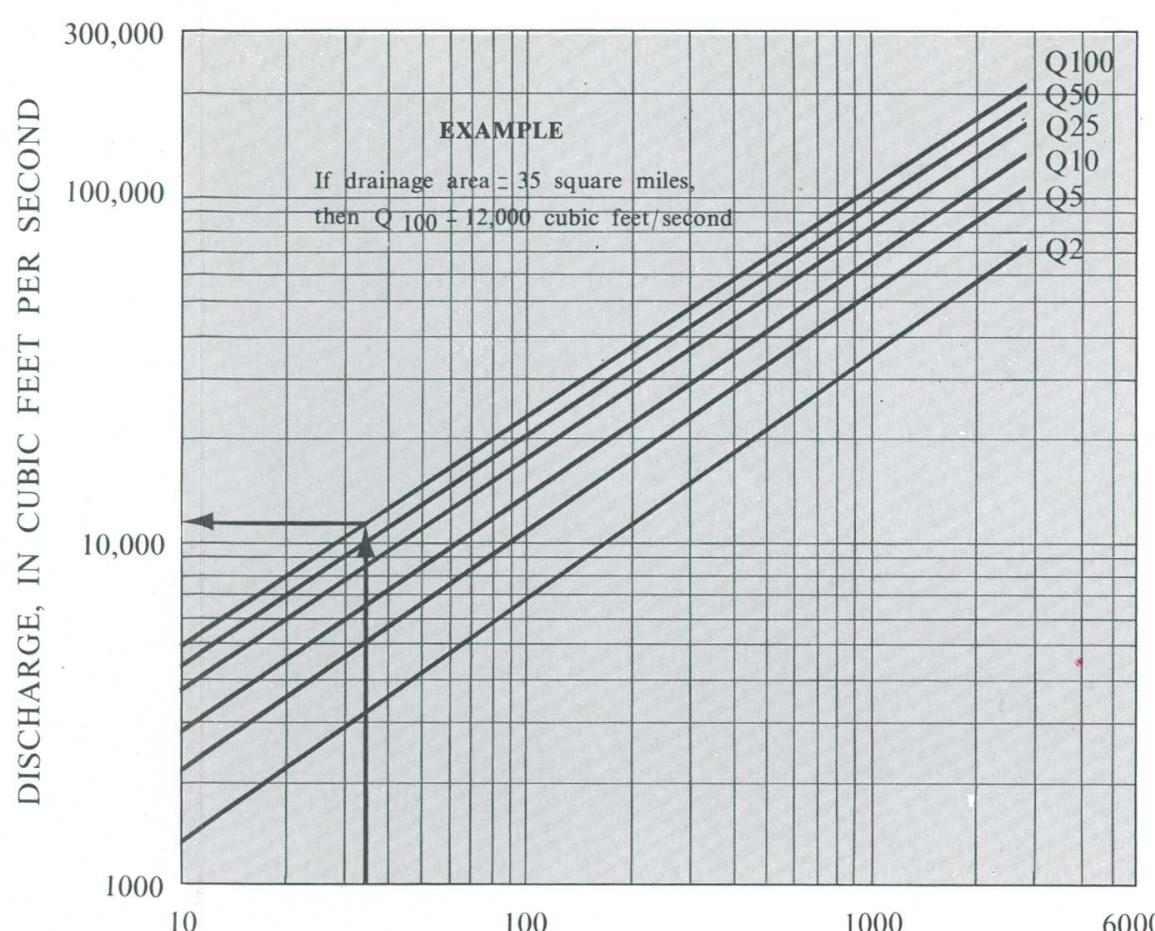

100

1000

Figure 5.4-3 Graphical solutions of the discharge equation for geographical area 6
BASE FROMU.S.S. EEOLOGICAL SURVEY
STATE BASE MAP, 1973

EXPLANATION

\section{$4 \quad$ Geographic area \\ Geographical factor (R) \\ in regression equation}

Figure 5.4-1 Geographic divisions for estimating magnitude and frequency of floods.

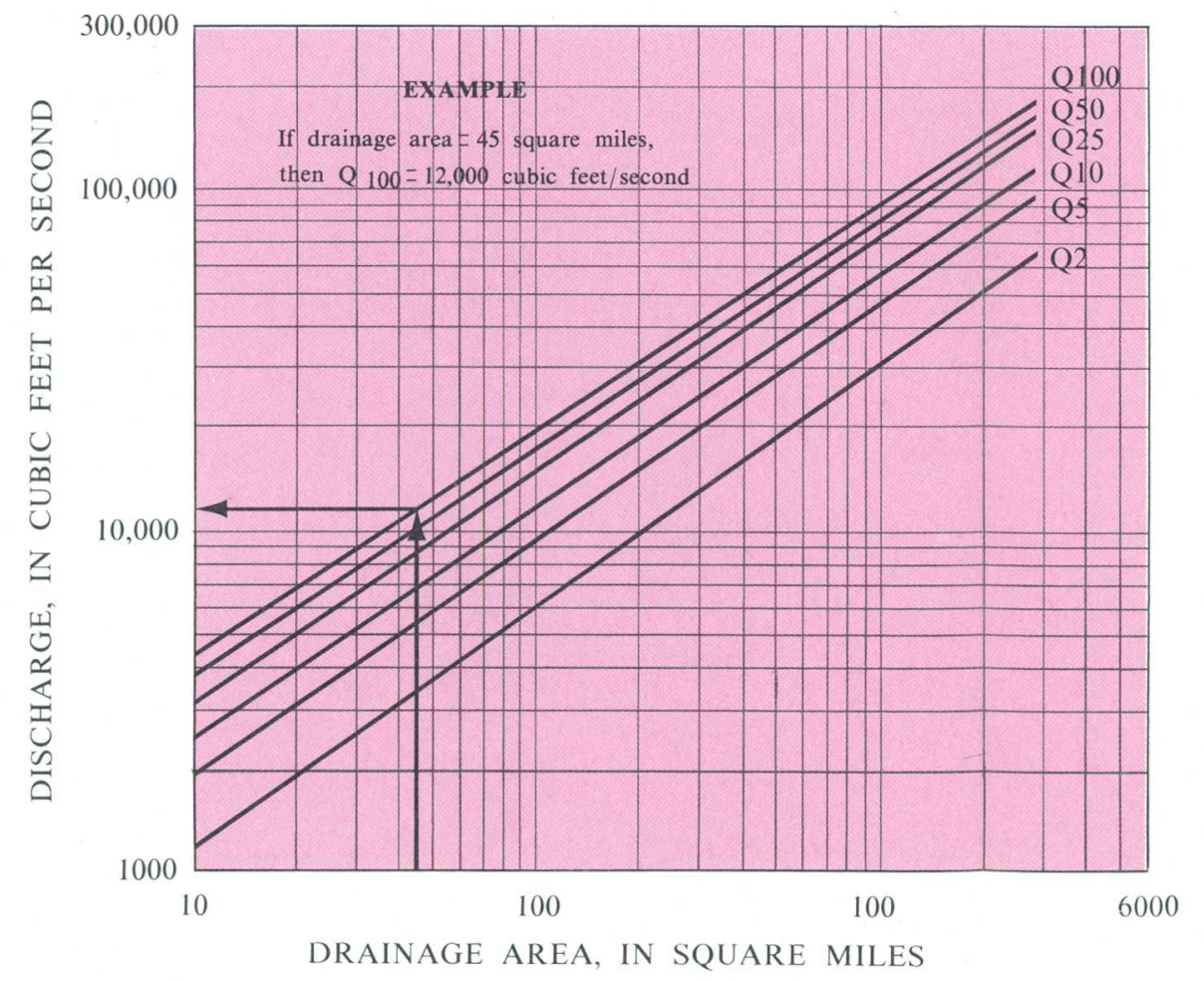

Figure 5.4-4 Graphical solution of the discharge equation for geographical area 4.

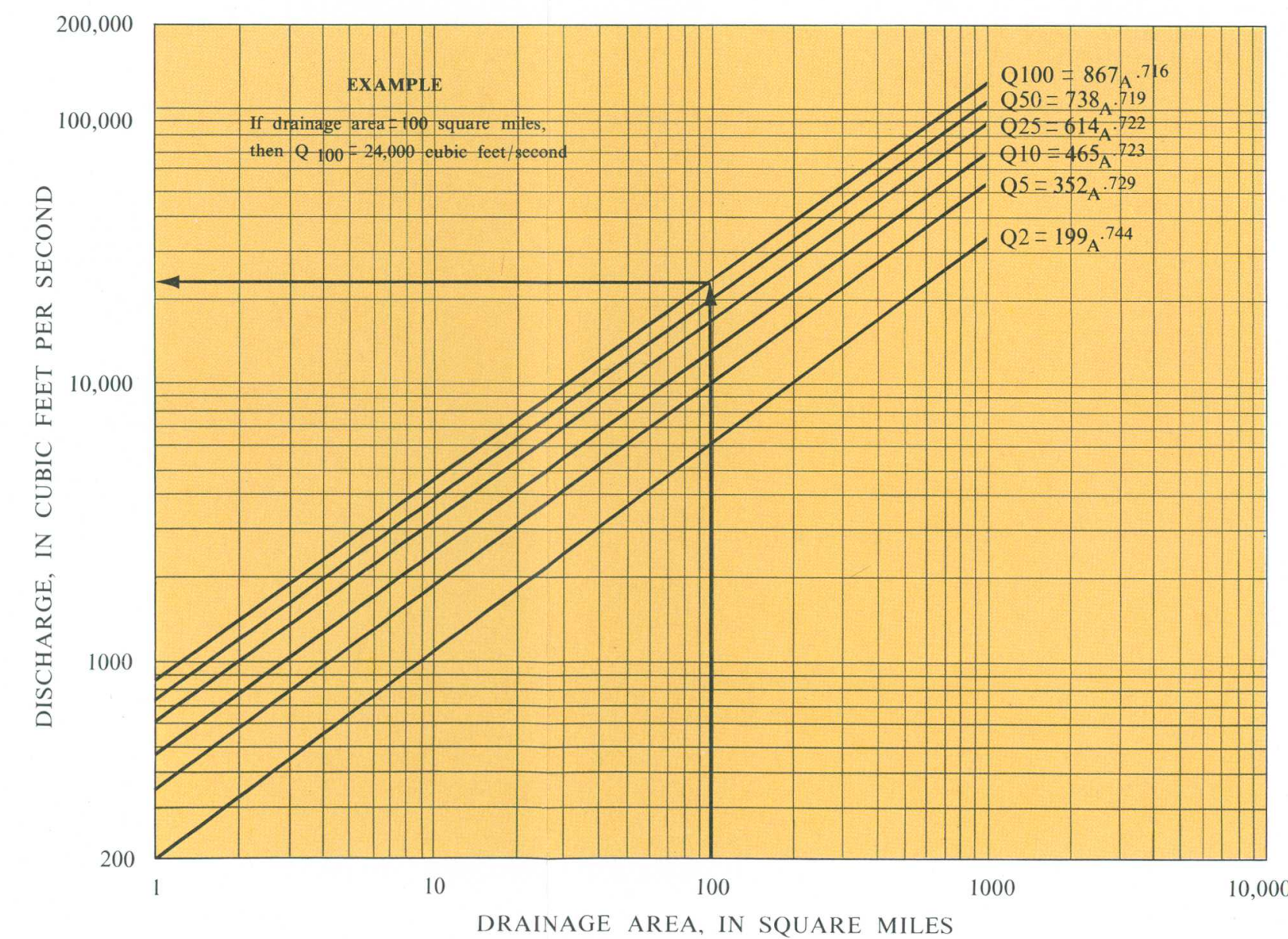

Figure 5.4-5 Graphical solution of the discharge equation for geographical area 2 .

5.0 SURFACE WATER--Continued 


\subsection{SURFACE WATER--Continued 5.5 Flood-Prone Areas}

\section{Maps Delineating Flood-Prone Areas Available}

The limits of the 100-year recurrence-interval flood or the maximum-known flood are shown on 21 maps for parts of Area 15.

The National Flood Insurance Act of 1968, and the Flood Disaster Protection Act of 1973, established programs for investigating the severity and extent of flooding in urban areas and rural communities. In 1968, the U.S. Geological Survey began a program to delineate flood-prone areas and maximum-known floods for selected areas in Kentucky and Tennessee. The objective of the program was to define the 100-year flood in areas identified as subject to flooding. Areas were selected where enough information was available to estimate the altitude of the 100-year flood. A map delineating the maximum-known flood, regardless of the recurrence interval, was prepared for areas where information was not available to define a flood-frequency relation.

Twenty-one flood-prone area maps are available for areas within Area 15 (fig. 5.5-1). These include 12 maps where the 100-year flood has been defined and 9 maps where the maximum-known flood has been delineated. Most of the maximum-flood maps available are along the Cumberland River in the southern part of the area. Areas that may be subject to flooding are delineated on $71 / 2$-minute quadrangle topographic bases at a scale of 1:24,000. 


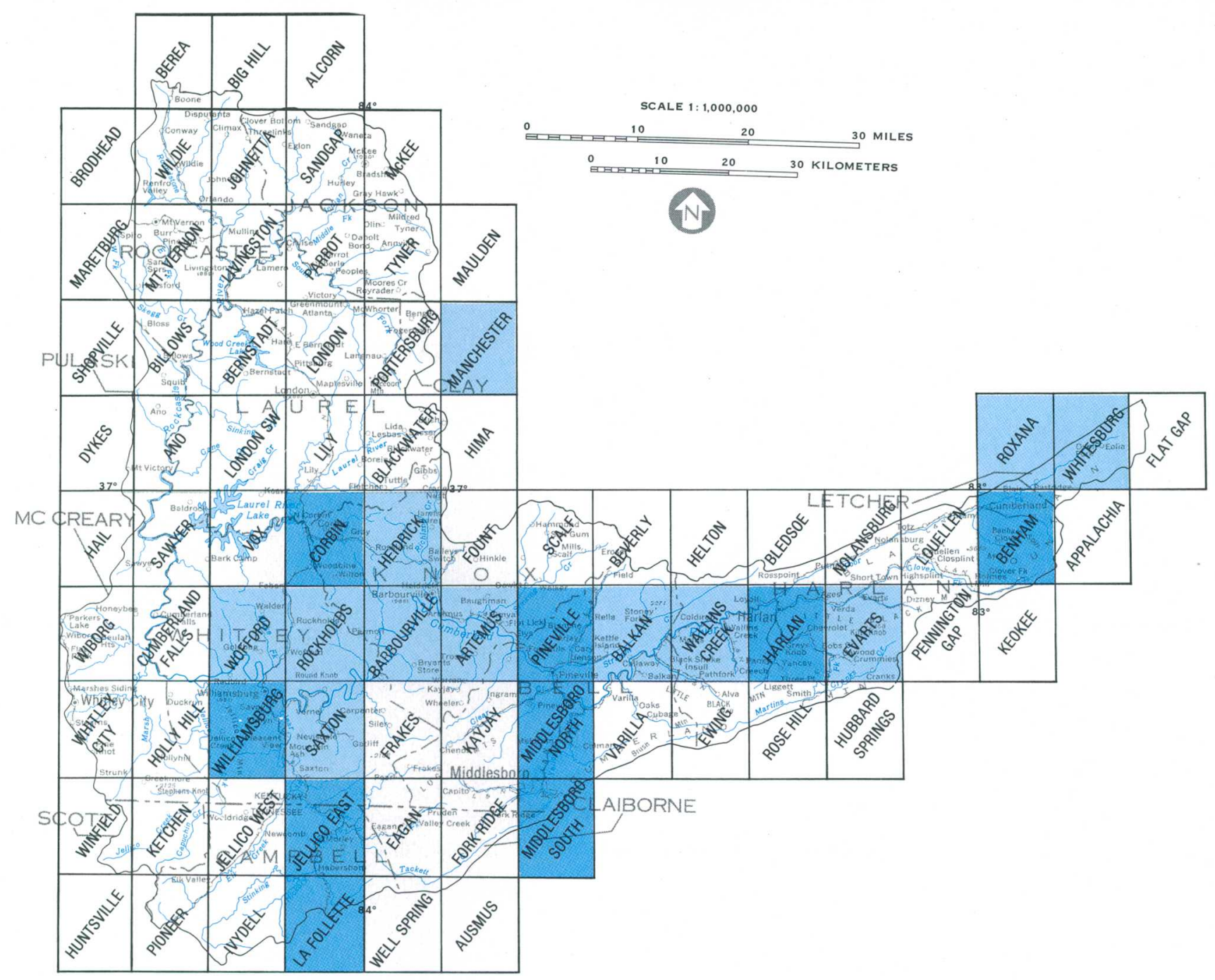

BASE FROM U. S. GEOLOGICAL SURVEY STATE BASE MAP, 1973

\section{EXPLANATION}

Flood-prone area maps

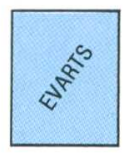

Flood with 100-year frequency

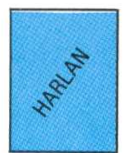

Highest known flood regardless of frequency

Figure 5.5-1 Index of flood-prone area maps. 


\title{
5.0 SURFACE WATER--Continued 5.6 Flow Duration
}

\section{Flow of Streams is Poorly Sustained}

\author{
Flow-duration data are available for 12 stations. Streamflow in Area 15 \\ is highly variable and low flows decrease rapidly during the dry season.
}

The streamflow at a given point is an integration of the partial effects of climate, topography, and geology, providing a distribution of runoff in time and magnitude. The flow duration curve is a cumulative frequency curve that shows the percent of time that a discharge was equalled or exceeded. Mean daily discharges are particularly suitable for flowduration analysis and are available from continuous recording stations. Flow-duration data provide a convenient method of comparing flow characteristics of streams and estimating the percent of time that a given amount of flow was exceeded. Searcy (1959) describes how flow duration data at ungaged sites may be estimated if several streamflow measurements made during low flow are available.

The slope of the flow-duration curve for a stream is a measure of the variability of flow. A steep slope indicates highly variable flow whereas a flat slope indicates more uniform flow which can be caused by surface or ground-water storage contributions.

Flow-duration data are available for 12 stations in Area 15 (fig. 5.6-1 and table 5.6-1). Data are available from 10 sites in mined basins and 2 sites in the Rockcastle River basin, which is only partially mined.

The flow-duration curves from sites in Area 15 are typical of basins with steep slopes, high surface runoff rates, and minor contributions to streamflow from ground water (fig. 5.6-2). The curves are for different periods of record but are presented in unit discharges (flow per square mile) to provide a more direct comparison between the sites. Poor recharge and ground-water storage conditions result in low yields during dry periods. In the basins where coal is mined, although unit base flows are low, discharges appear to be better sustained than in unmined areas. Some of the increase in base flows could be due to increased infiltration of surface runoff in mined areas. Changes in the relief and permeability of the mined area may reduce the slope of the terrain and increase groundwater recharge and subsequently base flow. Similar conditions were observed by Dyer and Curtis (1977) in several small basins in Breathitt County. 


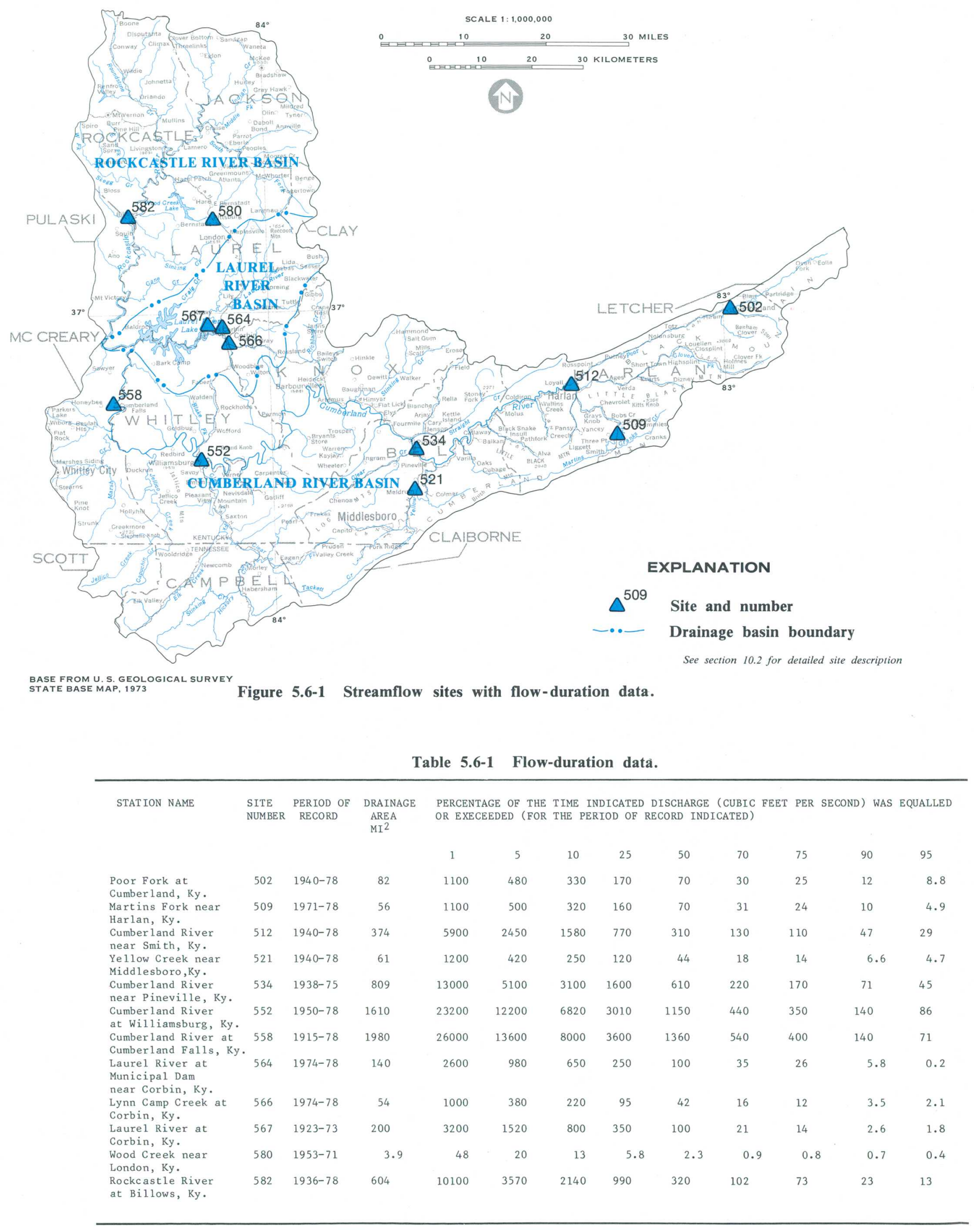

REMARRS: SITR 509 REGULARED BY MARTINS FORK DAM SINCE JAN. 1979.

ITE 521 OCAAS TONALLY REGULATED BY FERN LAKE.
ITRE 534 LOW FLOW REGULAARD BY POWER PLANT 1.9 MLES UPSTREAM

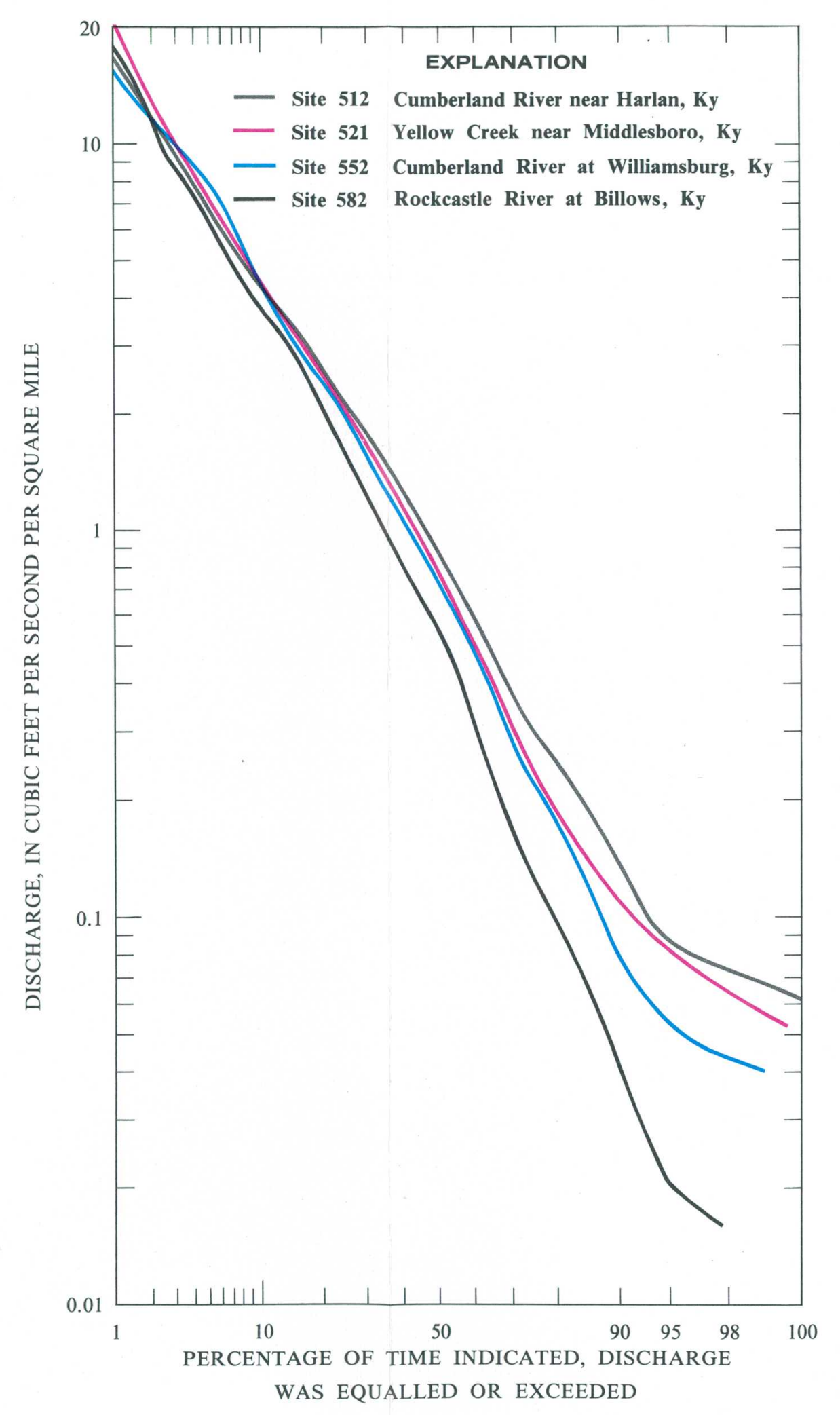

Figure 5.6-2 Flow duration at selected sites.

5.0 SURFACE WATER--Continued 5.6 Flow Duration 


\title{
6.0 QUALITY OF SURFACE WATER \\ 6.1 Introduction
}

\section{Water Quality Data Collected at 38 Active Sites}

\author{
Surface water samples taken in 1979-80, as well as prior samples, provide \\ a general view of seasonal variation of water quality in Area 15.
}

Some of the effects of surface coal-mining activities on the hydrologic environment can be evaluated from water-quality data. The Surface Mining Control and Reclamation Act established a series of permissible ranges and maximum-permissible limits for a number of water-quality characteristics in effluents draining mined areas. These are:

$\bullet \mathrm{pH}$ range from 6.0 to 9.0 units.

-Total manganese concentration of $4,000 \mu \mathrm{g} / \mathrm{L}$ (micrograms per liter)

- Total iron concentration of 7,000 $\mu \mathrm{g} / \mathrm{L}$.

-Total suspended-solids concentration of 70 $\mathrm{mg} / \mathrm{L}$ (milligrams per liter).

Sufficient data to define seasonal water-quality changes are also required by several sections of the Act.

Water-quality data are collected at 38 active sites in Area 15 (fig. 6.1-1 and section 10.2). Determination of $\mathrm{pH}$, specific conductance, alkalinity, temperature, iron and manganese concentrations (total recoverable and dissolved), sulfate, dissolved solids and suspended-sediment concentrations are made in order to define the seasonal water-quality variations.
Additional constituents not specified by the Act were determined from samples collected during low-flow. They include concentrations of the most common dissolved constituents (calcium, magnesium, sodium, potassium, chloride, and fluoride), selected trace constituents (barium, cadmium, chromium, copper, lead, silver, zinc, cyanide, arsenic, mercury, and selenium), and percent of coal in bottom sediments.

In addition to data collected at the 38 active sites, limited water-quality data have been collected in the past at numerous streams in the basin. Many of these sites were re-activated in the present study (section 10.2). Analyses of the historical data, plus the data collected in 1979 and 1980, are presented in the following sections of this report.

Samples were collected in 1979-80 during the spring, summer, and fall seasons in an effort to determine surface water quality during several flow regimes (low, medium, and high flow conditions). The data represent water-quality conditions during extreme low, medium, and some high flows; extreme high-flow conditions were not encountered. Several streams in July and September, 1980, were dry. The data collected provide an instantaneous or synoptic view of water quality during a particular flow condition. 


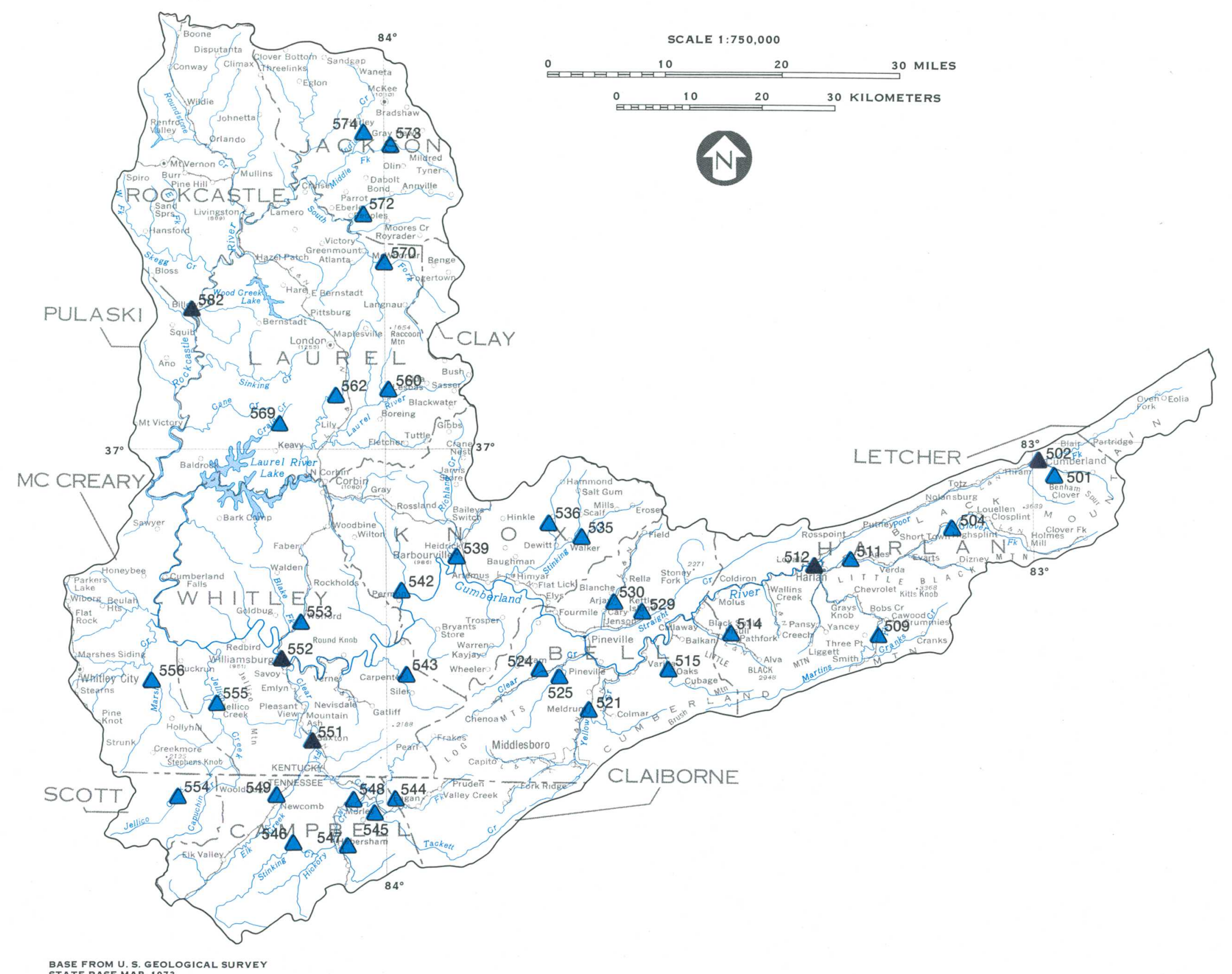

EXPLANATION

Site and number

$\Delta^{512}$ Water samples collected every 6 to 8 weeks; suspended-sediment samples collected 2 to 5 times streamflow

$\Delta^{560} \quad$ Water and suspended-sediment samples collected at 3-month intervals; streamflow measurement made at time of sampling

See section 10.2 for deatied site descripition

BASE FROM U.S.S.EGLOOGICAL SURVE
STATE BASE MAP, 1973

Figure 6.1-1 Water-quality sampling sites. 


\title{
6.0 QUALITY OF SURFACE WATER--Continued \\ 6.2 Specific Conductance and Dissolved Solids
}

\section{Specific Conductance can be Used to Estimate Dissolved Solids}

\author{
Specific conductance values throughout Area 15 range from 41 to 1,750 \\ micromhos per centimeter, while dissolved solids range from 24 to 1,040 \\ milligrams per liter.
}

The specific conductance of water, expressed in units of micromhos per centimeter at $25^{\circ} \mathrm{C}$ ( $\mu$ mhos/ $\mathrm{cm}$ ), is a general indicator of the amount of dissolved solids (Hem, 1970). The simple and inexpensive procedure for the field determination of specific conductance makes it one of the most valuable tools for estimating dissolved-solids concentrations. Dissolved solids at most sites in the area can be estimated by multiplying the specific conductance by a factor of approximately 0.6 ; many of the ions dissolved in water correlate with the specific conductance. For these reasons, specific conductance is routinely determined at all sites where streamflow measurements are made or water samples are collected.

The specific conductance values and the dissolved solids concentrations are affected by the amount of streamflow. The data in table 6.2-1 show that the specific conductance values are higher during low-flow periods (usually in late summer). Dilution of the dissolved constituents occurs during periods of higher flow. During periods of either low or high flows, specific conductance and dissolved-solids values are higher at sites affected by mining than at sites in unmined basins.

Specific conductance values throughout Area 15 range from 41 to $1,750 \mu \mathrm{mhos} / \mathrm{cm}$ (fig. 6.2-1 and table 6.2-1). Minimum instantaneous values range from 41 to $380 \mu \mathrm{mhos} / \mathrm{cm}$; maximum instantaneous values range from 110 to $1,750 \mu \mathrm{mhos} / \mathrm{cm}$.

Dissolved-solids concentrations in the area range from 24 to $1,040 \mathrm{mg} / \mathrm{L}$ (fig.6.2-1 and table 6.2-2).
Minimum values range from 24 to $243 \mathrm{mg} / \mathrm{L}$; $\max$ imum values range from 60 to $1,040 \mathrm{mg} / \mathrm{L}$. The highest dissolved solids and specific conductance values occur in samples collected in the headwaters of the Cumberland River basin, in Harlan and Knox counties, where mining is most intense.

Correlation analyses between specific conductance and dissolved solids are highly significant at both mined and unmined sites in Area 15 (fig. 6.2-2). Dissolved solids and specific conductance values are shown for 1979-80; data used in the regression analysis were 1979-80 and selected historical data. Regression models of Yellow Creek near Middlesboro (site 521, mined and draining Pennsylvanian rocks) and Rockcastle River at Billows (site 582, largely unmined and draining a large area including Mississippian rocks), are highly significant at the $\mathbf{9 5}$ percent confidence level. Similar relations exist at most of the sites in Area 15, with correlation coefficients ( $r$ ) usually higher than 0.9 ; however, at very low specific conductance values (about $50 \mu \mathrm{mhos} / \mathrm{cm}$ and less), this relation becomes poorly defined.

There is no significant difference in the ratios between specific conductance and dissolved solids in water from the two sites shown in figure 6.2-1. However, the range of the values at the Yellow Creek site is about one order of magnitude greater than at the Rockcastle River site. This is probably due to the higher loads of dissolved constituents generated in the basin with mine drainage. Comparison of other sites throughout Area 15 shows similar relations. 

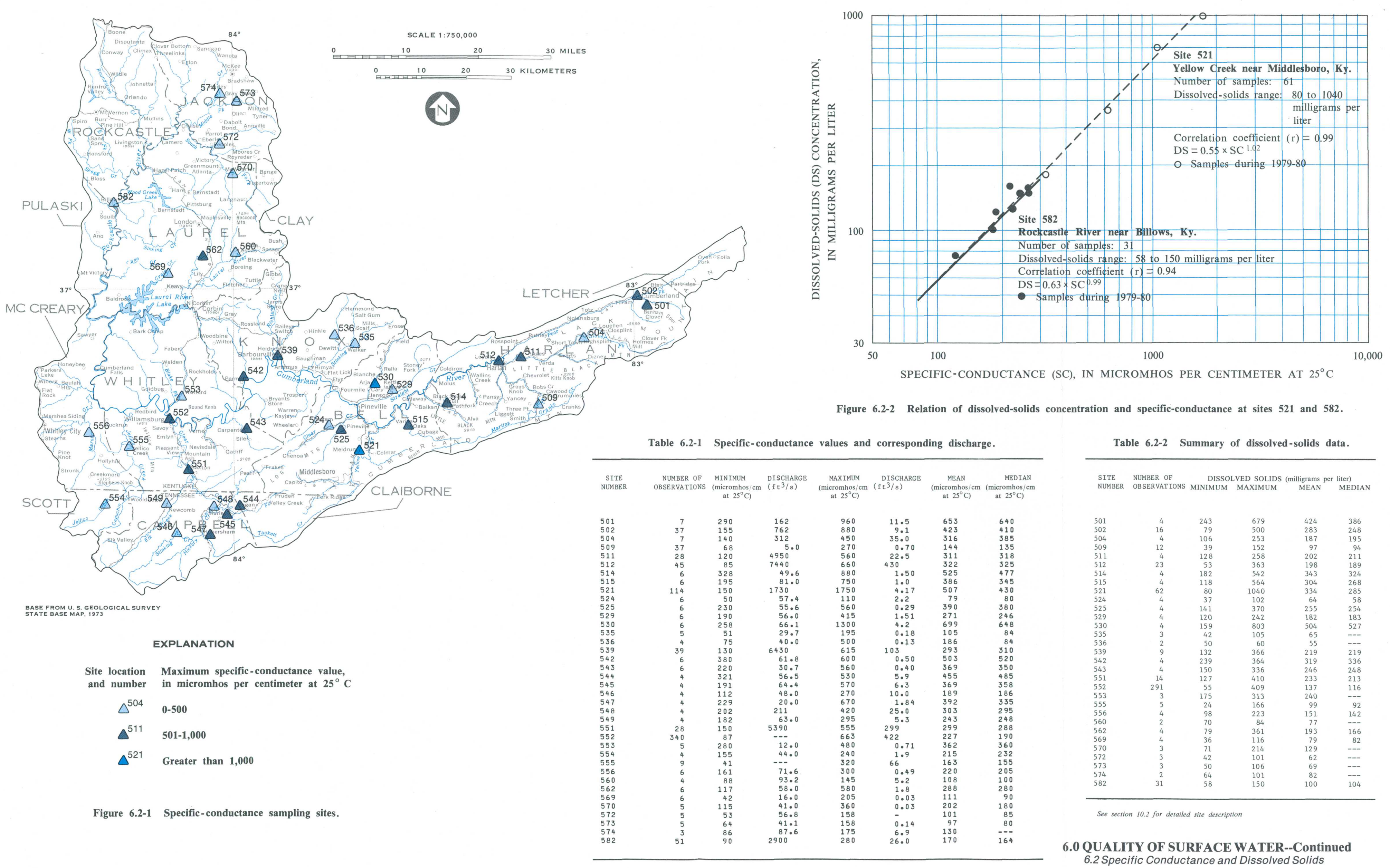

Figure 6.2-2 Relation of dissolved-solids concentration and specific-conductance at sites 521 and 582 .

\begin{tabular}{|c|c|c|c|c|c|c|c|}
\hline $\begin{array}{c}\text { SITE } \\
\text { NUMBER }\end{array}$ & $\begin{array}{c}\text { NUMBER RF } \\
\text { OBSERVAITINS }\end{array}$ & 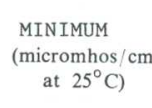 & $\begin{array}{l}\text { DISCAARGE } \\
\left(\mathrm{ft} \mathrm{t}^{3 / s}\right)\end{array}$ & 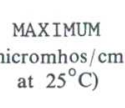 & 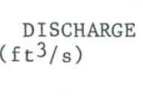 & $\begin{array}{l}\text { MEAN } \\
\text { (mimeromos colm } \\
\text { at } 25^{\circ} \mathrm{C} \text { ) }\end{array}$ & 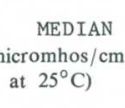 \\
\hline $\begin{array}{l}501 \\
502\end{array}$ & 37 & $\begin{array}{l}290 \\
1.55\end{array}$ & $\begin{array}{l}162 \\
762\end{array}$ & $\begin{array}{l}960 \\
880\end{array}$ & $\begin{array}{c}11.5 \\
99.1\end{array}$ & $\begin{array}{l}653 \\
423\end{array}$ & $\begin{array}{l}640 \\
410\end{array}$ \\
\hline 504 & $\begin{array}{l}37 \\
7\end{array}$ & $\begin{array}{l}155 \\
140\end{array}$ & 312 & $\begin{array}{l}880 \\
450\end{array}$ & $\begin{array}{r}9.1 \\
35.0\end{array}$ & $\begin{array}{l}316 \\
316\end{array}$ & $\begin{array}{l}405 \\
385\end{array}$ \\
\hline $\begin{array}{l}509 \\
511\end{array}$ & $\begin{array}{l}37 \\
28\end{array}$ & $\begin{array}{r}68 \\
120\end{array}$ & 4950.0 & $\begin{array}{l}\begin{array}{l}270 \\
560\end{array} \\
560\end{array}$ & $\begin{array}{r}0.70 \\
22.5\end{array}$ & $\begin{array}{l}144 \\
311 \\
311\end{array}$ & $\begin{array}{l}1155 \\
318\end{array}$ \\
\hline & $\begin{array}{r}45 \\
6\end{array}$ & $\begin{array}{r}85 \\
328\end{array}$ & $\begin{array}{c}7440 \\
49.6\end{array}$ & $\begin{array}{l}660 \\
880\end{array}$ & & $\begin{array}{l}322 \\
525\end{array}$ & \\
\hline $\begin{array}{l}515 \\
521 \\
51\end{array}$ & & 195 & $81: 0^{\circ}$ & $\begin{array}{l}750 \\
750\end{array}$ & 1.0 & 386 & $\begin{array}{l}4115 \\
345\end{array}$ \\
\hline & & $\begin{array}{c}150 \\
50\end{array}$ & $\begin{array}{l}1730 \\
57.4\end{array}$ & $\begin{array}{c}1750 \\
110\end{array}$ & $\begin{array}{l}\begin{array}{l}4.17 \\
2.2\end{array} \\
2.2\end{array}$ & $\begin{array}{r}507 \\
79\end{array}$ & $\begin{array}{l}430 \\
80\end{array}$ \\
\hline & 6 & $\begin{array}{l}230 \\
190\end{array}$ & 55.6 & $\begin{array}{l}560 \\
445\end{array}$ & 0.29 & $\begin{array}{l}390 \\
271\end{array}$ & $\begin{array}{l}380 \\
80\end{array}$ \\
\hline $\begin{array}{l}530 \\
535\end{array}$ & 6 & $\begin{array}{r}258 \\
251 \\
5\end{array}$ & 66.1 & 1300 & 4.2 & 699 & 648 \\
\hline $\begin{array}{l}536 \\
539\end{array}$ & & 75 & $\begin{array}{l}29.1 \\
40.0\end{array}$ & $\begin{array}{l}195 \\
500\end{array}$ & $\begin{array}{l}0.18 \\
0.13\end{array}$ & $\begin{array}{l}105 \\
186\end{array}$ & $\begin{array}{l}884 \\
84\end{array}$ \\
\hline & 39 & $\begin{array}{l}130 \\
380\end{array}$ & & & & & \\
\hline $\begin{array}{l}543 \\
544\end{array}$ & & 220 & 30.7 & 560 & 0.40 & 369 & 350 \\
\hline $\begin{array}{l}544 \\
545\end{array}$ & & $\begin{array}{l}321 \\
191\end{array}$ & $\begin{aligned} 66.5 \\
64.45\end{aligned}$ & $\begin{array}{l}530 \\
5770\end{array}$ & $\begin{array}{l}5.9 \\
6\end{array}$ & $\begin{array}{l}455 \\
369\end{array}$ & $\begin{array}{l}485 \\
355\end{array}$ \\
\hline $\begin{array}{l}546 \\
547\end{array}$ & & 112 & 48.0 & 270 & 10.0 & 189 & 186 \\
\hline 548 & ${ }_{4}^{4}$ & $\begin{array}{l}229 \\
202 \\
202\end{array}$ & 211.0 & $\begin{array}{l}670 \\
420 \\
40\end{array}$ & $\begin{array}{l}1.8 .84 \\
25.0\end{array}$ & $\begin{array}{l}392 \\
303\end{array}$ & $\begin{array}{l}335 \\
295\end{array}$ \\
\hline 551 & 28 & $\begin{array}{l}182 \\
150 \\
150\end{array}$ & $\begin{array}{r}63.0 \\
5390\end{array}$ & $\begin{array}{l}295 \\
555 \\
55\end{array}$ & 299.3 & $\begin{array}{l}243 \\
299 \\
299\end{array}$ & $\begin{array}{l}248 \\
288\end{array}$ \\
\hline $\begin{array}{l}552 \\
553\end{array}$ & $\begin{array}{r}340 \\
5 \\
5\end{array}$ & $\begin{array}{r}87 \\
280\end{array}$ & & $\begin{array}{l}663 \\
6880 \\
480\end{array}$ & 422 & $\begin{array}{l}227 \\
360\end{array}$ & 190 \\
\hline & & 155 & 44.0 & 240 & 1.9 & 215 & 232 \\
\hline 556 & 9 & $\begin{array}{c}41 \\
161\end{array}$ & 71.6 & 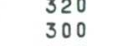 & $\begin{array}{c}66 \\
0.49\end{array}$ & $\begin{array}{l}163 \\
220\end{array}$ & $\begin{array}{l}155 \\
205\end{array}$ \\
\hline 662 & $\begin{array}{l}4 \\
6 \\
\end{array}$ & $\begin{array}{r}88 \\
117\end{array}$ & $\begin{array}{l}93.2 \\
58.0\end{array}$ & $\begin{array}{c}145 \\
580 \\
58\end{array}$ & $\begin{array}{l}5.2 \\
1.8\end{array}$ & $\begin{array}{l}108 \\
288\end{array}$ & $\begin{array}{l}100 \\
280\end{array}$ \\
\hline 70 & $\begin{array}{l}6 \\
5 \\
\end{array}$ & .42 & 16.0 & $\begin{array}{l}205 \\
360\end{array}$ & 0.03 & $\begin{array}{l}111 \\
202\end{array}$ & 90 \\
\hline & & 53 & 56.8 & 158 & & & \\
\hline 582 & 3 & $\begin{array}{l}644 \\
86\end{array}$ & $\begin{array}{l}71.1 \\
87.6\end{array}$ & $\begin{array}{l}170 \\
175\end{array}$ & $\begin{array}{l}0.14 \\
6.9\end{array}$ & 130 & 80 \\
\hline & & & & & & & 164 \\
\hline
\end{tabular}

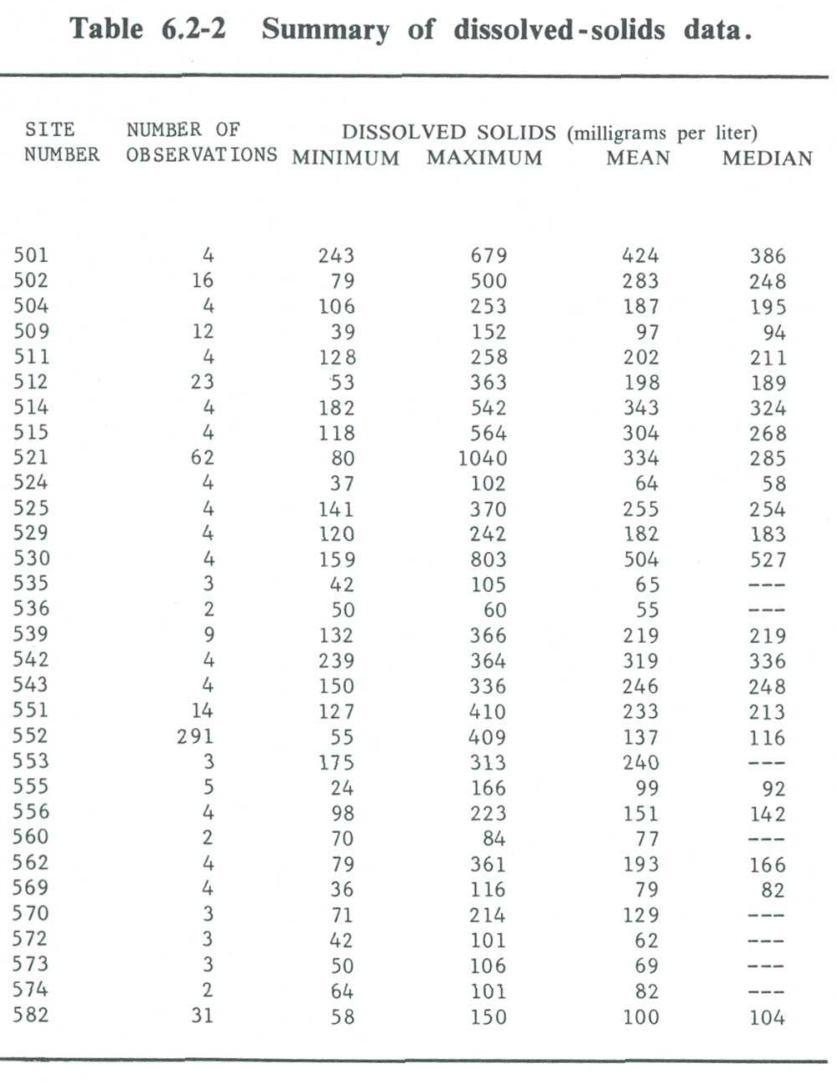

See section 10.2 for deailied site descripition 


\title{
6.0 QUALITY OF SURFACE WATER--Continued $6.3 \mathrm{pH}$
}

\section{pH of Streamflow is Near Neutral at Most Sites}

\author{
The $\mathrm{pH}$ of streams in Area 15 ranges from 5.9 to 8.8 units, but at most sites \\ it is in the 6 to 8 units near-neutral range.
}

The acidity or alkalinity of water is generally expressed in $\mathrm{pH}$ units. A pH value of 7.0 represents neutral water, while values less than 7.0 represent acidic water and greater than 7.0 represent alkaline water. Natural acidity usually is caused by the presence of dissolved carbon dioxide or hydrolysis of salts of weak acids and strong bases. Sources of these substances include rainfall, weathered rocks, and organic matter in soils.

The $\mathrm{pH}$ of waters draining areas affected by surface-coal mining maý be altered by chemical reactions with minerals in mining spoils. In some areas, weathering of pyrite and other sulfur-bearing minerals results in the production of sulfuric acid. The Surface Mining Control and Reclamation Act of 1977 established a permissible range of $\mathrm{pH}$ from 6.0 to 9.0 units for effluents draining mined areas. Acid-mine drainage may have low $\mathrm{pH}$ values in the range from about 2.5 to 5.0 units. Unless the acid is neutralized, the $\mathrm{pH}$ of streams receiving mine drain- age may be lowered below natural levels. In Area 15, rocks contain calcareous minerals, such as calcium carbonate, and acid-mine drainage is quickly neutralized; the $\mathrm{pH}$ of some streams actually increases to alkaline levels ( $\mathrm{pH}$ greater than 7.0) as a result of coal mining activities.

pH data are available from 38 sites throughout Area 15 (fig. 6.3-1). Long-term data are available from only three sites $(512,521$, and 552) while at most of the other sites data collection began in 1979. All of the data available represent instantaneous measurements of $\mathrm{pH}$.

The $\mathrm{pH}$ at stream-sites in Area 15 ranges from 5.9 to 8.8 units (table 6.3-1). Median values range from 7.0 to 8.4 units, but most are in the 7.0 to 7.5 units range. During 1979-80, there were no samples with $\mathrm{pH}$ values less than 6.5 units. 


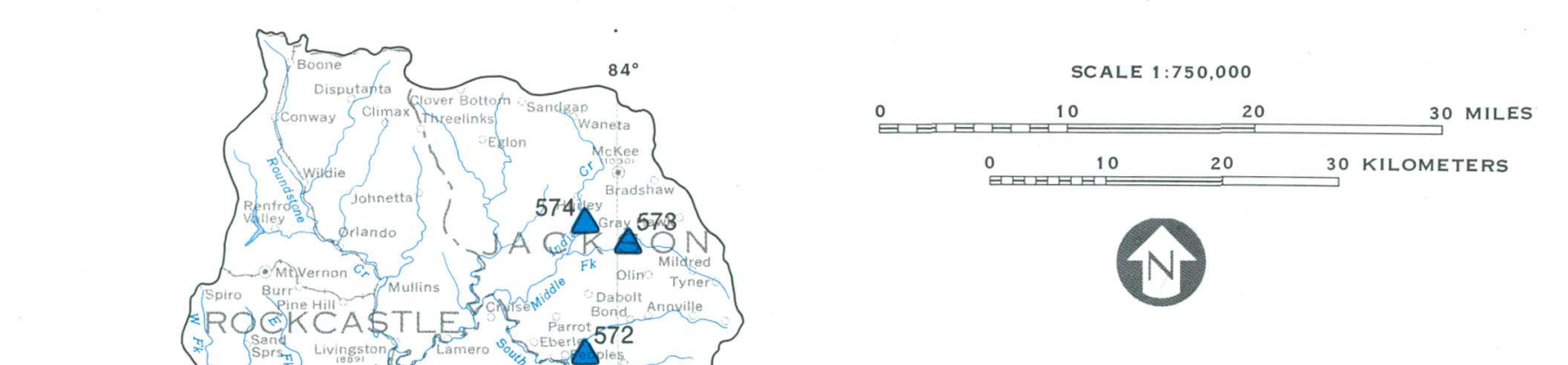

(tioss or

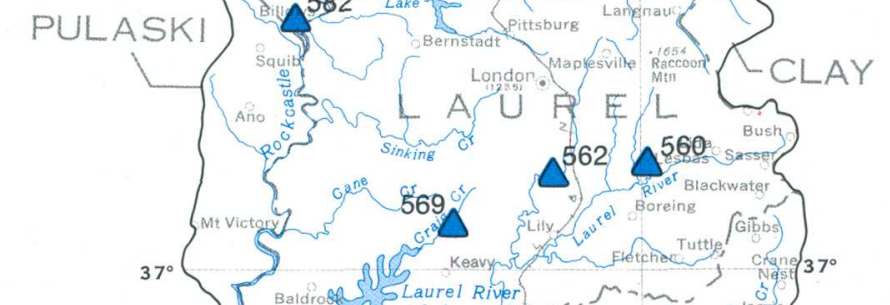

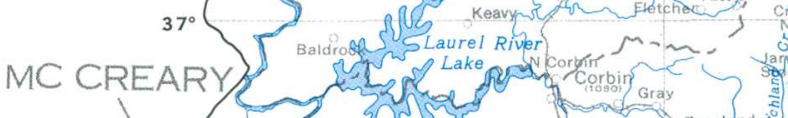

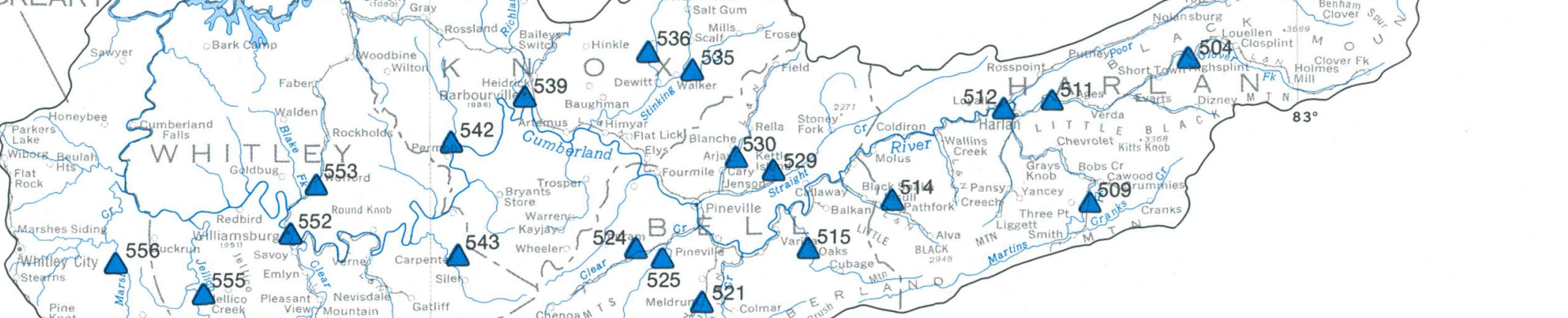

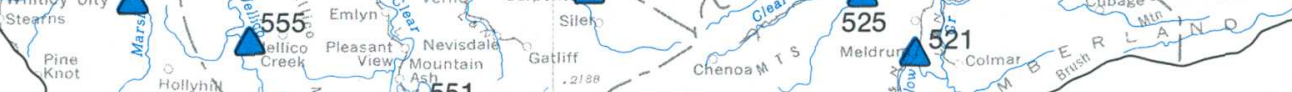

- 3 more $-y^{3}=0$

SCOTT $\Delta^{554}$ U.

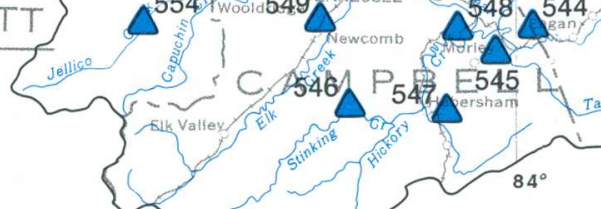

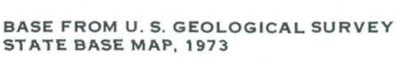

\section{EXPLANATION}

$\triangle^{501}$ Site location and number
Table 6.3-1 $\mathrm{pH}$ data for active sites.

\begin{tabular}{|c|c|c|c|c|}
\hline $\begin{array}{l}\text { SITE } \\
\text { NUMBER }\end{array}$ & $\begin{array}{l}\text { NUMBER OF } \\
\text { OBSERVATIONS }\end{array}$ & MINIMUM & $\begin{array}{l}\text { MAXIMUM } \\
\text { (UNITS) }\end{array}$ & MEDIAN \\
\hline 501 & 7 & 7.8 & 8.5 & 8.4 \\
\hline 502 & 18 & 7.6 & 8.8 & 8.0 \\
\hline 504 & 7 & 7.2 & 8.1 & 7.6 \\
\hline 509 & 10 & 6.5 & 7.5 & 7.1 \\
\hline 511 & 6 & 7.4 & 8.6 & 7.8 \\
\hline 512 & 26 & 6.7 & 8.2 & 7.8 \\
\hline 514 & 6 & 7.6 & 8.4 & 8.2 \\
\hline 515 & 6. & 7.4 & 8.0 & 7.8 \\
\hline 521 & 65 & 6.4 & 8.3 & 7.0 \\
\hline 524 & 6 & 7.1 & 7.4 & 7.2 \\
\hline 525 & 6 & 7.8 & 8.4 & 8.0 \\
\hline 529 & 6 & 7.2 & 7.8 & 7.4 \\
\hline 530 & 6 & 7.2 & $7: 8$ & 7.6 \\
\hline 535 & 5 & 7.0 & 7.4 & 7.2 \\
\hline 536 & 4 & 6.8 & 7.2 & 7.0 \\
\hline 539 & 12 & 7.4 & 8.0 & 7.7 \\
\hline 542 & 6 & 7.4 & 7.7 & 7.4 \\
\hline 543 & 6 & 7.3 & 7.9 & 7.6 \\
\hline 544 & 4 & 7.5 & 8.1 & 7.6 \\
\hline 545 & 4 & 7.7 & 8.1 & 7.9 \\
\hline 546 & 4 & 6.9 & 8.2 & 7.4 \\
\hline 547 & 4 & 7.6 & 8.5 & 8.0 \\
\hline 548 & 4 & 6.9 & 7.9 & 7.5 \\
\hline 549 & 4 & 7.3 & 7.5 & 7.4 \\
\hline 551 & 17 & 7.0 & 8.0 & 7.4 \\
\hline 552 & 219 & 5.9 & 8.1 & 7.1 \\
\hline 553 & 5 & 7.4 & 7.6 & 7.6 \\
\hline 554 & 4 & 6.9 & 7.6 & 7.0 \\
\hline 555 & 6 & 7.0 & 7.3 & 7.2 \\
\hline 556 & 4 & 6.9 & 7.6 & 7.0 \\
\hline 560 & 4 & 6.8 & 7.2 & 7.0 \\
\hline 562 & 6 & 6.6 & 7.4 & 7.0 \\
\hline 569 & 6 . & 6.8 & 7.6 & 7.2 \\
\hline 570 & 5 & 6.8 & 7.6 & 7.1 \\
\hline 572 & 5 & 7.2 & 7.6 & 7.4 \\
\hline 573 & 5 & 7.2 & 7.5 & 7.2 \\
\hline 574 & 3 & 7.2 & 7.8 & -- \\
\hline 582 & 8 & 7.6 & 8.2 & 7.8 \\
\hline
\end{tabular}

See section 10.2 for decailed site description

Figure 6.3-1 $\mathrm{pH}$ sampling sites. 


\title{
6.0 QUALITY OF SURFACE WATER--Continued 6.4 Sulfate
}

\section{Sulfate Concentrations are Highest at Sites in the Cumberland River Basin}

\author{
At most sites in the headwaters of the Cumberland River Basin, median \\ sulfate concentrations exceed $50 \mathrm{mg} / \mathrm{L}$ and are as high as $180 \mathrm{mg} / \mathrm{L}$.
}

Surface mining exposes soils and rocks to weathering and oxidation. Sulfuric acid is produced when minerals containing sulfur are oxidized. Dissolved sulfate and large amounts of dissolved solids are in effluents from coal-mining operations. Sulfate concentrations are commonly used as an indicator of mine drainage. Concentrations in streams draining relatively unmined basins generally are low (1 to 20 $\mathrm{mg} / \mathrm{L}$ ), while concentrations from mined areas are highly variable and may be very high (20 to 200 $\mathrm{mg} / \mathrm{L}$ ) (Dyer and Curtis, 1977).

The variability of sulfate concentrations in streams draining mined areas is primarily due to the presence of reactive minerals in spoil material, the length of time of exposure of these materials to weathering, the length of time water is in contact with the spoils, and the quantity of water leaving the mined areas. Sulfate concentrations are highest during low flow, when contact time with spoil has been fairly long, and water draining from spoil material may constitute a significant part of the flow. Sulfate Concentrations are lower during high flow when contact time is short and dilution occurs.

Sulfate-concentration data are available from 38 active sites in Area 15 (fig. 6.4-1). The data show that sulfate concentrations range from 4.5 to 998 $\mathrm{mg} / \mathrm{L}$ (table 6.4-1). At 24 of the sites, median sulfate concentrations exceed $50 \mathrm{mg} / \mathrm{L}$, indicating minedrainage effects. The highest sulfate concentrations are at sites in the Cumberland River basin, where most of the mining occurs in Area 15. In the headwaters of the basin, in Bell and Harlan Counties, sulfate concentrations range from 6.4 to $998 \mathrm{mg} / \mathrm{L}$. In comparison, the lowest concentrations ranged from 7.6 to $74 \mathrm{mg} / \mathrm{L}$ at sites in the Rockcastle River basin, in Jackson and Laurel Counties. Most of the Rockcastle River basin is in the Daniel Boone National Forest, where no significant surface mining occurs. In addition, the Rockcastle River drains an area of Mississippian limestone and shale that contain relatively small amounts of sulfurous minerals.

Significant correlation exists between sulfate concentration and specific conductance at sites affected by mine drainage (fig. 6.4-2). At the site in the Rockcastle River basin (site 582), where no significant mining occurs, the correlation is poor.

Comparison of sulfate concentrations and streamflow at the three sites (table 6.4-2) shows an inverse correlation (sulfate concentration decreases as discharge increases) at sites draining mined areas and poor correlation exist at unmined sites. At the Rockcastle River site (582), a significant reduction in the sulfate concentration did not occur until the flow increased to $1,710 \mathrm{ft}^{3} / \mathrm{s}$ (table 6.4-2). The same trend prevails at other sites in the basin, with even lower sulfate concentrations. 


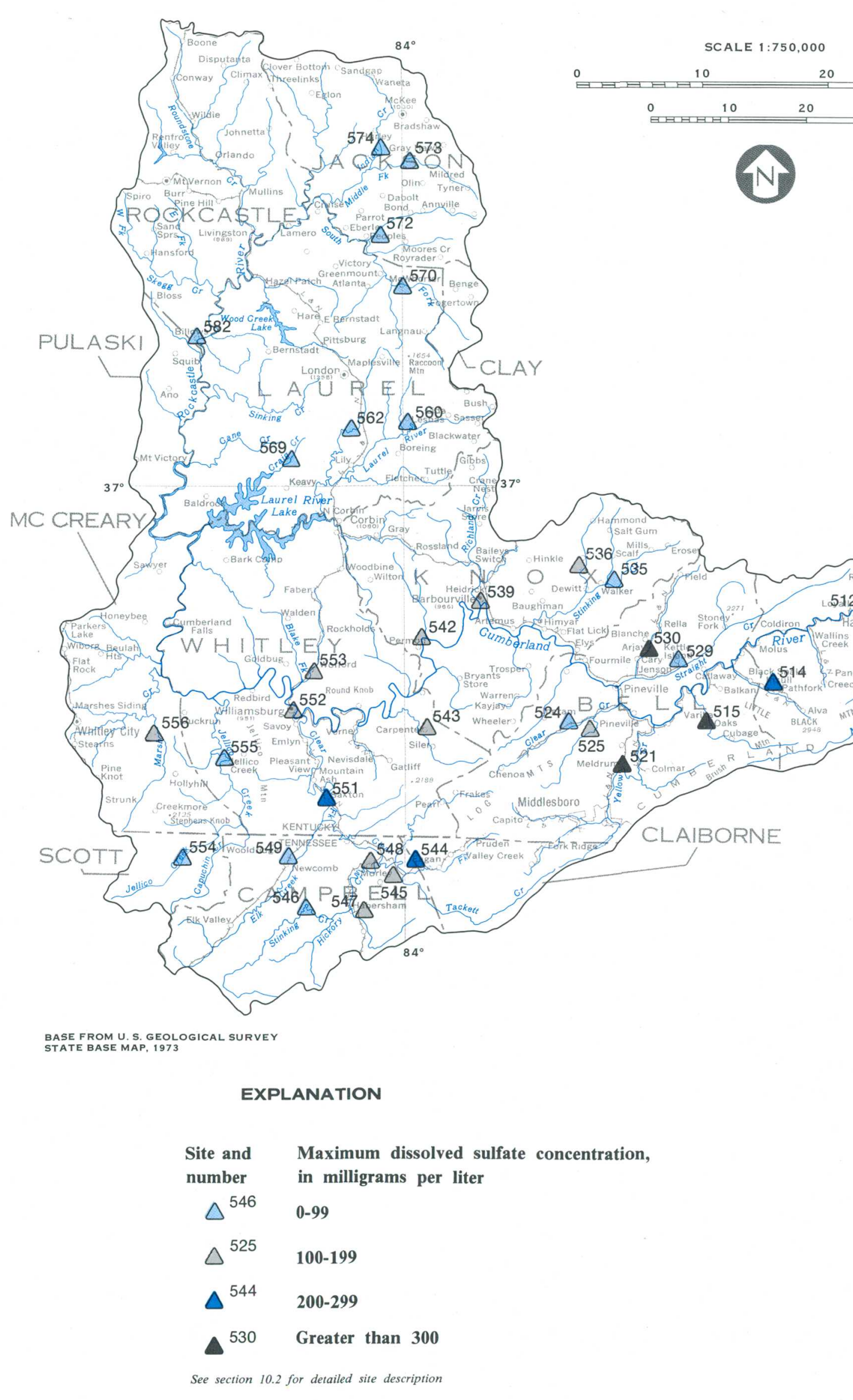

Figure 6.4-1 Sulfate sampling sites.

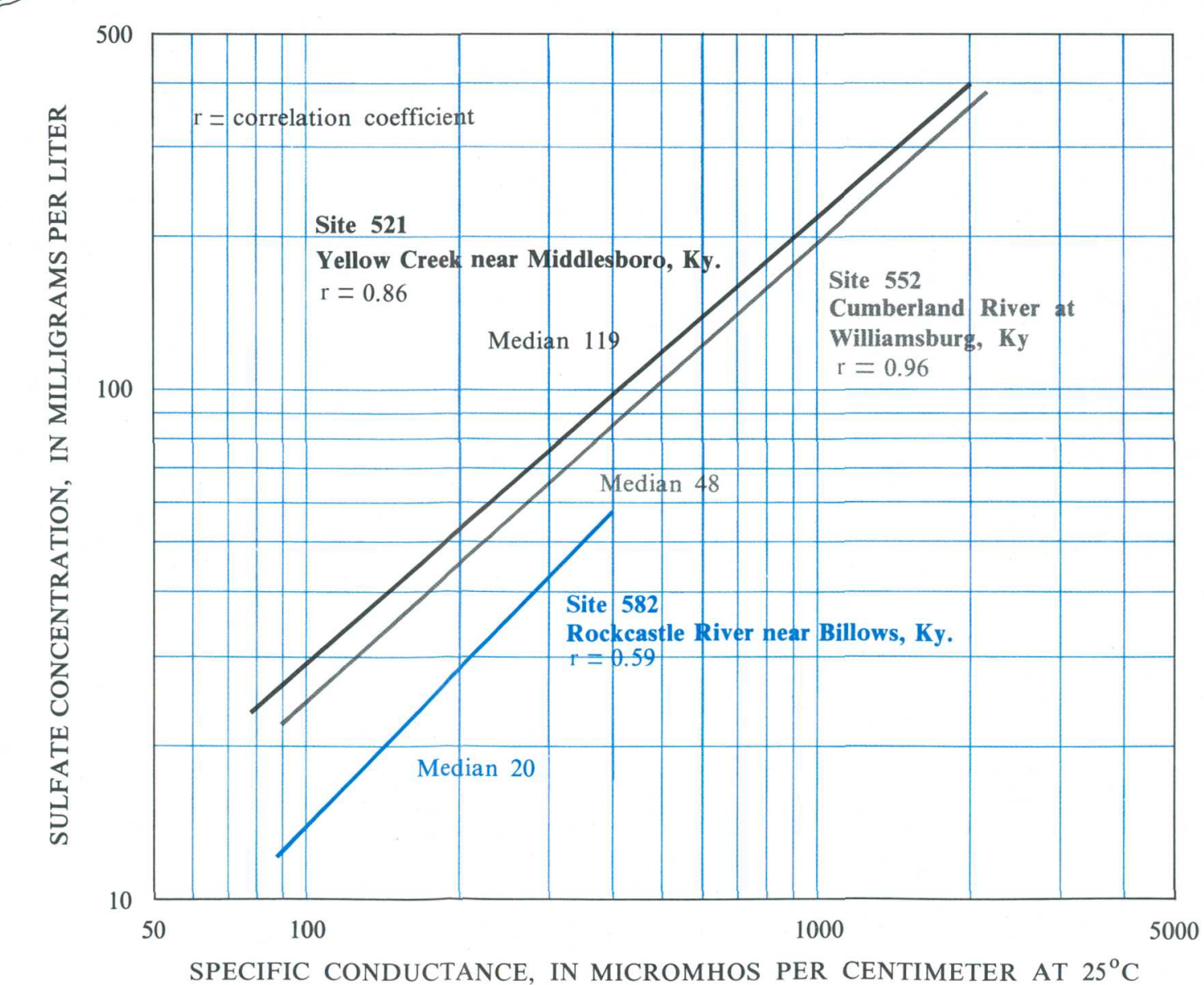

Figure 6.4-2 Relation of sulfate concentrations to specific conductance at sites 521 , 552 , and 582 .
Table 6.4-1 Sulfate data for active sites.

\begin{tabular}{|c|c|c|c|c|c|}
\hline $\begin{array}{c}\text { SITE } \\
\text { NUMBER }\end{array}$ & $\begin{array}{l}\text { NUMBER OF } \\
\text { OBSERVATIONS }\end{array}$ & MINIMUM & $\begin{array}{l}\text { MAXIMUM } \\
\text { (Milligrams }\end{array}$ & MEAN & MEDIÁN \\
\hline & & & & & \\
\hline $\begin{array}{l}501 \\
502\end{array}$ & $\begin{array}{r}6 \\
18\end{array}$ & $\begin{array}{l}63 \\
30 \\
30\end{array}$ & 200 & $\begin{array}{r}115 \\
73\end{array}$ & $\begin{array}{c}110 \\
70\end{array}$ \\
\hline $\begin{array}{l}502 \\
504\end{array}$ & $\begin{array}{r}18 \\
6\end{array}$ & $\begin{array}{l}30 \\
32 \\
32\end{array}$ & $\begin{array}{r}120 \\
78\end{array}$ & $\begin{array}{l}73 \\
56\end{array}$ & $\begin{array}{l}10 \\
58\end{array}$ \\
\hline $\begin{array}{l}509 \\
511\end{array}$ & 14 & 15 & 75 & $\begin{array}{l}41 \\
65\end{array}$ & 38 \\
\hline $\begin{array}{l}511 \\
512\end{array}$ & $\begin{array}{r}6 \\
24\end{array}$ & $\begin{array}{l}40 \\
18\end{array}$ & $\begin{array}{l}78 \\
96\end{array}$ & $\begin{array}{l}65 \\
60 \\
60\end{array}$ & $\begin{array}{l}74 \\
59\end{array}$ \\
\hline 514 & 6 & 85 & 240 & 149 & 140 \\
\hline $\begin{array}{l}515 \\
521\end{array}$ & $\begin{array}{r}6 \\
65\end{array}$ & $\begin{array}{l}60 \\
39\end{array}$ & $\begin{array}{l}300 \\
998\end{array}$ & $\begin{array}{l}137 \\
131\end{array}$ & 116 \\
\hline $\begin{array}{l}521 \\
524\end{array}$ & $\begin{array}{r}65 \\
6\end{array}$ & $\begin{array}{c}39 \\
6.4\end{array}$ & $\begin{array}{r}998 \\
13\end{array}$ & $\begin{array}{r}131 \\
8 .\end{array}$ & $\begin{array}{c}119 \\
8.3\end{array}$ \\
\hline $\begin{array}{l}224 \\
525\end{array}$ & 6 & 56 & 180 & $110^{\circ}$ & 101 \\
\hline $\begin{array}{l}529 \\
530\end{array}$ & $\begin{array}{l}6 \\
6\end{array}$ & $\begin{array}{l}53 \\
81\end{array}$ & $\begin{array}{r}93 \\
410\end{array}$ & $\begin{array}{r}74 \\
218\end{array}$ & $\begin{array}{r}74 \\
180\end{array}$ \\
\hline 535 & $\begin{array}{l}0 \\
5\end{array}$ & 9.4 & 12 & 10 & $\begin{array}{l}100.7 \\
9.7\end{array}$ \\
\hline $\begin{array}{l}536 \\
539\end{array}$ & $\begin{array}{c}4 \\
12\end{array}$ & 17 & $\begin{array}{l}130 \\
110\end{array}$ & 47 & $\begin{array}{l}20 \\
80 \\
80\end{array}$ \\
\hline $\begin{array}{l}539 \\
542\end{array}$ & $\begin{array}{c}12 \\
6 \\
\end{array}$ & $\begin{array}{r}41 \\
130\end{array}$ & $\begin{array}{l}\begin{array}{l}110 \\
180\end{array}\end{array}$ & $\begin{array}{l}74 \\
160\end{array}$ & $\begin{array}{c}80 \\
165\end{array}$ \\
\hline 543 & 6 & 69 & 140 & 102 & 98 \\
\hline $\begin{array}{l}544 \\
545\end{array}$ & 4 & $\begin{array}{l}110 \\
110\end{array}$ & $\begin{array}{l}220 \\
160\end{array}$ & $\begin{array}{l}168 \\
102\end{array}$ & $\begin{array}{c}170 \\
98\end{array}$ \\
\hline $\begin{array}{l}543 \\
546\end{array}$ & $\begin{array}{l}4 \\
4\end{array}$ & $\begin{array}{l}53 \\
34\end{array}$ & $\begin{array}{c}160 \\
87\end{array}$ & $\begin{array}{r}02 \\
60\end{array}$ & $\begin{array}{l}98 \\
60\end{array}$ \\
\hline 547 & $\begin{array}{l}4 \\
4\end{array}$ & $\begin{array}{l}3.54 \\
64\end{array}$ & 190 & $\begin{array}{l}00 \\
110\end{array}$ & 93 \\
\hline $\begin{array}{l}548 \\
549\end{array}$ & $\begin{array}{l}4 \\
4\end{array}$ & 68 & $\begin{array}{r}140 \\
69\end{array}$ & $\begin{array}{r}105 \\
57\end{array}$ & $\begin{array}{l}106 \\
59\end{array}$ \\
\hline $\begin{array}{l}349 \\
551\end{array}$ & $\begin{array}{l}4 \\
16\end{array}$ & ${ }_{52}^{42}$ & $\begin{array}{r}69 \\
200\end{array}$ & $\begin{array}{r}57 \\
108\end{array}$ & $\begin{array}{l}59 \\
92 \\
92\end{array}$ \\
\hline $\begin{array}{l}552 \\
553\end{array}$ & 214 & 19 & 159 & 54 & 48 \\
\hline & 5 & $\begin{array}{l}88 \\
53\end{array}$ & $\begin{array}{r}160 \\
94\end{array}$ & $\begin{array}{l}114 \\
82\end{array}$ & 110 \\
\hline $\begin{array}{l}554 \\
555\end{array}$ & $\begin{array}{l}4 \\
9 \\
\end{array}$ & $\begin{array}{c}53.6 \\
7.6\end{array}$ & $\begin{array}{l}94 \\
83\end{array}$ & $\begin{array}{l}82 \\
45\end{array}$ & $\begin{array}{l}92 \\
48\end{array}$ \\
\hline 556 & 6 & 50 & 110 & 78 & 70 \\
\hline $\begin{array}{l}560 \\
562\end{array}$ & $\begin{array}{l}4 \\
6\end{array}$ & $\begin{array}{l}15 \\
18 \\
\end{array}$ & 29 & $\begin{array}{l}21 \\
21 \\
28\end{array}$ & 20 \\
\hline $\begin{array}{l}562 \\
569\end{array}$ & 6 & 4.5 & $\begin{array}{r}42.0 \\
7.0\end{array}$ & 5. & 5.2 \\
\hline $\begin{array}{r}570 \\
572\end{array}$ & 5 & 23 & 74 & 45 & 38 \\
\hline 573 & 5 & $\begin{array}{l}7.6 \\
7.8\end{array}$ & $\begin{array}{l}8.8 \\
11\end{array}$ & $\begin{array}{l}8 . \\
9 .\end{array}$ & $\begin{array}{l}8.4 \\
9.4\end{array}$ \\
\hline & 3 & 14 & $\begin{array}{l}40 \\
51\end{array}$ & 33 & 20 \\
\hline
\end{tabular}

Table 6.4-2 Relation of sulfate concentration to streamflow at sites 521,552 , and 582.

\begin{tabular}{ccc}
\hline SITE NUMBER & $\begin{array}{c}\text { STREAMF LOW } \\
\mathrm{FT}^{3} / \mathrm{S}\end{array}$ & $\begin{array}{c}\text { SULFATE } \\
\text { MG/L }\end{array}$ \\
552 & 62 & 120 \\
& 178 & 84 \\
& 314 & 94 \\
& 877 & 69 \\
& 2620 & 50 \\
& 4480 & 67 \\
521 & 6170 & 41 \\
& 4.2 & 250 \\
& 8.9 & 190 \\
& 34 & 130 \\
582 & 92 & 699 \\
& 261 & 72 \\
& 8.0 & 43 \\
& 32 & 44 \\
& 181 & 29 \\
& 272 & 31 \\
& 464 & 39 \\
& 900 & 34 \\
& 1710 & 19 \\
\hline
\end{tabular}

6.0 QUALITY OF SURFACE WATER--Continued 


\title{
6.0 QUALITY OF SURFACE WATER--Continued 6.5 Iron
}

\section{Iron Concentrations Vary with Location and Discharge}

\author{
The total recoverable iron concentration in streams in Area 15 increases \\ with flow and is generally higher at sites draining mined areas. The \\ dissolved fraction is relatively minor; most of the iron is suspended.
}

Iron is common in rocks and in soils rich in organic material. Surface mining exposes rocks and soils to weathering, accelerating the oxidation and dissolution of iron compounds. In addition to dissolved iron, large amounts of iron compounds are transported in suspension.

Dissolved and total recoverable iron concentrations (suspended plus dissolved) are important water-quality parameters that affect the suitability of water for domestic and industrial uses. Dissolvediron concentrations in excess of $300 \mu \mathrm{g} / \mathrm{L}$ cause staining, impart an undesirable taste to water, and require treatment for most uses (U.S. Environmental Protection Agency, 1976). In streams, dissolved iron may precipitate, producing "yellow boy" (ferrous hydroxide, ochre-yellow precipitate), which flocculates and settles on river beds adversely affecting bottom aquatic life. The Act established a permissible limit of 7,000 $\mu \mathrm{g} / \mathrm{L}$ of iron for effluents from mined areas.

Determinations of iron concentrations are available from 38 active sites in Area 15 (fig. 6.5-1). Total recoverable iron concentrations in streams in Area 15 range from 10 to $46,000 \mu \mathrm{g} / \mathrm{L}$ (table 6.5-1). However, in most streams, mean concentrations exceed $1,000 \mu \mathrm{g} / \mathrm{L}$, but are less than $2,000 \mu \mathrm{g} / \mathrm{L}$. Maximum recommended concentrations for aquatic life of $1,000 \mu \mathrm{g} / \mathrm{L}$ and for drinking water of $300 \mu \mathrm{g} / \mathrm{L}$ (U.S. Environmental Protection Agency, 1976) are fre- quently exceeded at many sites in both mined and unmined basins.

The highest total recoverable iron concentrations occur at sites in the headwaters of the Cumberland River basin, where coal mining is most intense. The lowest concentrations usually occur at sites in the largely unmined Rockcastle River basin.

Most of the iron in streamflow in Area 15 is suspended, with only a small fraction in the dissolved phase (table 6.5-2). At most sites in mined and unmined basins, the dissolved iron is usually less than 10 percent of the total recoverable iron. Large increases in flow generally do not result in substantial changes in dissolved-iron concentrations. An increase in suspended iron; however, generally occurs with increasing streamflow at most of the sites.

The transport of iron at selected sites in Area 15 correlates significantly with the suspended-sediment concentration (fig. 6.5-2) increasing with increasingsuspended sediment concentration. Definition of the suspended-sediment yields at a site are essential for estimating iron yields from mined and unmined basins. Since runoff from one storm may transport most of the annual sediment load at a site (see section 6.7), sediment and iron transport processes cannot be defined from random and intermittent sampling. Frequent sampling during the full range of flow is necessary to determine iron yields from a basin. 


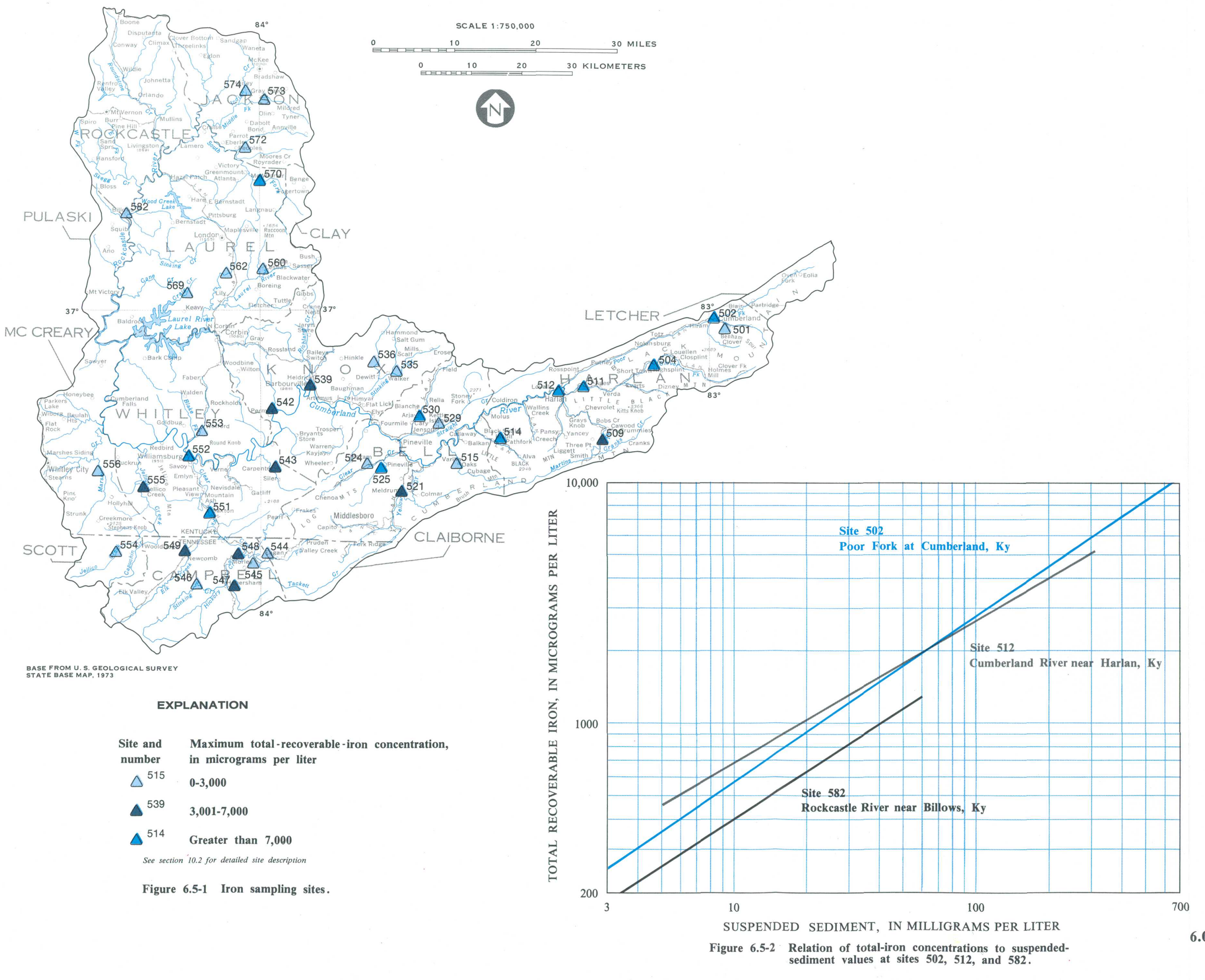

\begin{tabular}{|c|c|c|c|c|c|}
\hline $\begin{array}{l}\text { MAP } \\
\text { NUMBER }\end{array}$ & $\begin{array}{l}\text { NUMBER } \\
\text { OF } \\
\text { SAMPLES }\end{array}$ & $\begin{array}{l}\text { MINIMUNW } \\
\text { (micro }\end{array}$ & $\begin{array}{l}\text { MaXimu } \\
\text { ams per }\end{array}$ & $\begin{array}{l}\text { MEAN } \\
\text { ter) }\end{array}$ & MEDIAN \\
\hline 501 & 6 & 310 & 2600 & 1500 & 1300 \\
\hline 502 & 11 & 30 & 10000 & 2700 & 1100 \\
\hline $\begin{array}{l}504 \\
509\end{array}$ & $\begin{array}{l}6 \\
7\end{array}$ & $\begin{array}{l}300 \\
390\end{array}$ & $\begin{array}{l}7000 \\
6000\end{array}$ & $\begin{array}{l}2190 \\
2200\end{array}$ & $\begin{array}{l}1550 \\
1300\end{array}$ \\
\hline & & 390 & $\begin{array}{r}60600 \\
29000\end{array}$ & $\begin{array}{l}2200 \\
8360\end{array}$ & $\begin{array}{l}\begin{array}{l}13000 \\
3400\end{array} \\
3\end{array}$ \\
\hline 512 & 23 & 10 & 7800 & 1300 & 710 \\
\hline 514 & 6 & 150 & 8500 & 2100 & 720 \\
\hline 515 & 6 & $\begin{array}{l}380 \\
140\end{array}$ & $\begin{array}{l}1700 \\
3400\end{array}$ & $\begin{array}{r}880 \\
1800\end{array}$ & $\begin{array}{r}680 \\
\end{array}$ \\
\hline 524 & $\frac{7}{6}$ & $\begin{array}{l}140 \\
570\end{array}$ & $\begin{array}{l}3400 \\
1200\end{array}$ & $\begin{array}{l}1800 \\
810\end{array}$ & $\begin{array}{r}1800 \\
7725\end{array}$ \\
\hline 525 & 6 & 450 & $\begin{array}{l}126000 \\
4600\end{array}$ & $\begin{array}{l}810 \\
8800\end{array}$ & $\begin{array}{l}723 \\
790\end{array}$ \\
\hline & 6 & 380 & 2100 & 915 & 750 \\
\hline 530 & 6 & $\begin{array}{l}570 \\
830\end{array}$ & $\begin{array}{l}12000 \\
2700\end{array}$ & 2800 & 940 \\
\hline S563 & & $\begin{array}{l}830 \\
740\end{array}$ & $\begin{array}{l}27700 \\
1200\end{array}$ & $\begin{array}{l}1600 \\
6900\end{array}$ & $\begin{array}{r}1700 \\
9 \\
9\end{array}$ \\
\hline 539 & $10^{4}$ & $\begin{array}{l}690 \\
690\end{array}$ & $\begin{array}{l}1200 \\
4600\end{array}$ & $\begin{array}{r}980 \\
2000\end{array}$ & $\begin{array}{r}990 \\
1300\end{array}$ \\
\hline 542 & 10 & 600 & 4300 & 1800 & $\begin{array}{l}1300 \\
1600\end{array}$ \\
\hline 543 & 6 & 650 & 3900 & 1500 & 1150 \\
\hline & & & $\begin{array}{r}1600 \\
750\end{array}$ & $\begin{array}{l}100 \\
53\end{array}$ & $\begin{array}{l}1100 \\
480\end{array}$ \\
\hline 546 & & $\begin{array}{l}4100 \\
290\end{array}$ & $\begin{array}{l}1700 \\
17700\end{array}$ & $\begin{array}{l}330 \\
850\end{array}$ & $\begin{array}{l}\begin{array}{l}480 \\
710\end{array} \\
710\end{array}$ \\
\hline 547 & 4 & 390 & 3100 & 1200 & 600 \\
\hline 548 & & 1300 & 4600 & 2700 & 2400 \\
\hline & 4 & 1100 & 38000 & & $\begin{array}{l}2800 \\
1500\end{array}$ \\
\hline 552 & $\begin{array}{l}11 \\
142\end{array}$ & $\begin{array}{l}410 \\
10\end{array}$ & $\begin{aligned} 242000 \\
12000\end{aligned}$ & $\begin{array}{r}3900 \\
308\end{array}$ & $\begin{array}{r}1500 \\
40\end{array}$ \\
\hline 553 & 5 & 640 & 1000 & 800 & $\begin{array}{l}40 \\
710\end{array}$ \\
\hline 554 & & 680 & 1100 & 930 & 980 \\
\hline $\begin{array}{l}555 \\
556\end{array}$ & 6 & $\begin{array}{l}190 \\
330\end{array}$ & $\begin{array}{c}6800 \\
600\end{array}$ & $\begin{array}{l}1500 \\
550\end{array}$ & 680 \\
\hline 560 & 4 & 1300 & 2100 & $\begin{array}{r}1600 \\
\end{array}$ & 1500 \\
\hline $\begin{array}{l}562 \\
569\end{array}$ & & $\begin{array}{l}750 \\
550\end{array}$ & $\begin{array}{l}1600 \\
1000\end{array}$ & of & 1400 \\
\hline $\begin{array}{l}369 \\
570\end{array}$ & 5 & 630 & $\begin{array}{l}2700 \\
12000\end{array}$ & 3100 & 940 \\
\hline 572 & & 370 & 750 & 550 & 520 \\
\hline $\begin{array}{l}573 \\
574\end{array}$ & ${ }^{5}$ & $\begin{array}{l}270 \\
430\end{array}$ & 740 & $\begin{array}{l}520 \\
460\end{array}$ & $\begin{array}{l}440 \\
-\cdots-\end{array}$ \\
\hline 582 & 19 & 10 & 1000 & 215 & 130 \\
\hline
\end{tabular}

Table 6.5-2 Relation of dissolved and total-recoverableiron concentrations to streamflow at sites
521,552 , and 582 .

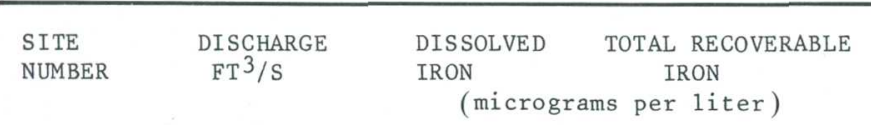

\begin{tabular}{|c|c|c|}
\hline $\begin{array}{c}4.2 \\
8.9 \\
34 \\
92 \\
261\end{array}$ & $\begin{array}{r}160 \\
90 \\
440 \\
50 \\
110\end{array}$ & $\begin{array}{r}1800 \\
3400 \\
860 \\
960 \\
3100\end{array}$ \\
\hline $\begin{array}{r}62 \\
167 \\
330 \\
877 \\
2620 \\
4480 \\
5060\end{array}$ & $\begin{array}{r}50 \\
30 \\
20 \\
140 \\
30 \\
20 \\
30\end{array}$ & $\begin{array}{r}380 \\
670 \\
890 \\
540 \\
1300 \\
12000 \\
4500\end{array}$ \\
\hline $\begin{array}{c}8.0 \\
24 \\
69 \\
181 \\
464 \\
900 \\
1710\end{array}$ & $\begin{array}{r}40 \\
30 \\
120 \\
80 \\
20 \\
100 \\
60\end{array}$ & $\begin{array}{r}250 \\
170 \\
610 \\
320 \\
340 \\
830 \\
1000\end{array}$ \\
\hline
\end{tabular}

6.0 QUALITY OF SURFACE WATER--Continued 6.5 Iron 


\title{
6.0 QUALITY OF SURFACE WATER--Continued 6.6 Manganese
}

\section{Manganese Concentrations are Highest in Streams Draining Mined Basins}

\author{
Manganese concentrations at stream sites in the headwaters of the Cumberland \\ River basin, where coal mining is most intense, are higher than at unmined \\ sites in Area 15. The concentration of manganese does not increase \\ significantly with increasing flow.
}

Manganese is one of the most common elements in soils and rocks. Soils rich in organic matter are one of the main sources of manganese in natural waters. Although dissolved manganese is an essential element for plant and animal metabolism, concentrations in excess of $150 \mu \mathrm{g} / \mathrm{L}$ impart objectionable taste to water and staining of fabrics (U.S. Environmental Protection Agency, 1976).

Most water-supply criteria (U.S. Environmental Protection Agency, 1976) contain maximum limits for dissolved manganese $(50 \mu \mathrm{g} / \mathrm{L})$. The Act specifies $4,000 \mu \mathrm{g} / \mathrm{L}$ as the maximum permissible concentration of total manganese in effluents from mined areas.

Dissolved and total recoverable manganese data are available for 38 sites in Area 15 (fig. 6.6-1 and table 6.6-1). Prior to 1979, data were available for only 6 sites. All of the data available represent intermittent samples with insufficient information to define seasonal flow relations.
Total recoverable manganese concentrations in streams throughout Area 15 range from 20 to 3,800 $\mu \mathrm{g} / \mathrm{L}$. In general, the highest manganese concentrations occur in streams in the Cumberland River basin, where mining is most intense. The lowest values occur at stream sites in the Rockcastle River basin, in Jackson County.

Dissolved manganese constitutes more than half, and in some analyses all, of the total recoverable manganese at most of the sites in Area 15 (table 6.6-2). The data show that the amount of manganese, dissolved and/or suspended, does not change substantially with the amount of streamflow. Determination of manganese loads can only be achieved by frequent sampling. The lack of any significant correlation between manganese and other water-quality parameters, such as specific conductance, indicates that load estimates in streams cannot be obtained except by frequent and intense sampling throughout the full range of streamflows. 


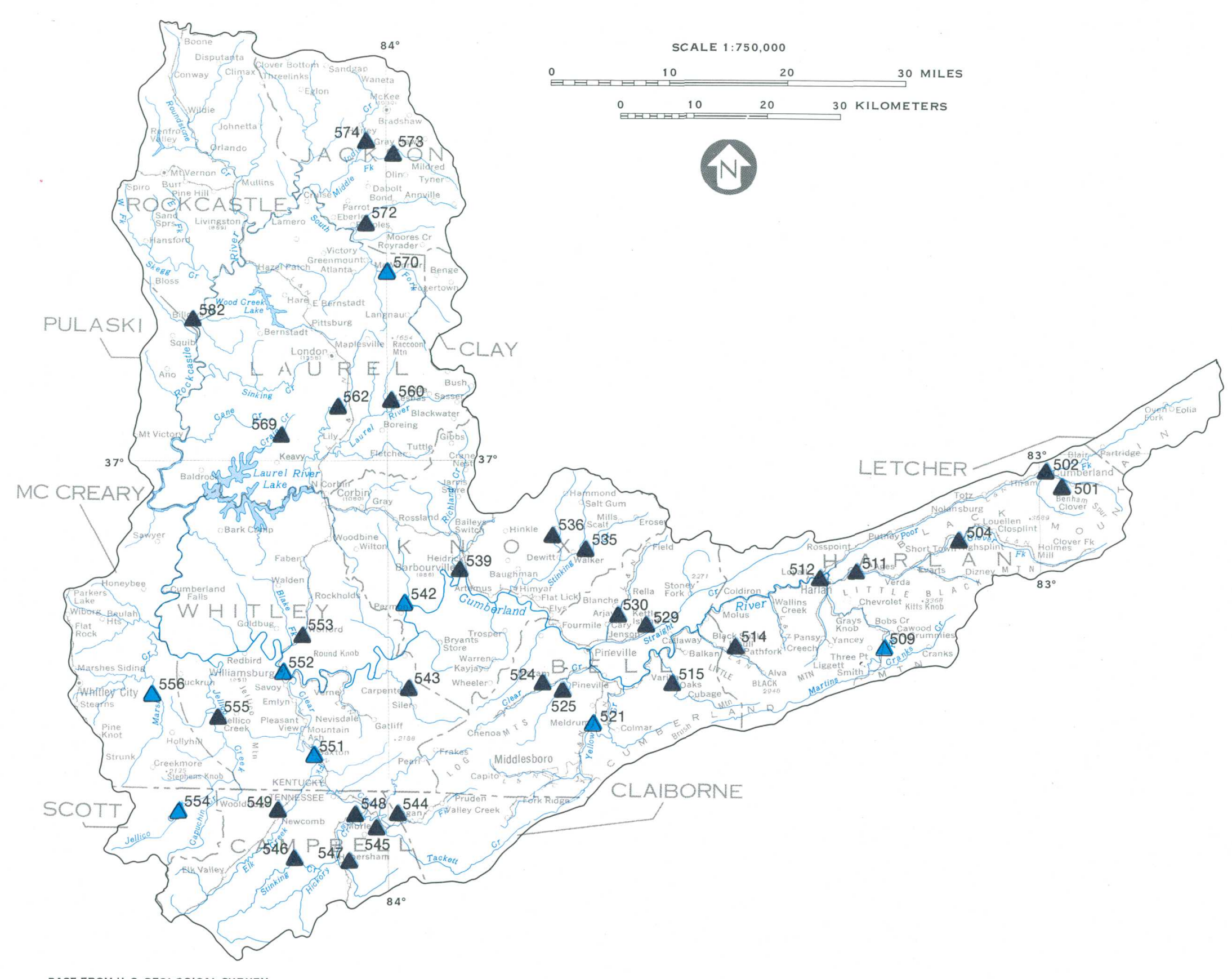

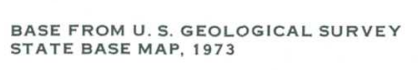

EXPLANATION

$$
\begin{array}{rl}
\begin{array}{l}
\text { Site location } \\
\text { and number }
\end{array} & \begin{array}{l}
\text { Maximum-total-recoverable- } \\
\text { manganese concentrations, } \\
\text { in micrograms per liter }
\end{array} \\
\Delta^{535} & \mathbf{0 - 9 9 9} \\
\Delta^{570} & \text { Greater than 1,000 }
\end{array}
$$

\begin{tabular}{|c|c|c|c|c|c|}
\hline $\begin{array}{c}\text { SITE } \\
\text { NUMBER }\end{array}$ & $\begin{array}{l}\text { NUMBER OF } \\
\text { OBSERVATIONS }\end{array}$ & $\underset{\text { (micr }}{\text { MINIMUM }}$ & $\begin{array}{l}\text { MAXIMUM } \\
\text { grams per }\end{array}$ & $\begin{array}{c}\text { MEDTAN } \\
\text { iiter) }\end{array}$ & MEAN \\
\hline 501 & 6 & $\begin{array}{l}70 \\
50\end{array}$ & $\begin{array}{l}240 \\
370\end{array}$ & 130 & 145 \\
\hline $\begin{array}{l}502 \\
504\end{array}$ & $\begin{array}{r}11 \\
6\end{array}$ & $\begin{array}{l}50 \\
40\end{array}$ & $\begin{array}{l}370 \\
180\end{array}$ & $\begin{array}{l}90 \\
60\end{array}$ & $\begin{array}{c}124 \\
75\end{array}$ \\
\hline 509 & 7 & $\begin{array}{l}40 \\
50\end{array}$ & $\begin{array}{l}100 \\
1400\end{array}$ & 180 & 338 \\
\hline $\begin{array}{l}511 \\
512\end{array}$ & $\begin{array}{r}6 \\
13\end{array}$ & $\begin{array}{l}50 \\
70\end{array}$ & $\begin{array}{l}710 \\
220\end{array}$ & $\begin{array}{l}115 \\
110\end{array}$ & $\begin{array}{l}240 \\
128\end{array}$ \\
\hline $\begin{array}{l}512 \\
514\end{array}$ & $\begin{array}{r}13 \\
6\end{array}$ & 30 & $\begin{array}{l}210 \\
190\end{array}$ & $\begin{array}{r}110 \\
50\end{array}$ & $\begin{array}{r}128 \\
77\end{array}$ \\
\hline $\begin{array}{l}514 \\
515\end{array}$ & 6 & 150 & 300 & 250 & 233 \\
\hline 521 & 37 & & 3800 & 405 & $\begin{aligned} & 353 \\
& 487\end{aligned}$ \\
\hline 524 & 6 & 30 & 110 & 60 & 67 \\
\hline 525 & 6 & $\begin{array}{l}40 \\
300\end{array}$ & 790 & 50 & 183 \\
\hline $\begin{array}{l}529 \\
530\end{array}$ & 6 & $\begin{array}{l}390 \\
130\end{array}$ & $\begin{array}{l}800 \\
450\end{array}$ & $\begin{array}{l}530 \\
250\end{array}$ & $\begin{array}{r}570 \\
273\end{array}$ \\
\hline 535 & 5 & 70 & 500 & 180 & 226 \\
\hline $\begin{array}{l}536 \\
539\end{array}$ & $\begin{array}{r}4 \\
12\end{array}$ & $\begin{array}{l}80 \\
70\end{array}$ & $\begin{array}{l}470 \\
260\end{array}$ & & \\
\hline 542 & 6 & 520 & 1300 & 625 & 758 \\
\hline 543 & 6 & 260 & 570 & 460 & 433 \\
\hline $\begin{array}{l}544 \\
545\end{array}$ & $3_{3}^{3}$ & $\begin{array}{l}210 \\
110\end{array}$ & $\begin{array}{l}460 \\
450\end{array}$ & 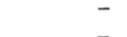 & \\
\hline 546 & 4 & & & & \\
\hline & 3 & 30 & 430 & - & - \\
\hline 548 & 4 & 330 & 930 & - & - \\
\hline 549 & 4 & 290 & 580 & & \\
\hline 552 & $\begin{array}{l}130 \\
20\end{array}$ & 60 & 1400 & 140 & $\begin{array}{l}461 \\
245\end{array}$ \\
\hline & & 100 & 230 & 180 & 172 \\
\hline 554 & 4 & 510 & 1600 & & - \\
\hline 555 & 7 & 130 & 700 & 310 & 318 \\
\hline $\begin{array}{l}536 \\
560\end{array}$ & & $\begin{array}{l}200 \\
150\end{array}$ & $\begin{array}{l}1300 \\
250\end{array}$ & & \\
\hline 562 & & 200 & 920 & & \\
\hline 569 & 6 & 30 & 430 & 90 & 187 \\
\hline 570 & & 160 & 1100 & 290 & 430 \\
\hline $\begin{array}{l}512 \\
552\end{array}$ & & 30 & & & \\
\hline 574 & 3 & 160 & 270 & - & 150 \\
\hline 582 & 10 & 40 & 170 & 85 & 95 \\
\hline
\end{tabular}

See section 10.2 for deaailed site descripion

\begin{tabular}{|c|c|c|c|}
\hline 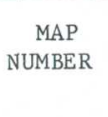 & $\begin{array}{l}\text { DISCHARGE } \\
(\mathrm{ft}(3) / \mathrm{s})\end{array}$ & $\begin{array}{l}\text { DISSOLVED } \\
\text { MANGANESE } \\
\text { (microgram }\end{array}$ & $\begin{array}{l}\text { TOTAL RECOVERABLE } \\
\text { MANGANESE } \\
\text { sper liter) }\end{array}$ \\
\hline 521 & $\begin{array}{c}4.2 \\
8.9 \\
34 \\
92 \\
261\end{array}$ & $\begin{array}{l}300 \\
440 \\
240 \\
140 \\
150\end{array}$ & $\begin{array}{l}330 \\
490 \\
240 \\
140 \\
210\end{array}$ \\
\hline 552 & $\begin{array}{r}62 \\
167 \\
330 \\
877 \\
2620 \\
4480 \\
5060\end{array}$ & $\begin{array}{r}70 \\
60 \\
80 \\
50 \\
100 \\
110 \\
110\end{array}$ & $\begin{array}{r}90 \\
110 \\
110 \\
60 \\
140 \\
540 \\
240\end{array}$ \\
\hline 582 & $\begin{array}{c}8.0 \\
24 \\
69 \\
181 \\
464 \\
900 \\
1710\end{array}$ & $\begin{array}{l}70 \\
70 \\
40 \\
20 \\
10 \\
20 \\
80\end{array}$ & $\begin{array}{r}150 \\
90 \\
40 \\
60 \\
80 \\
80 \\
110\end{array}$ \\
\hline
\end{tabular}

See section 10.2 for detailed site description

Table 6.6-2 Relation of dissolved and total-recoverable-manganese concentrations to streamflow at sites 521,552 , and 582 .

6.0 QUALITY OF SURFACE WATER--Continued 6.6 Manganese 


\title{
6.0 QUALITY OF SURFACE WATER--Continued 6.7 Sediment
}

\section{Suspended-Sediment Data Limited}

\author{
Suspended-sediment data are collected two to five times per week and during \\ storms at six sites, and at three-month intervals at 32 sites in Area 15.
}

Frequent sampling during the full range of flow is necessary to determine suspended-sediment yield from a basin. Sediment transport processes cannot be defined from random and intermittent sampling, since one storm may transport most of the annual sediment load at a site. Only limited sediment data were collected in Area 15 prior to 1979, although suspended-sediment samples were occasionally collected at streamflow sites during storm-discharge measurements.

In response to the Act, the collection of suspended-sediment data was expanded in 1979 to 38 sites (fig. 6.7-1). At six sites, samples are collected two to five times each week and during storms. Data from these sites will be used to compute daily and annual suspended-sediment loads. At 32 sites, samples are collected at three-month intervals, during various flow conditions, in order to define a preliminary suspended-sediment transport curve to estimate sediment loads.

The data collected during $1979-80$ show that the transport of suspended sediment in Area 15 is affected by seasonal precipitation and intensity of mining. Comparison of suspended-sediment transport curves for sites 512 and 552 in the Cumberland River basin (fig. 6.7-2) shows that the suspended-sediment yields are about 10 times higher during May to November than during December to April. More frequent and intense storms occur in the basin during the summerfall months than during the winter months. Similar seasonal patterns in the transport of suspended sediment have been observed in other coal basins in eastern Kentucky (Quinones and others, 1981).

The effects of surface mining on the suspendedsediment transport are evident from a comparison of the transport curves between several sites in Area 15 (fig. 6.7-3). Suspended-sediment yields in the heavily mined Yellow Creek basin (site 521) are from five to ten times higher than in the Rockcastle River basin (site 582), which is largely forested and undisturbed. Yields in the Clover Fork basin (site 511) are affected by water impoundments that cover about 20 percent of the drainage area.

The transport of most of the annual suspendedsediment load at sites in Area 15 can occur during one intense storm (fig. 6.7-4). The suspended-sediment load transported during the March 20-21 storm at Yellow Creek near Middlesboro (site 521) accounted for about 60 percent of the annual suspendedsediment load during 1980. 


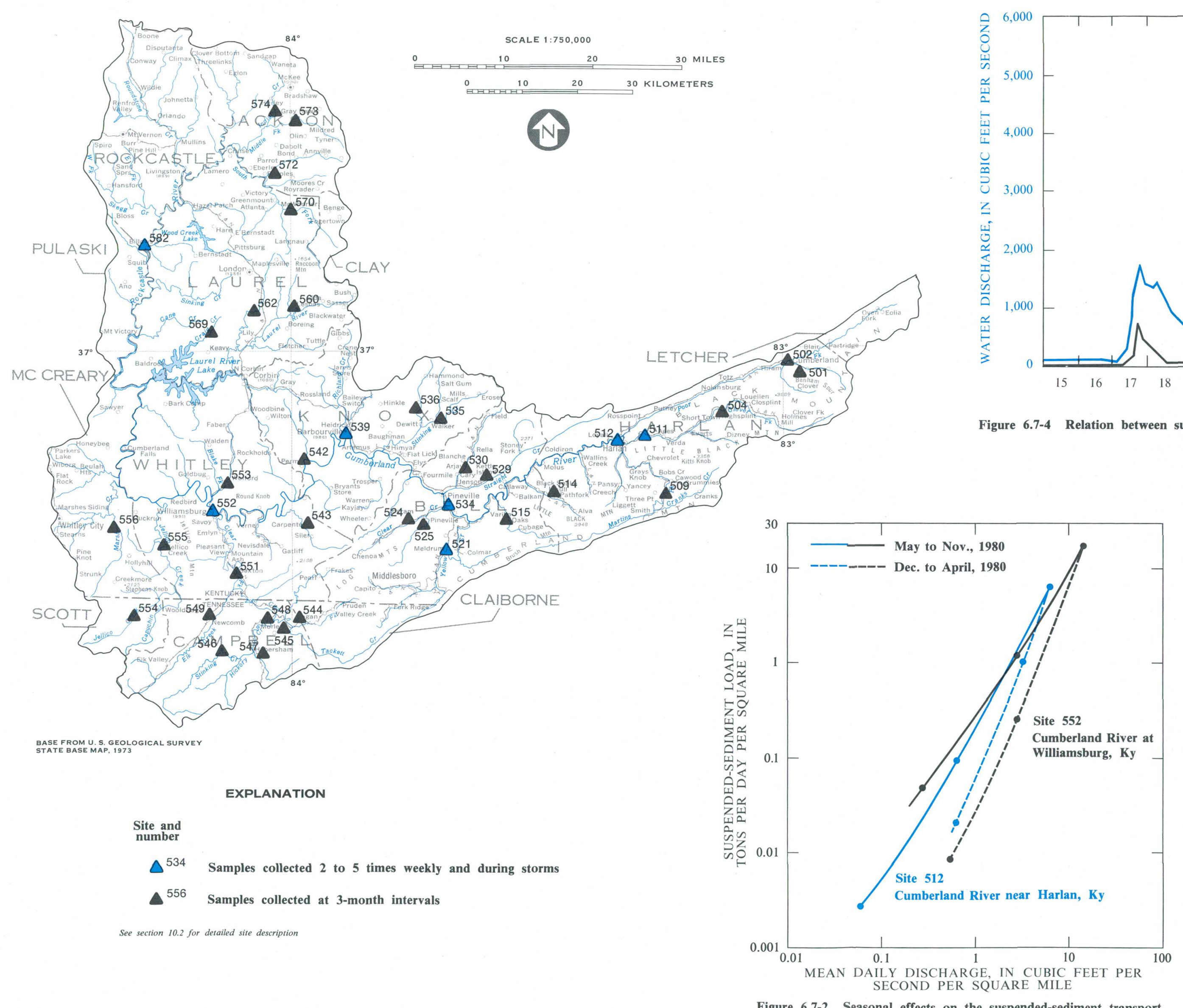

Figure 6.7-1 Suspended-sediment sampling sites.
Figure 6.7-2 Seasonal effects on the suspended-sediment transport.

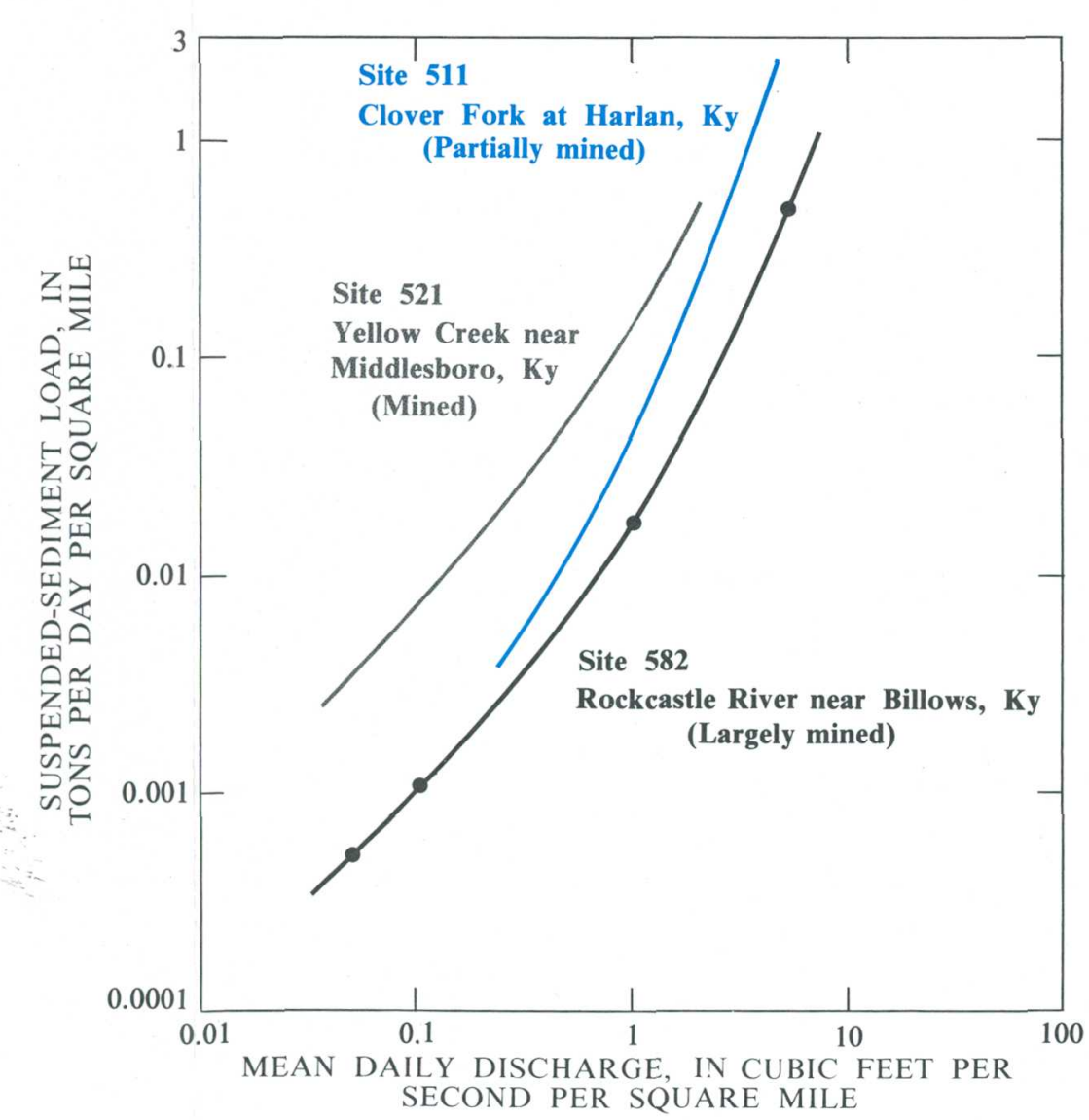

Figure 6.7-3 Relation between instantaneous water disharge and suspended-sediment loads at partially mined and tus 6.0 QUALITY OF SURFACE WATER--Continued 


\title{
6.0 QUALITY OF SURFACE WATER--Continued \\ 6.8 Trace Constituents
}

\section{Most Concentrations of Trace Constituents in Water and Bottom Material Were Low}

\author{
Concentrations of dissolved mercury at selected sites in Area 15 exceed \\ maximum recommended State and Federal limits for water for aquatic life. \\ Low concentrations of trace constituents were found in streams and in \\ stream bottom material in Area 15. Data available are not adequate \\ to define transport of trace constituents.
}

Trace constituents are predominantly metals of low solubility. They normally occur in low concentrations in natural water. In low concentrations most of the constituents are essential to life. However, in high concentrations some are toxic to plants and animals. Trace constituents are present in soils and rocks and under normal weathering conditions slowly leach into natural waters. High concentrations of trace metals in water are usually associated with industrial-waste discharges and acid-mine drainage.

The oxidation of minerals containing sulfur in mining spoils produces sulfuric acid. The acid accelerates the leaching of minerals and dissolution of salts. These processes may increase the dissolvedsolids and the trace-constituents concentration in water. Mine drainage, particularly when acidic, usually contains concentrations of trace constituents that exceed background levels. When mine-drainage is neutralized, trace constituents may precipitate and concentrate in stream-bottom deposits.

Concentrations of selected constituents in water and stream-bottom sediments at sites in Area 15 (fig. 6.8-1) are shown in tables 6.8-1 and 6.8-2. The samples were collected during low-flow periods during 1979-80.

The available data show that trace constituents are not present in significant concentrations in water, or in the stream-bottom sediments at the sampled sites. Dissolved mercury concentrations at some sites exceed State and.Federal maximum-recommended concentrations of $0.05 \mu \mathrm{g} / \mathrm{L}$ for aquatic life (U.S. Environmental Protection Agency, 1976). None of the streams contained more than $2.0 \mu \mathrm{g} / \mathrm{L}$ of mercury, which is the maximum recommended concentration for domestic water supply. Iron and manganese concentrations in bottom sediments of streams draining mined areas are higher than those at other sites in Kentucky where no mining occurs (U.S. Geological Survey, 1980).

The transport of trace constituents in areas affected by mining is generally associated with the transport of suspended sediment. The data in Area 15 , however, are not adequate to define these relations. An intensive program involving time and stage sampling is required to define these processes. 
Table 6.8-1 Trace constituents, in bottom sediments.

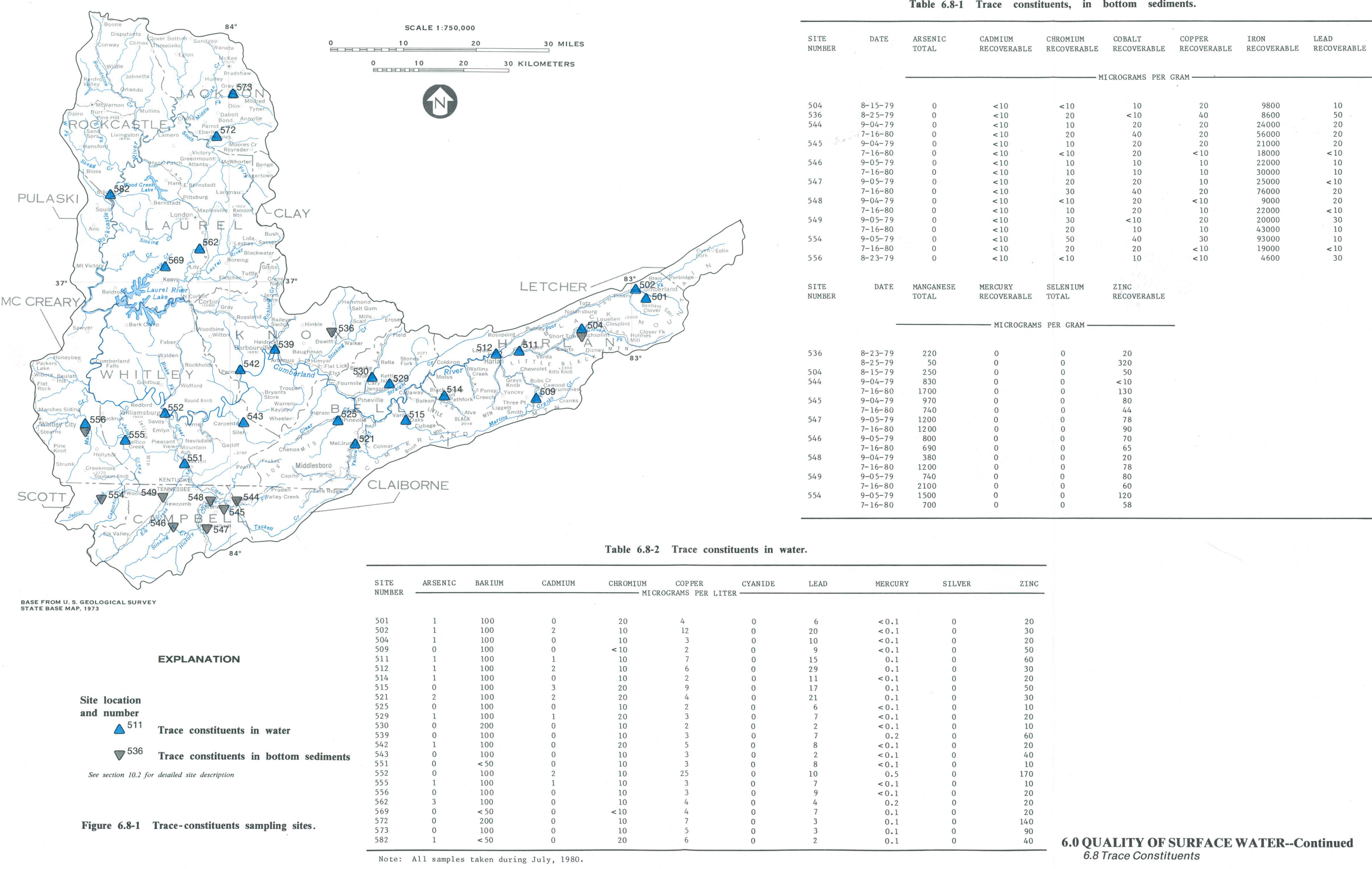




\author{
7.0 GROUND WATER \\ 7.1 Occurence, Movement, Recharge, and Discharge
}

\title{
Aquifers Recharged by Precipitation
}

\author{
Multiple sandstone aquifers are present in the Breathitt and Lee Formations \\ in Area 15. They are recharged by precipitation and discharge to springs \\ and streams.
}

\begin{abstract}
Almost all ground water in Area $\mathbf{1 5}$ originates as precipitation that percolates downward to the zone of saturation, the upper surface of which is called the water table. The water table generally follows the shape of the land surface but is not as deep under valleys as under hilltops. Multiple aquifers can underlie the same area and each aquifer can have its own potentiometric surface or artesian head (fig. 7.1-1).
\end{abstract}

An artesian (confined) aquifer can occur between less permeable beds (shale and underclay). The water level in a well tapping an artesian aquifer rises above the top of the aquifer. Nearly all ground water in Area 15 is under artesian pressure.

A perched aquifer may be separated from the main water table by less permeable rocks that interrupt percolation and cause water to accumulate in an upper stratum. These occurences are in the hilly terrain underlain by alternating beds of permeable sandstone and less permeable rocks (fig. 7.1-1). Perched aquifers are easily altered by earth-moving operations such as strip mining or road construction.

Ground water is stored in and moves through intergranular and fracture openings in rocks. Most of the ground water in Area 15 comes from fracture openings that have developed in sandstone aquifers in the Breathitt and Lee formations. In the northwest part of the area, and along the northern slope of Pine Mountain, solutionally enlarged fracture openings in limestones of pre-Pennsylvanian age permit relatively free movement of large quantities of ground water to wells and springs.

Regionally, little is known about the direction of ground-water movement. Movement of water is from areas of high to areas of low pressure and is generally downdip along bedding planes. In the Middlesboro Syncline water moves to the center of the basin from Pine Mountain and Cumberland Mountain. Locally water may move in different directions because of influences of topography, impermeable beds, and the orientation of fracture systems. The rate of movement depends on the size and interconnection of water bearing openings and the hydraulic gradient.

Direct infiltration of precipitation is the major source of recharge to upper aquifers (fig. 7.1-1). Lower aquifers are recharged by leakage from overlying aquifers and to a lesser extent by direct infiltration of precipitation. Some water is contributed by streams that flow over the outcrop of the aquifer, provided the water table is below stream level. Recharge from streams can be large where the streams cross an aquifer that has been extensively fractured.

All ground water is in motion from areas of recharge to areas of discharge. Water discharges downward from areas of recharge and laterally to the outcrop as seeps or springs on hillsides (fig. 7.1-1). Water from lower aquifers moves downward, laterally, or upward to become streamflow. Pumping wells can alter the water levels in nearby wells or streams. 


\section{EXPLANATION}

$\therefore$

Colluvium and alluvium fill in valley

Water table (wet weather)

Water table (dry weather)

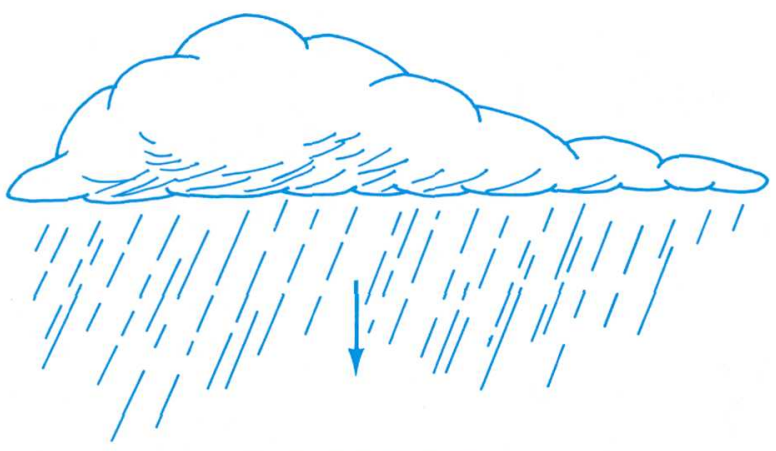

PRECIPITATION

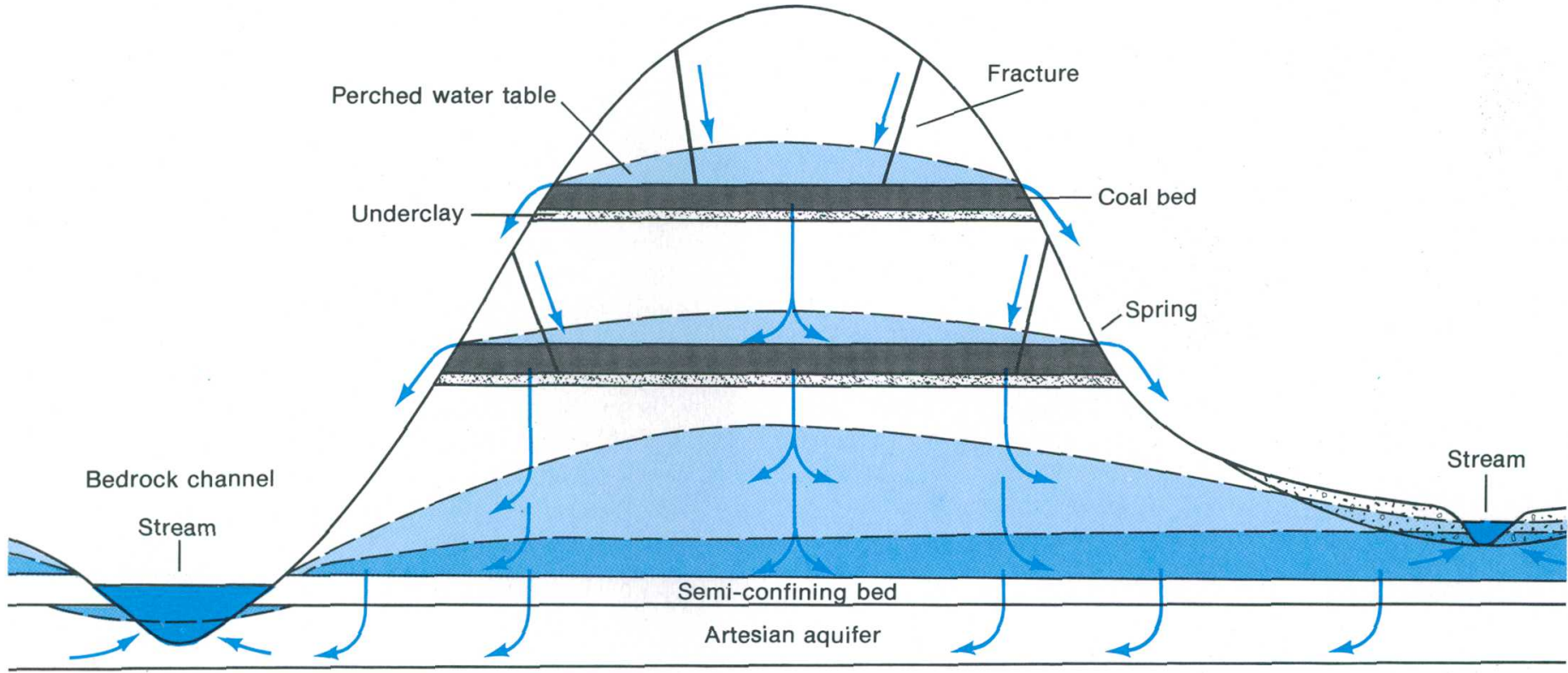

Figure 7.1-1 Generalized storage and movement of ground water. 


\title{
7.0 GROUND WATER--Continued \\ 7.2 Water Levels
}

\section{Water Levels Fluctuate Seasonally}

\author{
Water-level fluctuations reflect seasonal variations in the rate of recharge \\ to, and discharge from aquifers in Area 15. Water levels range from above \\ land surface to as much as 300 feet or more below land surface.
}

Water levels in Area 15 fluctuate in response to recharge and discharge of ground water. The principal factors affecting water levels are precipitation, evapotranspiration, natural discharge, and pumping from wells. During the growing season plants intercept water before it can enter the zone of saturation. Evapotranspiration causes a decline in water levels during the growing season as discharge continues to be greater than recharge. The lowest water levels occur in the fall prior to the first killing frost. During the winter months evapotranspiration decreases and water levels rise as recharge exceeds discharge. The highest water levels usually occur in the spring prior to the onset of the growing season.

Long-term ground-water level data are available from four wells in Area 15. Water levels for a 5-year period for one of the wells, tapping Pennsylvanian rocks, are shown in the hydrograph, figure 7.2-1. Based on this hydrograph, there are no long-term rising or falling water level trends. The hydrograph for the 1979 water year shows typical ground-water level response to seasonal variations in recharge and precipitation at a nearby station. The peaks in the ground water record are caused when recharge from precipitation exceeds discharge from the aquifers with individual peaks caused by isolated periods of precipitation. The range in water-level fluctuations for the period of record is about 13 feet. The fluctuation can vary from place to place and may be considerably different in other parts of the area. Water-level fluctuations greater than 13 feet are typical in the limestone rocks of pre-Pennsylvanian age in Area 15. Water levels are more variable in these limestone rocks due to faster recharge and discharge through solution openings.

The depth to water is generally less than 50 feet under valleys and may be as much as 300 feet under ridges. However, the depth to water may be considerably less where perched water zones occur under ridges. Flowing wells are fairly common in the Middlesboro Syncline.

Continous water-level records for observations wells in Area 15 may be obtained from the U.S. Geological Survey at Louisville or from the series of annual reports "Water Resources Data for Kentucky", published by the U.S. Geological Survey. Hydrographs of water levels in observation wells through 1976 are published in Whitesides and others (1978). 


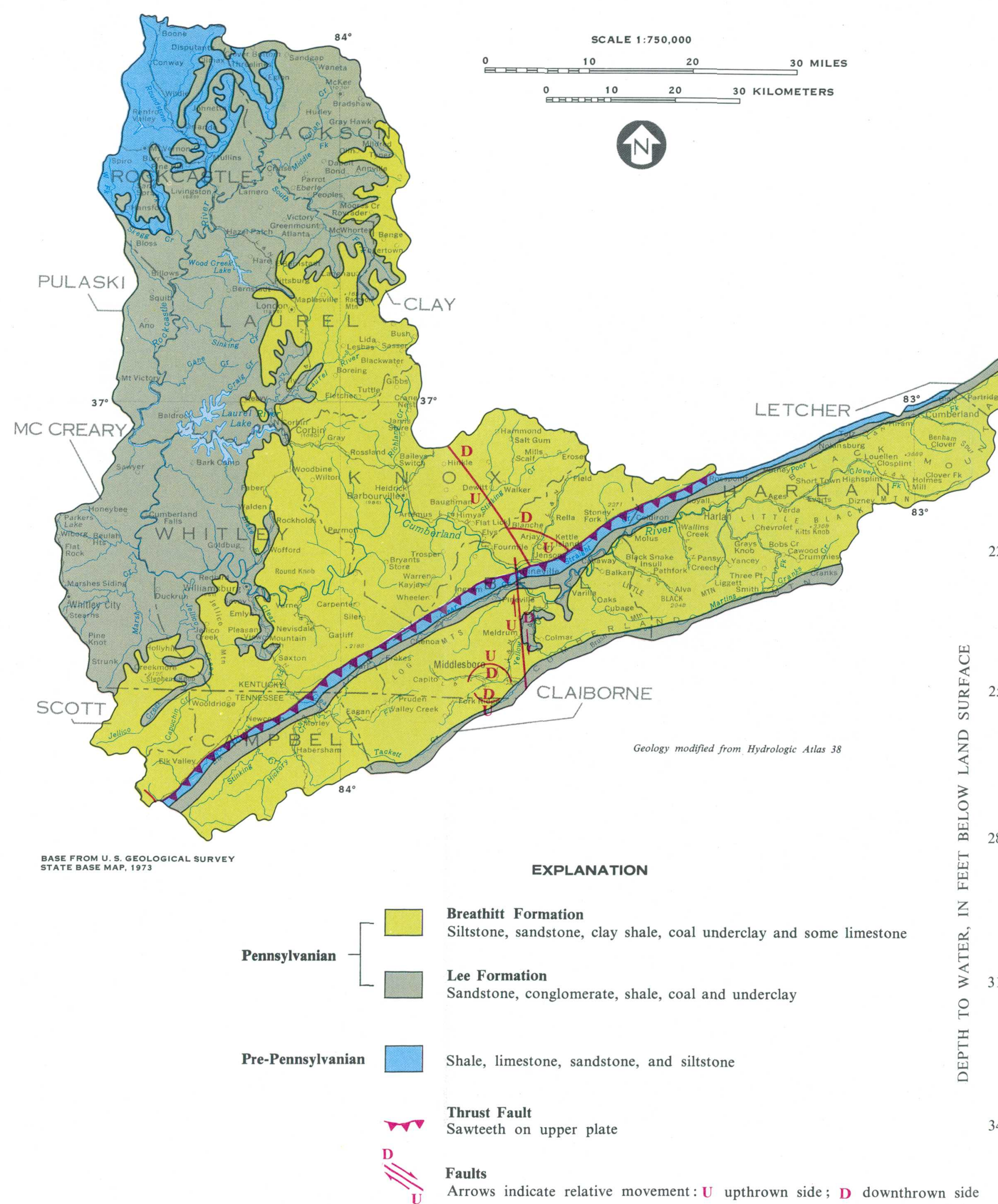

Figure 7.2-1 Water-level fluctuations.
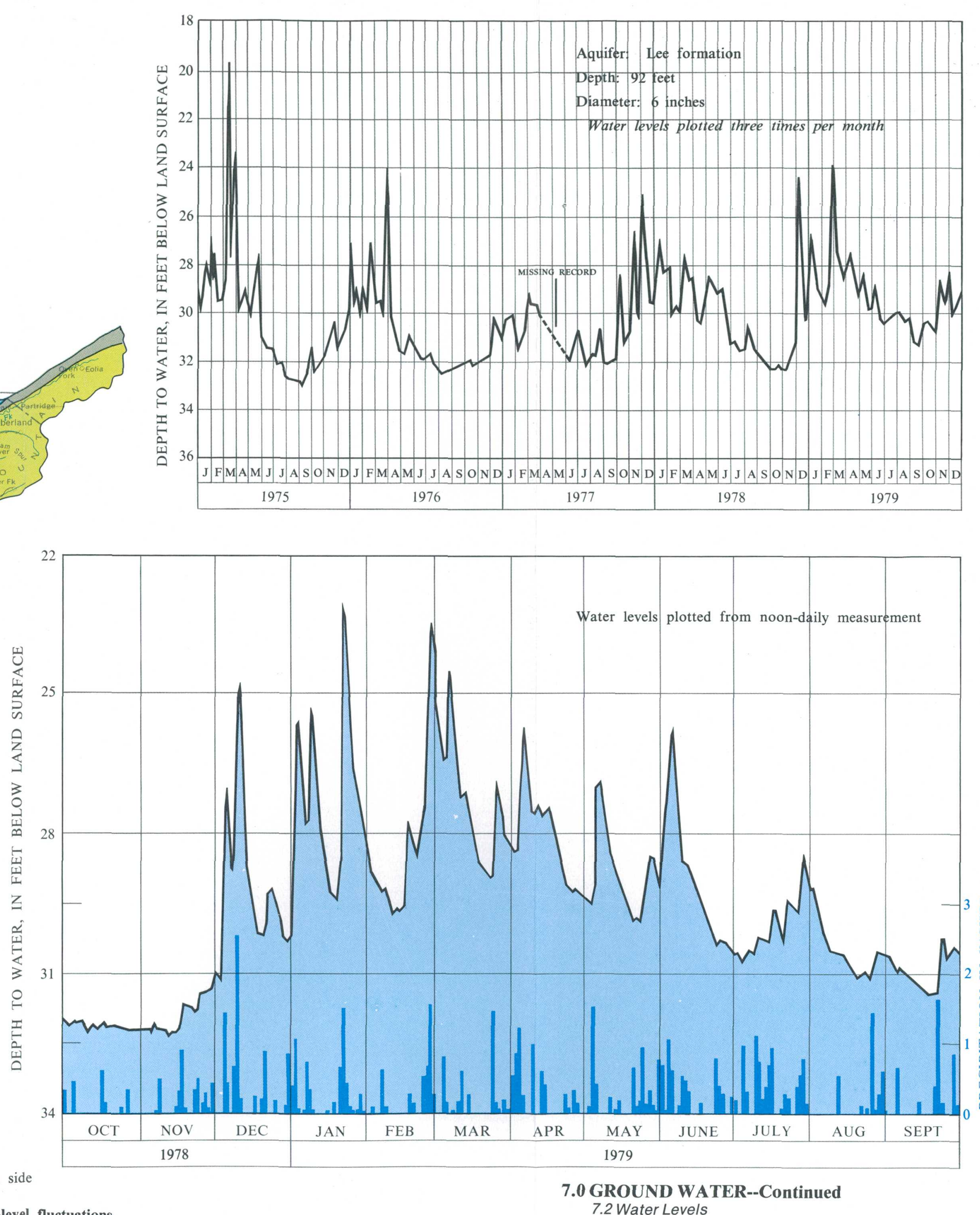

.0 GROUND WATER--Continued 


\title{
7.0 GROUND WATER--Continued \\ 7.3 Yield's to Wells
}

\section{Measured Yields to Wells Range from 1 to 250 Gallons Per Minute}

\author{
Pennsylvanian rocks yield from 1 to 250 gallons per minute to wells \\ depending on location and well depth. Pre-Pennsylvanian rocks \\ generally yield less than 50 gallons per minute to wells.
}

The principal factors governing well yields are well depth, location, lithology of the rocks tapped, and fractures. In general, deeper wells have greater yields. However, fractures are generally fewer in number and smaller at greater depths. Hence, greater depths may not necessarily produce a corresponding increase in yield.

The main sources of ground water in Area 15 are the Breathitt and Lee Formations of Pennsylvanian age (fig. 7.3-1). Sandstone is the principal aquifer but shale and coal deposits also yield water to wells. Yields usually range from less than 1 to $25 \mathrm{gal} / \mathrm{min}$ from wells 200 feet or less in depth. Yields as much as $250 \mathrm{gal} / \mathrm{min}$ are known from fractured sandstones of the Lee Formation near the Pine Mountain Fault in Harlan County. Similar yields may be obtained in the vicinity of other major faults because fractures tend to be larger and more numerous near fault zones. Yields as much as $250 \mathrm{gal} / \mathrm{min}$ are known from wells tapping sandstone of the Lee Formation
600 feet below the valleys of perennial streams. Deep wells (about 1,000 feet) tapping the Lee Formation in the Middlesboro Syncline flow as much as $15 \mathrm{gal} / \mathrm{min}$ (Mull and Pickering, 1969). Possibly the yields from depths greater than $\mathbf{3 0 0}$ feet are from intergranular pore spaces where sandstone particles are poorly cemented (Price and others, 1962).

The availability of ground water in pre-Pennsylvanian rocks is related to well depth, topography, rock type, and the character of the overlying Pennsylvanian rocks. The major aquifers are limestone rocks that may yield more than $50 \mathrm{gal} / \mathrm{min}$ from interconnected, solution openings. Springs may flow more than $20 \mathrm{gal} / \mathrm{min}$ from similar openings. Yields generally range from less than 1 to more than 50 $\mathrm{gal} / \mathrm{min}$, but typically are less than $1 \mathrm{gal} / \mathrm{min}$ where limestone above stream level is overlain by shale or siltstone of Pennsylvanian age. 


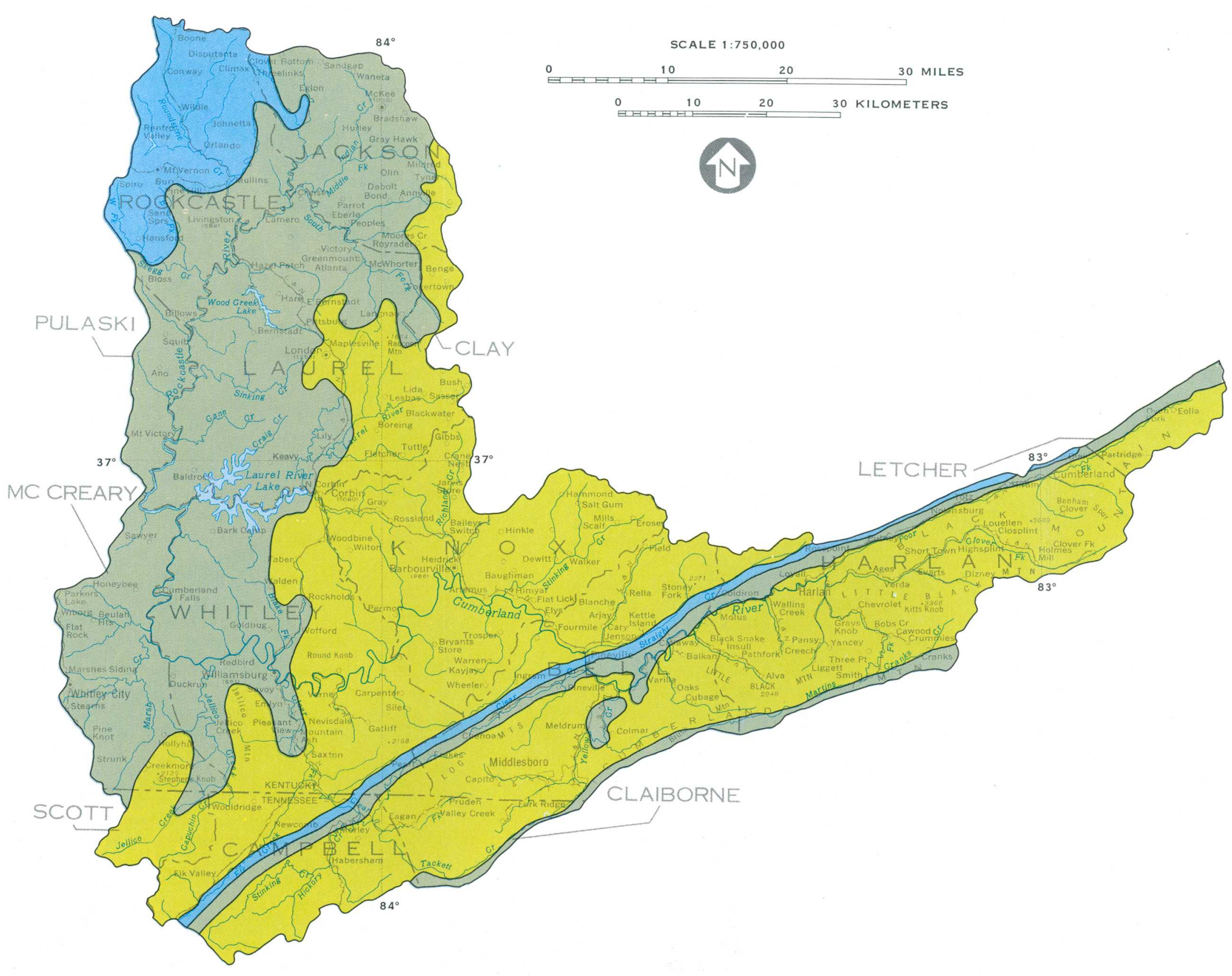

EXPLANATION

Yield to wells

(in gallons per minute)

\section{Breathitt formation}

Lee formation

less than 1 to 250

Pre-Pennsylvanian rocks

less than 1 to more than 50

BASE FROM U.S. SEFLOOGICAL SURVEY
STATE BASE MAP, 1973 


\title{
8.0 QUALITY OF GROUND WATER
}

\section{Chemical Quality of Ground Water is Highly Variable}

\author{
Ground water in Area 15 is generally suitable for most uses, although \\ treatment is required for some uses. High iron concentrations in water \\ are common and hardness ranges from soft to very hard.
}

The quality of ground water in Area 15 is highly variable, but is generally acceptable for most uses with proper treatment. There are not enough chemical analyses available to adequately define the chemical characteristics of ground water in Pennsylvanian aquifers throughout Area 15 and there are no chemical analyses from pre-Pennsylvanian aquifers.

Available minimum, median, and maximum values for the concentration of common chemical constituents in the Breathitt and Lee formations are shown in figure 8.0-1. Most water analyses from the Breathitt Formation are from Bell County. Median values are shown because they are more representative than average or extreme values, especially in the Lee Formation where brines and brackish water occur. Waters with specific conductance values greater than $10,000 \mu \mathrm{mhos} / \mathrm{cm}$ were considered to be unsuitable for domestic use and were not used in compiling the water-quality table in figure 8.0-1. Ground-water quality data for Kentucky have been compiled by Faust and others (1980).

Water having more than $1,000 \mathrm{mg} / \mathrm{L}$ dissolved solids,(Hopkins, 1966) in Area 15 is found at depths more than about 300 feet below valleys except in areas adjacent to major faults and in the Middlesboro Syncline. For example, Hopkins (1966) reported only $2 \mathrm{mg} / \mathrm{L}$ of chloride in water from two wells that were reported to be 1,500 feet deep near a fault area in Bell County. Fresh water at such depth probably occurs in fractures related to the Pine Mountain overthrust fault. Saline water occurs at depths less than 100 feet below the level of the deeper valleys in non-faulted areas, such as in Knox, Laurel, and Whitley Counties. It is common in the vicinity of oil and gas fields because saline water can migrate upward through improperly plugged or abandoned oil, gas, or test wells. In general, the concentration of dissolved solids increases with depth, and water classified as brines (more than $35,000 \mathrm{mg} / \mathrm{L}$ dissolved solids) can be found at depths greater than $1,000 \mathrm{ft}$ in any part of the area. Sodium and chloride are the main constituents of the saline water.

Iron is generally the second most common constituent found in ground water which may limit its use in Area 15. The dissolved-iron concentrations range from 0.003 to $25 \mathrm{mg} / \mathrm{L}$. Water from coal mines or water that has drained through beds of black shale is most likely to have high concentrations of iron (Price and others, 1962). Locally, water from all formations in the area may contain concentrations of iron in excess of the $0.3 \mathrm{mg} / \mathrm{L}$ recommended limit for water for domestic use (U.S. Environmental Protection Agency, 1977).

Hardness is also frequently troublesome in ground water from Area 15. Hardness in water from rocks of Pennsylvanian age ranges from 5 to 790 $\mathrm{mg} / \mathrm{L}$. Hardness shows little relation to depth or location of wells.

Most waters from rocks of Pennsylvanian age in Area 15 can be classified as calcium magnesium bicarbonate, sodium bicarbonate or sodium sulfate types. None of these types is unique to either the Breathitt or Lee Formation. All types occur in each formation. The principal factors that govern the chemical quality of ground water are rock type and the amount of time water has been in contact with the rocks. Water from deep wells tends to be more highly mineralized than water from shallow wells or springs, because of the greater time the water has been in contact with rocks. Water from wells near hilltops is usually less mineralized than water from wells in valleys. In places where coal and black shale are relatively close to the surface, water in these rocks tends to have $\mathrm{pH}$ values less than 7.0 units. 

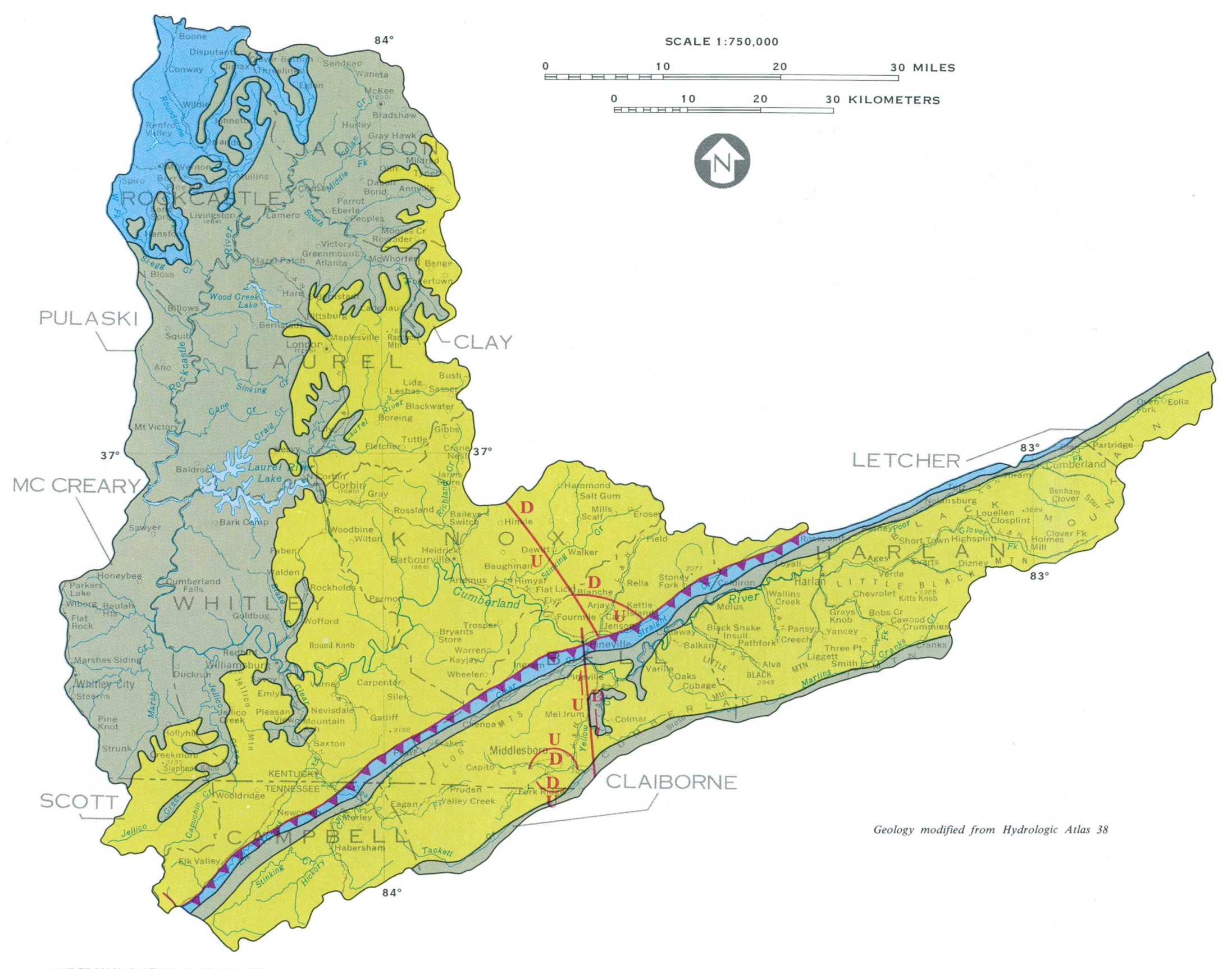

BASE FROMU.S.S. GEDLOGICAL SURVEY
STATE BASE MAP, I

\section{EXPLANATION}

Table 8.0-1 Summary of analyses of ground water in Area 15.

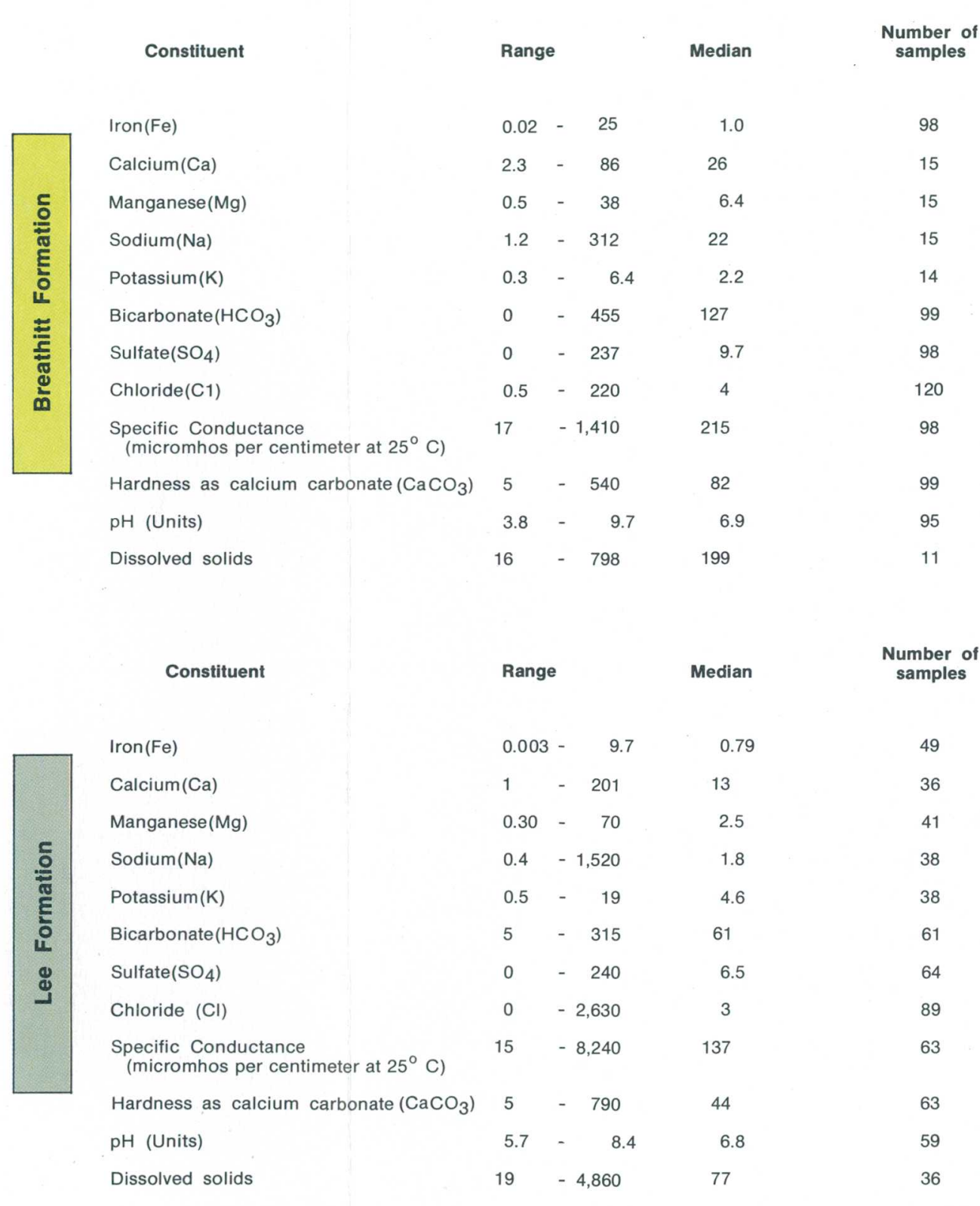

Pennsylvanian $-\begin{array}{ll}\square & \begin{array}{l}\text { Breathitt Formation } \\ \text { Siltstone, sandstone, clay shale, coal underclay and some limestone }\end{array} \\ \square & \begin{array}{l}\text { Lee Formation } \\ \text { Sandstone, conglomerate, shale, coal and underclay }\end{array}\end{array}$

Pre-Pennsylvanian

\section{Thrust Fault}

Faults

Faults
Arrows indicate relative movement : U upthrown side; D downthrown side

Figure 8.0-1 Generalized geology 


\title{
9.0 WATER-DATA SOURCES \\ 9.1 Introduction
}

\section{NAWDEX, WATSTORE, and OWDC Information}

\author{
Water data are collected in coal areas by large number of \\ organizations in response to a wide variety of missions and needs.
}

Within the U.S. Geological Survey there are three activities that help to identify and improve access to the vast amount of existing water data. These activities are:

(1) The National Water Data Exchange (NAWDEX), which indexes the water data available from over 400 organizations and serves as a central focal point to help those in need of water data to determine what information is available.

(2) The National Water Data Storage and Retrieval System (WATSTORE), which serves as the central repository of water data collected by the U.S. Geological Survey and which contains large volumes of data on the quantity and quality of both surface and ground waters.

(3) The Office of Water Data Coordination (OWDC), which coordinates Federal water-data acquisition activities and maintains a "Catalog of Information on Water Data." To assist in identifying available water-data activities in coal provinces of the United States, special indexes to the Catalog are being printed and made available to the public.

A more detailed explanation of these three activities are given in sections 9.2, 9.3, and 9.4. 


\title{
9.0 WATER-DATA SOURCES--Continued 9.2 National Water Data Exchange (NAWDEX)
}

\section{NA WDEX Simplifies Access to Water Data}

\author{
The National Water-Data Exchange (NAWDEX) is a nationwide \\ program managed by the U.S. Geological Survey to \\ assist users of water data or water-related data \\ in identifying, locating, and acquiring needed data.
}

NAWDEX is a national confederation of wateroriented organizations working together to make their data more readily accessible and to facilitate a more efficient exchange of water data.

Services are available through a Program Office located at the U.S. Geological Survey's National Center in Reston, Virginia, and a nationwide network of Assistance Centers located in 45 states and Puerto Rico, which provide local and convenient access to NAWDEX facilities (fig. 9.2-1). A directory is available on request that provides names of organizations and persons to contact, addresses, telephone numbers, and office hours for each of these locations [Directory of Assistance Centers of the National Water Data Exchange (NAWDEX), U.S. Geological Survey Open-File Report 79-423 (revised)].

NAWDEX can assist any organization or individual in identifying and locating needed water data and referring the requester to the organization that retains the data required. To accomplish this service, NAWDEX maintains a computerized Master Water Data Index (fig. 9.2-2), which identifies sites for which water data are available, the type of data available for each site, and the organization retaining the data. A water Data Sources Directory (fig. 9.2-3) also is maintained that identifies organizations that are sources of water data and the locations within these organizations from which data may be obtained. In addition NAWDEX has direct access to some large water-data bases of its members and has reciprocal agreements for the exchange of services with others.

Charges for NAWDEX services are assessed at the option of the organization providing the requested data or data service. Search assistance services are provided free by NAWDEX to the greatest extent possible. Charges are assessed, however, for those requests requiring computer cost, extensive personnel time, duplicating services, or other costs encountered by NAWDEX in the course of providing services. In all cases, charges assessed by NAWDEX Assistance Centers will not exceed the direct costs incurred in responding to the data request. Estimates of cost are provided by NAWDEX upon request and in all cases where costs are anticipated to be substantial.

For additional information concerning the NAWDEX program or its services contact:

\author{
Program Office \\ National Water Data Exchange (NAWDEX) \\ U.S. Geological Survey \\ 421 National Center \\ 12201 Sunrise Valley Drive \\ Reston, VA 22092 \\ Telephone: (703) 860-6031 \\ FTS 928-6031
}

Hours: 7:45 - 4:15 Eastern Time

or

\author{
NAWDEX ASSISTANCE CENTER \\ KENTUCKY \\ U.S. Geological Survey \\ Water Resources Division \\ Room 572 - Federal Building \\ 600 Federal Place \\ Louisville, KY 40202
}

Telephone: (502) 582-5241

FTS 352-5241

Hours: 8:00 - 4:45 Eastern Time 


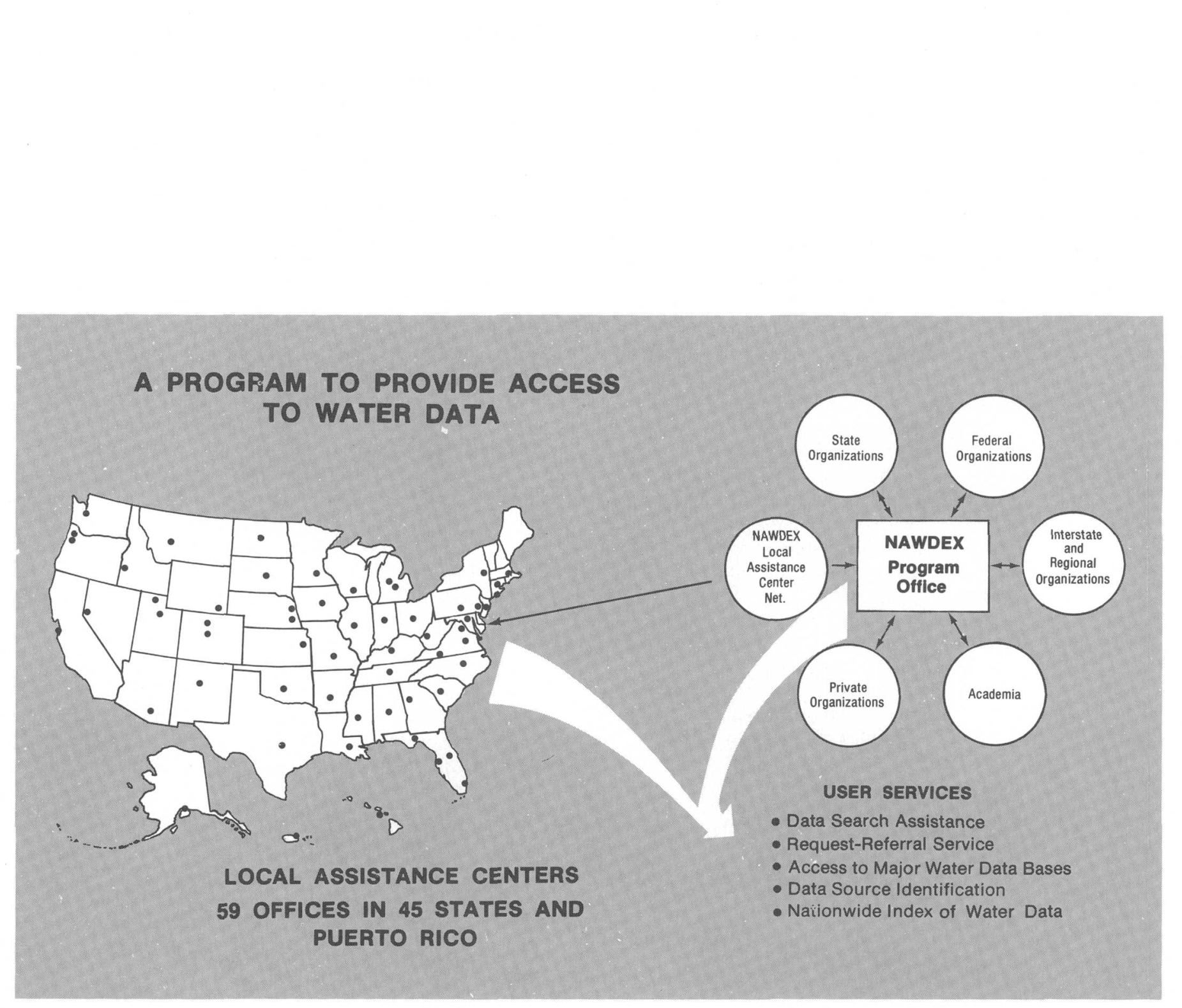

Figure 9.2-1 Access to water data.

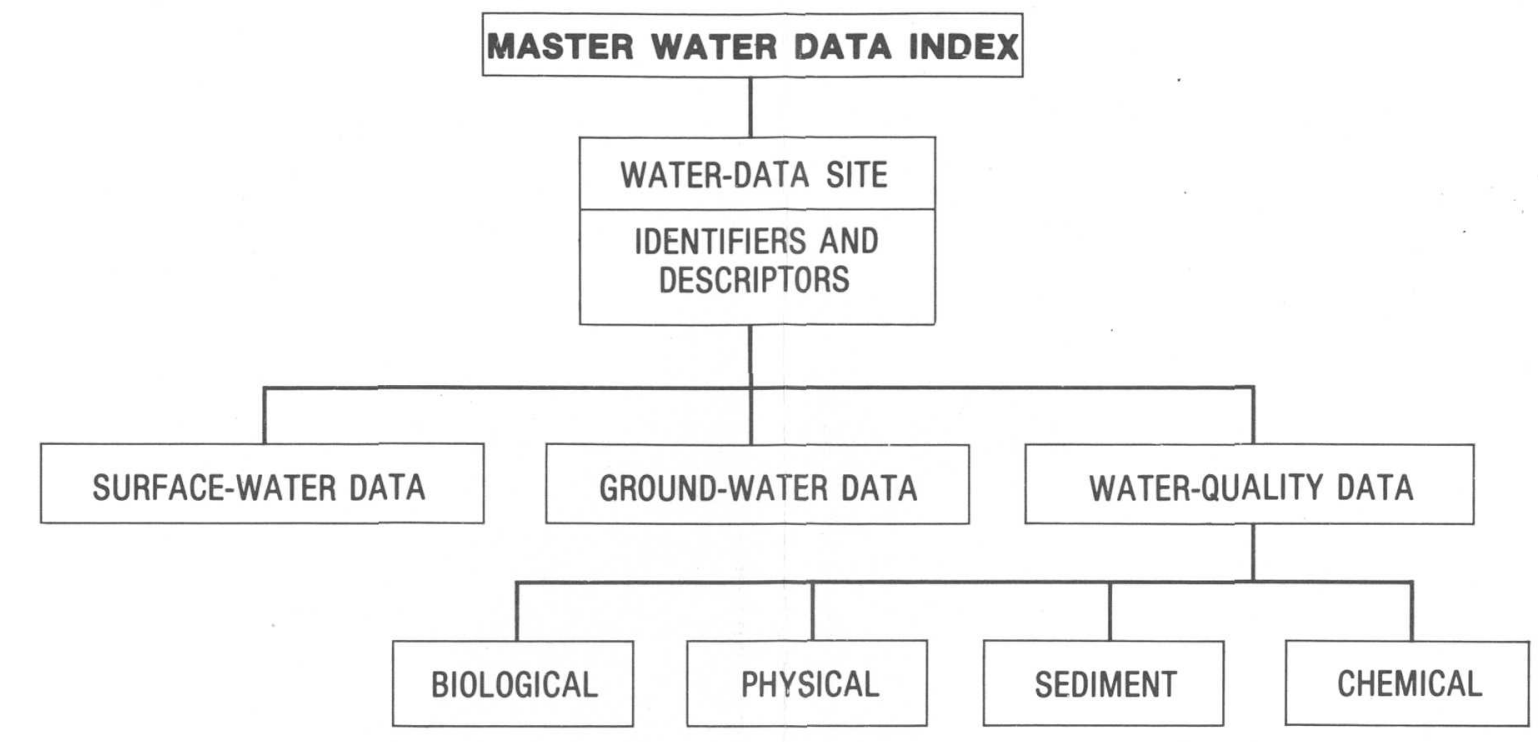

Figure 9.2-2 Master water-data index

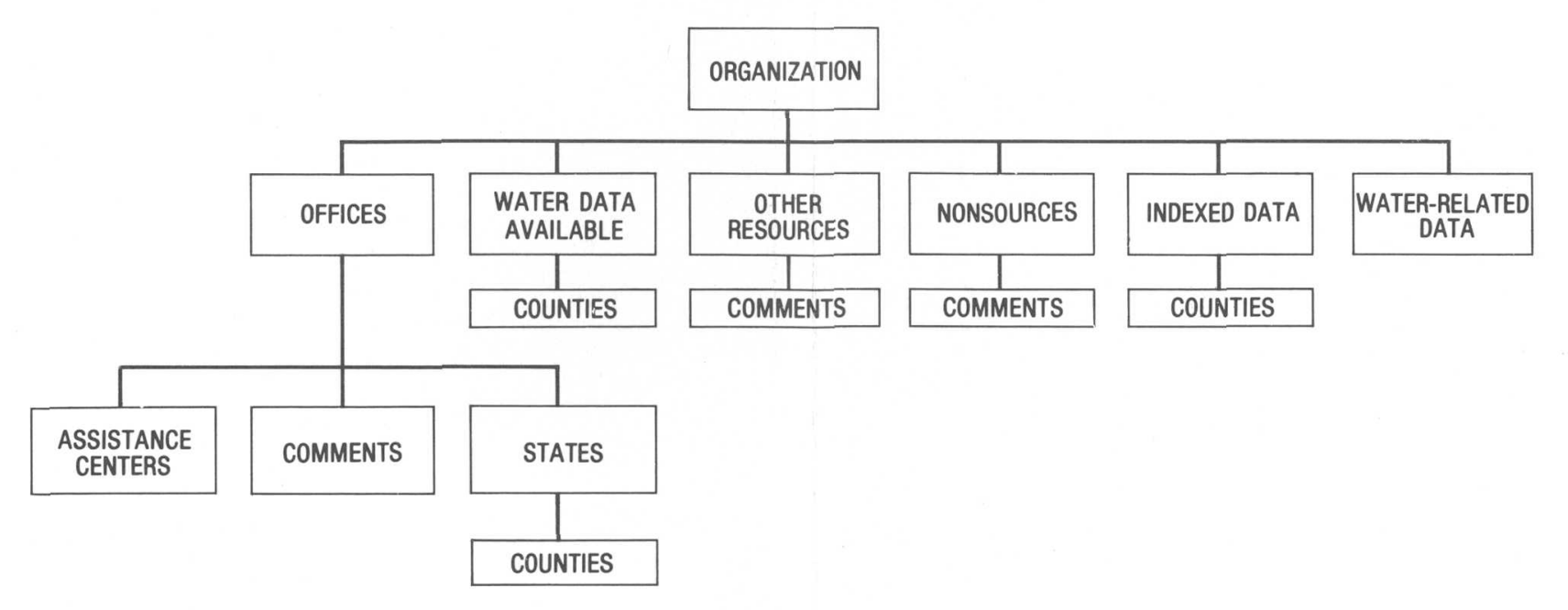

Figure 9.2-3 Water-data sources directory. 


\title{
9.0 WATER-DATA SOURCES--Continued 9.3 WATSTORE
}

\section{WATSTORE Automated Data System}

\author{
The National Water Data Storage and Retrieval System (WATSTORE) \\ of the U.S. Geological Survey provides computerized \\ procedures and techniques for processing water data \\ and provides effective and efficient management of \\ data-releasing activities.
}

\begin{abstract}
The National Water Data Storage and Retrieval System (WATSTORE) was established in November 1971 to computerize the U.S. Geological Survey's existing water-data system and to provide for more effective and efficient management of its data-releasing activities. The system is operated and maintained on the central computer facilities of the Survey at its National Center in Reston, Virginia. Data may be obtained from WATSTORE through the Water Resources Division's 46 district offices. General inquiries about WATSTORE may be directed to:
\end{abstract}

Chief Hydrologist

U.S. Geological Survey

437 National Center

Reston, VA 22092

or

U.S. Geological Survey
Water Resources Division
Room 572 - Federal Building
600 Federal Place
Louisville, KY 40202

The Geological Survey currently (1980) collects data at approximately 16,000 streamgaging stations, 1,000 lakes and reservoirs, 5,200 surface-water quality stations, 1,020 sediment stations, 30,000 waterlevel observation wells, and 12,500 ground-water quality wells. Each year many water-data collection sites are added and others are discontinued; thus, large amounts of diversified data, both current and historical, are amassed by the Survey's data-collection activities.

The WATSTORE system consists of several files in which data are grouped and stored by common characteristics and data-collection frequencies. The system is also designed to allow for the inclusion of additional data files as needed. Currently, files are maintained for the storage of: (1) surface-water, quality-of-water, and ground-water data measured on a daily or continuous basis; (2) annual peak values for streamflow stations; (3) chemical analyses for surface- and ground-water sites; (4) water parameters measured more frequently than daily; and (5) geologic and inventory data for ground-water sites. In addition, an index file of sites for which data are stored in the system is also maintained (fig. 9.3-1). A brief description of each file is as follows:

Station Header File: All sites for which data are stored in the Daily Values, Peak Flow, Water-Quality, and Unit Values files of WATSTORE are indexed in this file. It contains information pertinent to the identification, location, and physical description of nearly 220,000 sites.

Daily Values File: All water-data parameters measured or observed either on a daily or on a continuous basis and numerically reduced to daily values are stored in this file. Instantaneous measurements at fixed-time intervals, daily mean values, and statistics such as daily maximum and minimum values also may be stored. This file currently contains over 200 million daily values including data on streamflow, river stages, reservoir contents, water temperatures, specific-conductance, sediment concentrations, sediment discharges, and ground-water levels.

Peak Flow File: Annual maximum (peak) streamflow (discharge) and gage height (stage) values at surface-water sites comprise this file, which currently contains over 400,000 peak observations.

Water-Quality File: Results of over 1.4 million analyses of water samples that describe the chemical, physical, biological, and radiochemical characteristics of both surface and ground waters are contained in this file. These analyses contain data for 185 different constituents. 
Unit Values File: Water parameters measured on a schedule more frequent than daily are stored in this file. Rainfall, stream discharge, and temperature data are examples
Unit Values File.

Ground-Water Site-Inventory File: This file is discussed above, but it is cross-referenced to the contains inventory data about wells, springs, and other sources of ground water. The data included are site location and identification, geohydrologic characteristics, well-construction history, and onethe fiele is deasurements such as water temperature. ments and currently contains data for nearly 70,000 sites.

All data files of the WATSTORE system are maintained and managed on the central computer facilities of the Geological Survey at its National Center. However, data may be entered into or rethat are part of a nationwide telecommunication network.

Remote Job Entry Sites: Almost all of the Water Resources Division's district offices are equipped cess to the WATSTORE systemals for remote acallow each site to put data into or retrieve data from the system within several minutes to overnight, depending upon the priority placed on the request. The number of remote job entry sites is increased as the need arises.

Digital Transminission Sites: Digitai recorders are used at many field locations to record values for parameters such as river stages, conductivity, water temperature, turbidity, wind direction, and chlorides. Data are recorded on 16-channel paper tape, which is removed from the recorder and transmitted over telephone lines to the receiver at Reston, Viruse on the central computer. Extensive testing of satellite data collection platforms indicates their feasibility for collecting real-time hydrologic data on a national scale. Battery-operated radios are used as the communication link to the salellie. About 200 data relay stations are being operated currently

Central Laboratory System: The Water Resources Division's two water-quality laboratories, analyze more than 150,000 water samples per year. perform chemical analyses ranging from determina- tions of simple inorganic compounds, such as chloides, to complex organic compounds, such as pestiides. As each analysis is completed, the results are verifed by laboratory personnel and transmitted via computer terminal to the central computer facilities

Water data are used in many ways by decisionmakers for the management, development, an monitoring of our water resources. In addition to its data processing, storage, and retrieval capabilites, WATSTORE can provide a variety of usefu products ranging from computer cost incurred in producing a desired product, is charged to the requester.

Computer-Printed Tables: Users most often request data from WATSTORE in the form of tables printed by the computer. These tables may contain the availability of dable stored in the files. A variety of formats is available to display the many types of

Computer-Printed Graphs: Computer-printed graphs for the rapid analysis or display of data are are (histograms), line graphs, frequency distribution curves, $X-Y$ point plots, site-location map plots, and other similar items by means of line printers.

Statistical Analyses: WATSTORE interfaces with a proprietary statistical package (SAS) to providh a prepre analyses of data such as regression and correlations.

Digital Plotting: WATSTORE also makes use of software systems that prepare data for digital plo ting on peripheral offline ploters available at the include hydrographs, frequency distribution curves, $X-Y$ point plots, contour plots, and three-dimensional plots.

Data in Machine-Readable Form: Data stored in WATSTORE can be obtained in machine-readable form for use on other computers or for use as input available in the standard storage format of th WATSTORE system or in the form of punched cards or card images on magnetic tape.

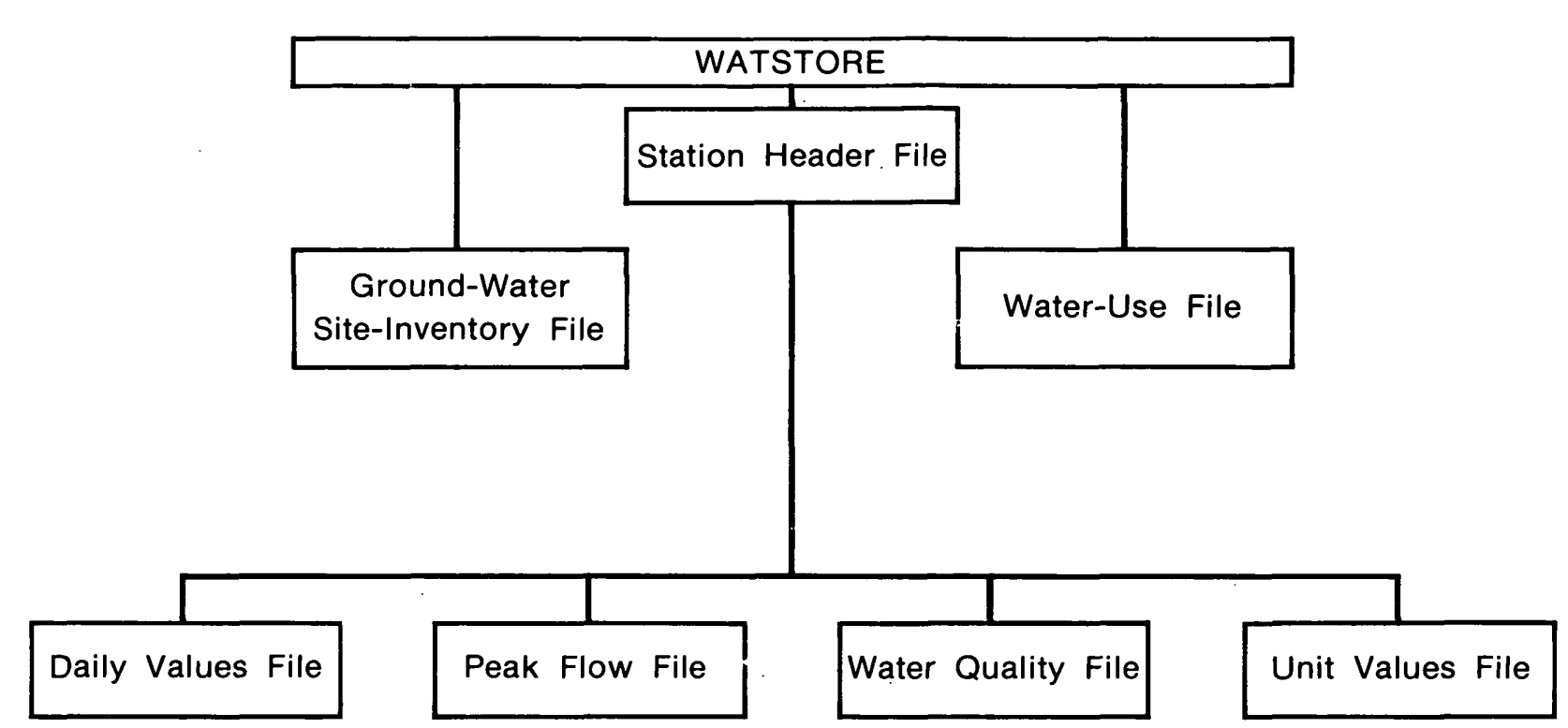

Figure 9.3-1 Index file stored data 


\author{
9.0 WATER-DATA SOURCES--Continued \\ 9.4 Index to Water-Data Activities in Coal Provinces
}

\title{
Water Data Indexed for Coal Provinces
}

\section{A special index, "Index to Water-Data Activities in Coal Provinces of the United States," has been published by the U.S. Geological Survey's Office of Water Data Coordination (OWDC).}

The "Index to Water-Data Activities in Coal Provinces of the United States" was prepared to assist those involved in developing, managing, and regulating the Nation's coal resources by providing information on the availability of water-resources data in the major coal provinces of the United States. It is derived from the "Catalog of Information on Water Data," which is a computerized information file about water-data acquisition activities in the United States, and its territories and possessions, with some international activities included.

This special index consists of five volumes (fig. 9.4-1): volume I, Eastern Coal province; volume II, Interior Coal province; volume III, Northern Great Plains and Rocky Mountain Coal provinces; volume IV, Gulf Coast Coal province; and volume V, Pacific Coast and Alaska Coal provinces. The information presented will aid the user in obtaining data for evaluating the effects of coal mining on water resources and in developing plans for meeting additional water-data needs. The report does not contain the actual data; rather, it provides information that will enable the user to determine if needed data are available.

Each volume of this special index consists of four parts: Part A, Streamflow and Stage Stations; Part B, Quality of Surface-Water Stations; Part C, Quality of Ground-Water Stations; and Part D, Areal Investigations and Miscellaneous Activities. Information given for each activity in Parts A-C includes: (1) the identification and location of the station, (2) the major types of data collected, (3) the frequency of data collection, (4) the form in which the data are stored, and (5) the agency or organization reporting the activity. Part D summarizes areal hydrologic investigations and water-data activities not included in the other parts of the index. The agencies that submitted the information, agency codes, and the number of activities reported by type are shown in a table.

Those who need additional information from the Catalog file or who need assistance in obtaining water data should contact the National Water Data Exchange (NAWDEX) (see section 9.2).

Further information on the index volumes and their availability may be obtained from:

\author{
U.S. Geological Survey \\ Water Resources Division \\ Room 572 - Federal Building \\ 600 Federal Place \\ Louisville, KY 40202 \\ Telephone: (502) 582-5241 \\ FTS 352-5241
}

or

Office of Surface Mining

U.S. Department of the Interior 530 Gay St., Suite 500 Knoxville, TN 37902

Telephone: (615) 637-8060

FTS $852-0060$ 


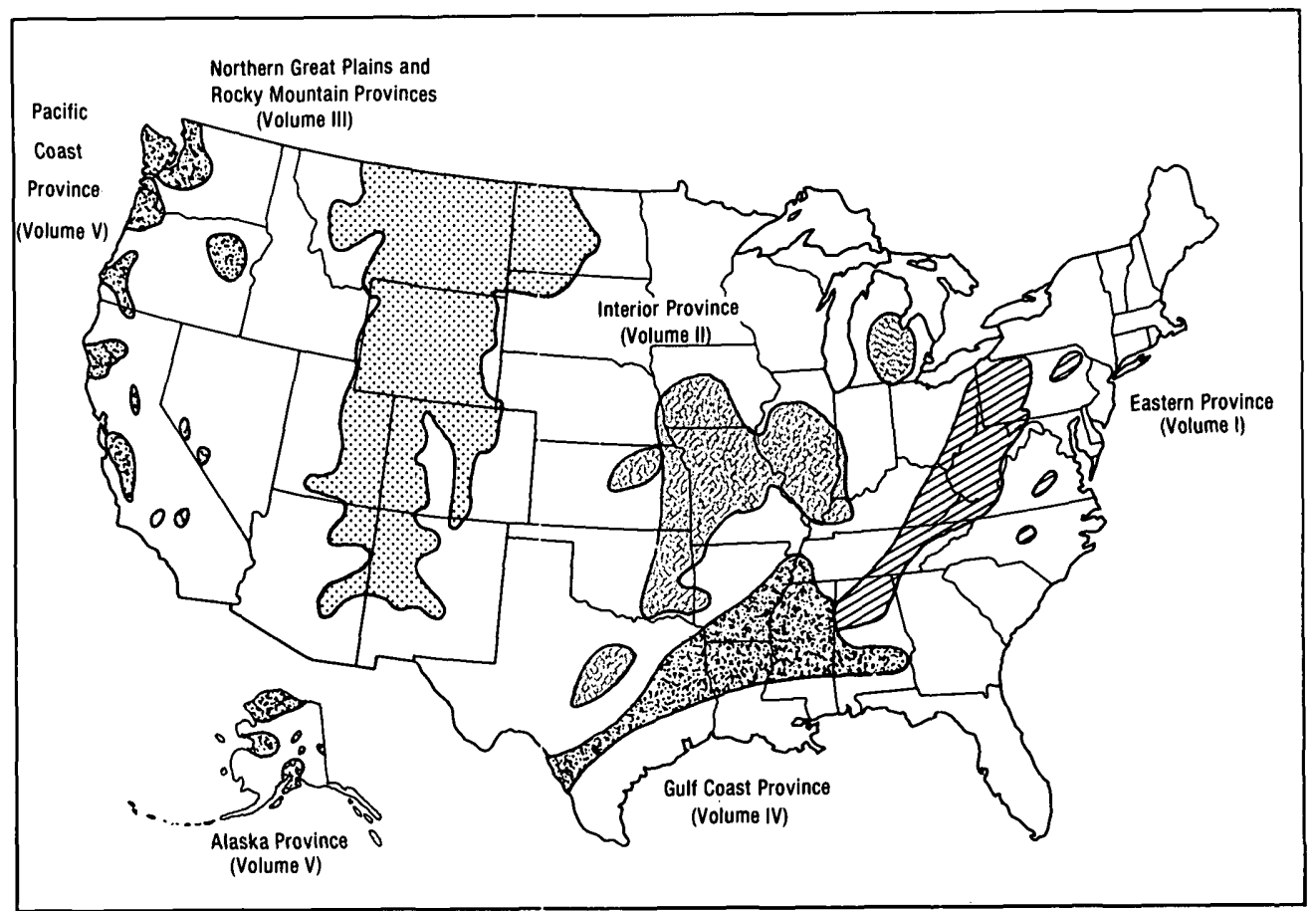

Figure 9.4-1 Index volumes and related provinces. 


\subsection{SUPPLEMENTAL INFORMATION FOR AREA 15}

10.1 Index of Geologic Quadrangle Maps

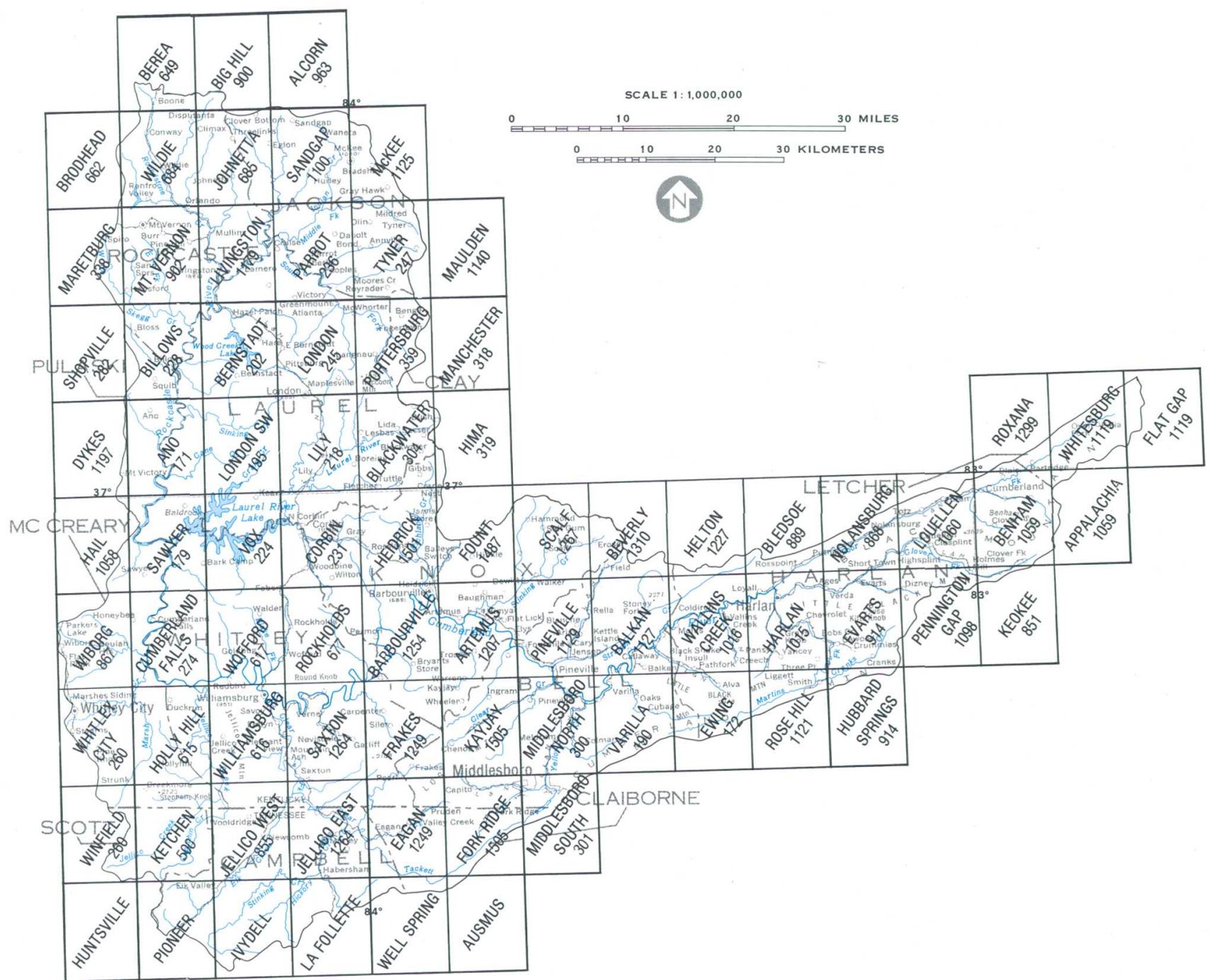

BASE FROM U. S. GEOLOGICAL SURVEY
STATE BASE MAP, 1973

AGENTS FOR MAP SALES

Kentucky Geological Survey

311 Breckinridge Hall

University of Kentucky

Lexington, KY 40506

Kentucky Department of Commerce

Map Sales Office

133 Holmes Street

Frankfort, KY 40601

U.S. Geological Survey

Branch of Distribution

1200 South Eads Street

Arlington, VA 22202 
50103400480 Looney Creek near Clutts, Ky

50203400500 Poor Fork at Cumberland, Ky

50303400585 Poor Fork at Rosspoint, Ky

50403400650 Clover Fork near Shields, Ky

50503400700 Clover Fork at Evarts, Ky

50603400735 Martins Fork near Middlesboro,Ky

50703400796 Crane Creek near Smith, Ky

50803400798 Martins Fork Lake near Smith,Ky

50903400800 Martins Fork near Smith,Ky

51003400985 Martins Fork at Harlan, Ky

51103400990 Clover Fork at Harlan, Ky

51203401000 Cumberland River near Harlan,Ky

51303401040 Pearl Branch at Wallins Creek, Ky

51403401250 Puckett Creek near Pathfork, Ky

51503401290 Brownice Creek near Oaks,Ky

51603401400 Left Yellow Creek at Middlesboro,Ky

51703401406 Yellow Creek at Middlesboro,Ky (upstream from sewage treatment plant)

51803401407 Yellow Creek at Middlesboro,Ky

51903401430 Bennetts Fork near Middlesboro,Ky

52003401500 Yellow Creek Bypass Middlesboro, Ky

52103402000 Yellow Creek near Middlesboro,Ky

52203402010 Shilalah Creek near Middlesboro,Ky

52303402230 Yellow Creek near Ferndale,Ky

$52403402400 \quad$ Clear Creek near Pineville, Ky

52503402450 Little Clear Creek near Pineville,Ky

52603402480 Clear Creek at Clear Creek Springs, K.y

52703402490 Straight Creek at Pineville,Ky

52803402500 Cumberland River at Pineville, Ky

52903402800 Straight Creek near Kettle Island,Ky

53003402830 Left Fork Straight Creek near Cary, Ky

53103402850 Left Fork Straight Creek at Cary,Ky

53203402852 Straight Creek at Straight Creek,Ky

53303402990 Cumberland River below Pineville,ky

53403403000 Cumberland River near Pineville,Ky

53503403100 Middle Fork Stinking Creek near Walker, Ky

53603403150 Road Fork Creek near Barnyard,Ky

53703403180 Stinking Creek at Dewitt,Ky

53803403255 Road Fork at Dewitt,Ky

53903403500 Cumberland River at Barbourville,Ky

54003403530 Richland Creek near Barbourville,Ky

54103403538 Little Richland Creek near Hinkle, Ky

54203403550 Little Indian Creek near Permon, Ky

54303403590 Fourmile Branch near Bryants Store,Ky

54403403697 Clear Fork at Highway 90 at Anthras, Tn

54503403710 Tackett Creek at Anthras, Tn

54603403715 Stinking Creek near Newcomb, Tn

54703403720 Lick Creek at Haversham, $\mathrm{Tn}$

54803403740 Hickory Creek at Morley, Tn

548A 03403750 Clear Creek near Jellico, Tn

54903403770 E1m Creek at Newcomb, Tn

549A 03403800 E1k Creek at Jellico,Tn

55003403900 Clear Fork at Sukey Siler Hollow,

Saxton, Ky
$51.7 \quad 370000 \quad 0825435 \quad$ NO

- $\quad 3658170825806$ NO

$82.3 \quad 3658260825935 \quad$ YES

$142 \quad 3653040831719 \quad$ NO

- 3653480830825 No

$82.4 \quad 3651560831137$ NO

- $\quad 3640500832753$ No

1.633644510831550 No

$55.7 \quad 3645080831531$ YES

$55.8 \quad 3644570831452 \quad$ YES

$116 \quad 3649570831936 \quad$ NO

$222 \quad 3650500831931$ No

$374 \quad 3650480832121 \quad$ YES

$1.4 \quad 3650070832443 \quad$ No

- 3645190832745 No

- 3643180833332 NO

$10.8 \quad 3636300834213 \quad$ NO

- 3637270834233 No

- 3637390834227 No

- 3636240834447 NO

$35.3 \quad 3637520834345 \quad$ NO

60.63640050834119 YES

- 3638570833419 NO

$99.5 \quad 3642350833840 \quad$ NO

- 3643420834429 NO

- 3643170834327 NO

- $\quad 3643400834842$ NO

- $\quad 3645570834123$ No

676

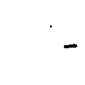

3647060833609

- 3647540833936 NO

$33.7 \quad 3647290833057$ No

$89.8 \quad 3646240834012$ NO

$806 \quad 3647490834539$ NO

$809 \quad 3648480834558 \quad$ YES

$3653140834225 \quad$ NO

$3654020834441 \quad$ NO

$49.1 \quad 3652350834417 \quad$ NO

$25.2 \quad 3652380834417$ NO

$960 \quad 3651450835313 \quad$ YES

$27.7-0835420 \quad$ NO

$11.6 \quad 3655490834954$ NO

- $\quad 3649400835821$ NO

- 3646480835605 NO

- 3632460835936 NO

- 3632250840020 NO

- 3630260840836 No

- 3630010840432 No

- 3633000840242 NO

$240 \quad 3635130840516$ NO

- $3633100840953 \quad N 0$

51.13634590840821 NO

- $\quad 3637300840638$ NO

$\begin{array}{rrrrr}1940 & 1943 & - & - & \text { NO } \\ 1979 & - & 1979 & - & \text { YES } \\ 1940 & - & 1979 & - & \text { YES } \\ 1972 & 1977 & - & - & \text { NO } \\ 1979 & - & 1979 & - & \text { YES } \\ 1954 & - & 1960 & 1972 & \text { NO } \\ 1979 & 1979 & 1979 & 1979 & \text { YES } \\ 1976 & 1977 & - & - & \text { NO } \\ 1979 & - & 1979 & - & \text { NO } \\ 1971 & - & 1970 & - & \text { YES } \\ 1960 & 1960 & - & - & \text { NO } \\ 1978 & - & 1978 & - & \text { YES } \\ 1940 & - & 1949 & - & \text { YES } \\ 1976 & - & - & - & \text { NO } \\ 1979 & - & 1979 & - & \text { YES } \\ 1979 & - & 1979 & - & \text { YES } \\ 1959 & 1966 & 1964 & 1965 & \text { NO } \\ - & - & 1965 & 1965 & \text { NO }\end{array}$

No

No

No

No

YES

YES

No

YES

YES

No

No

No

YES

YES

No

No

No

YES

YES

YES

No

No

YES

No

NO

YES

YES

YES

YES

YES

YES

YES

No

YES

No

No

YES 


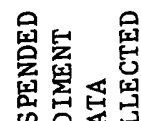

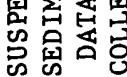

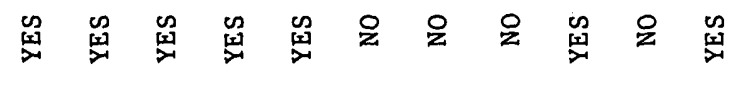

울

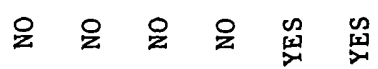

\&

密典罢

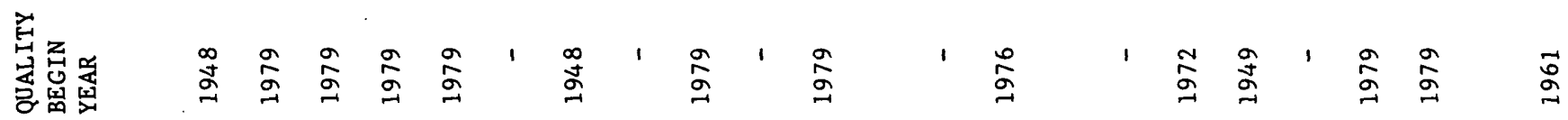

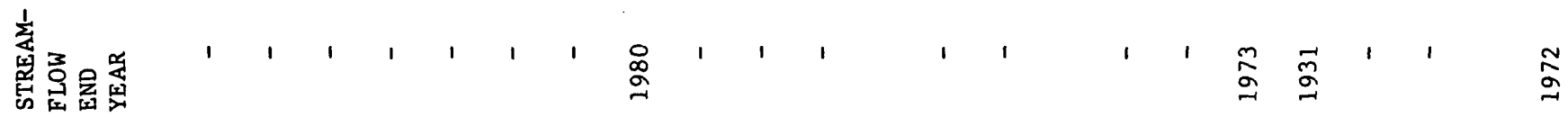

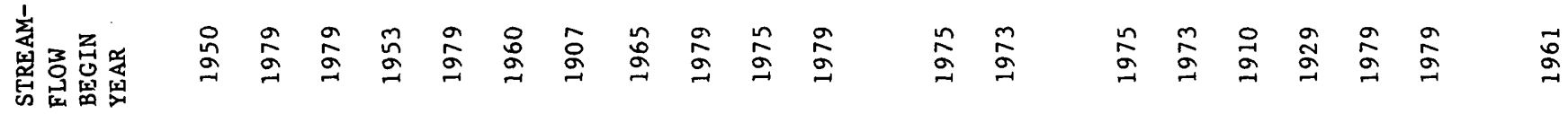

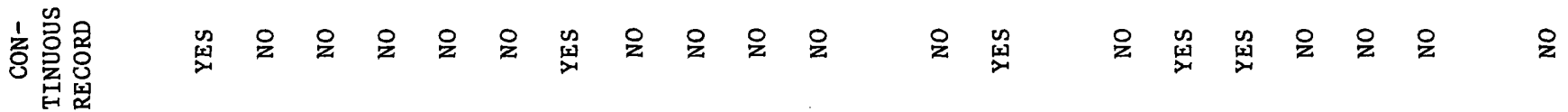

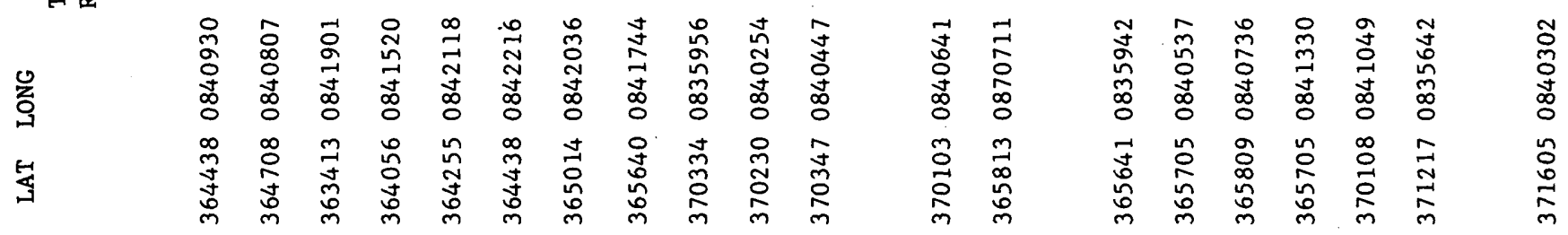

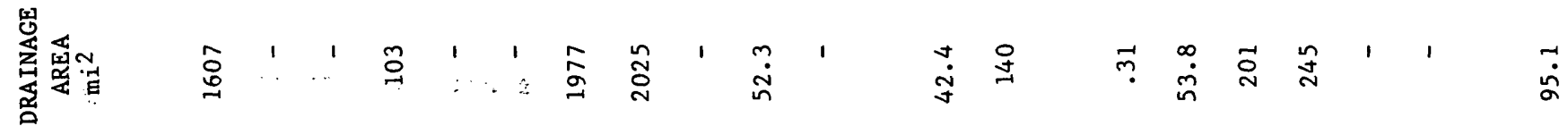

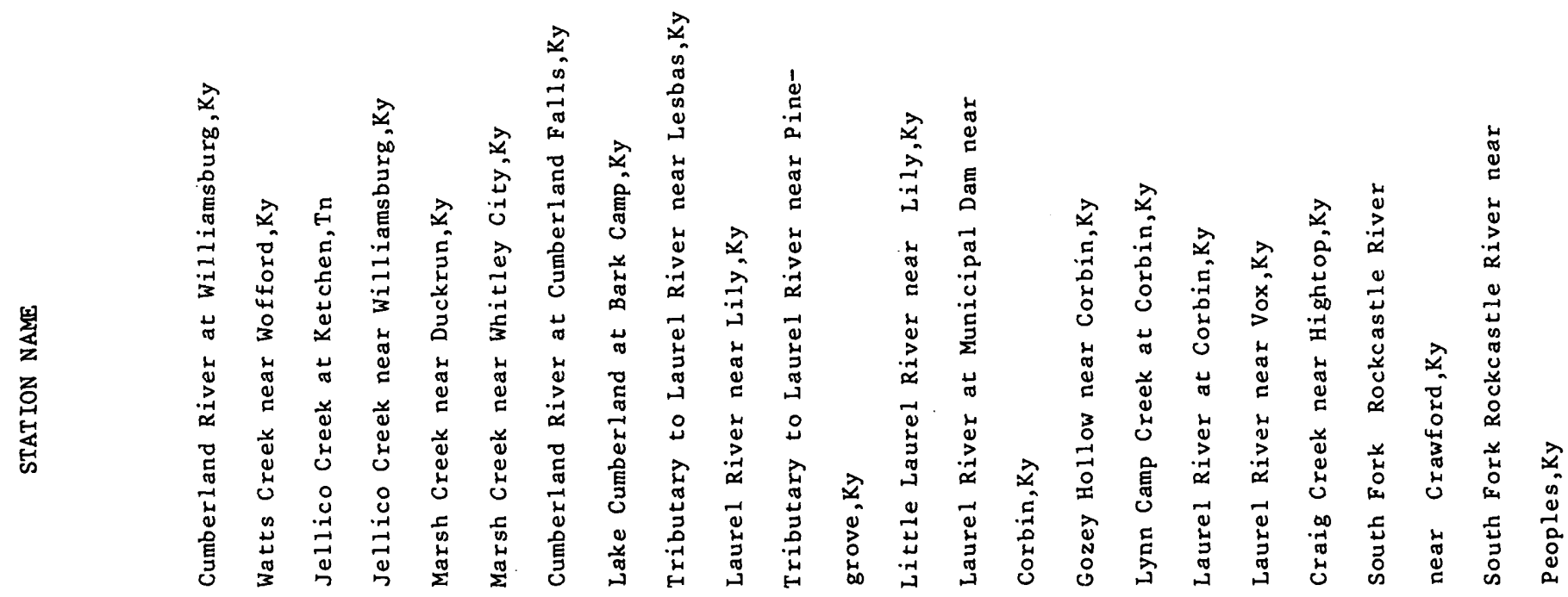

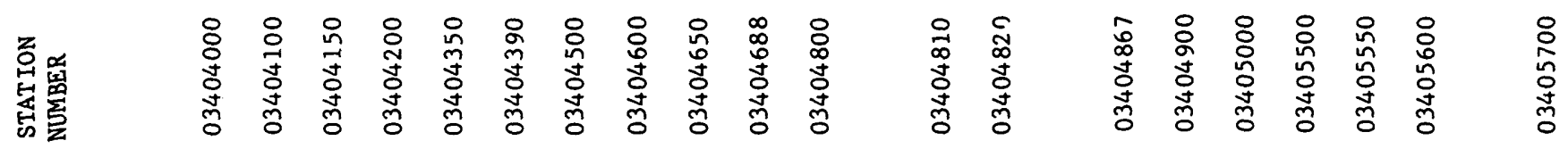

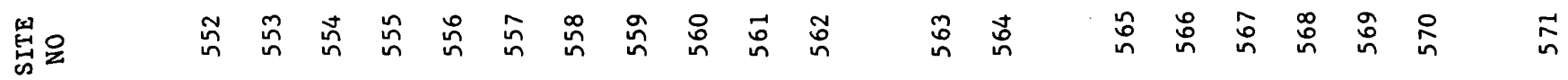


$\frac{1}{2}$

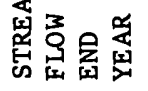

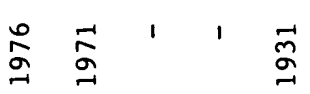

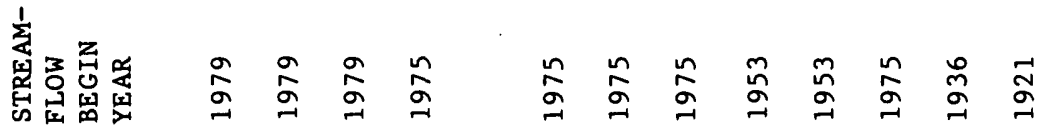

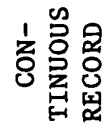

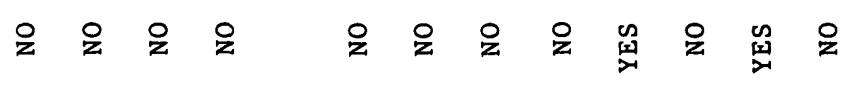

萬

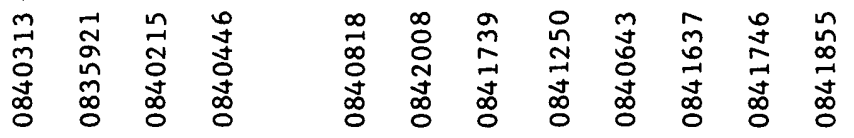

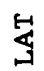

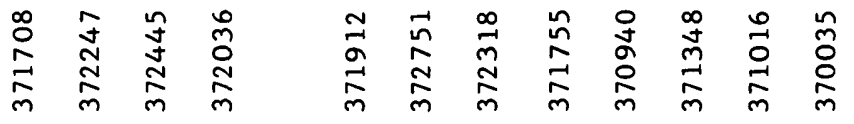

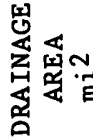

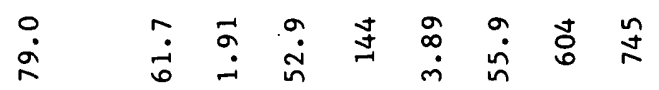

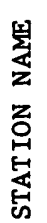

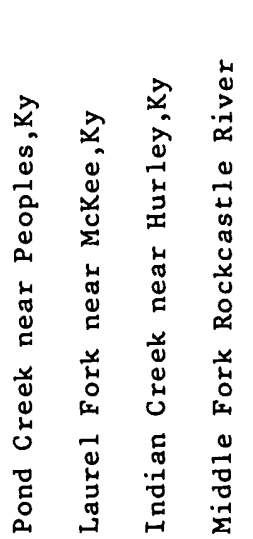

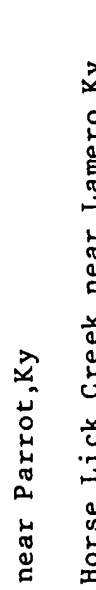

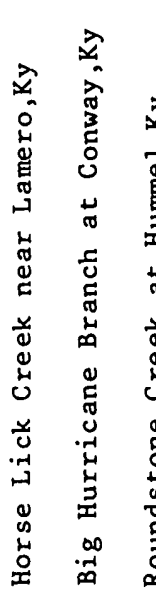

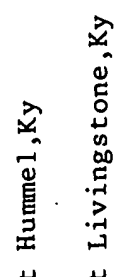

政

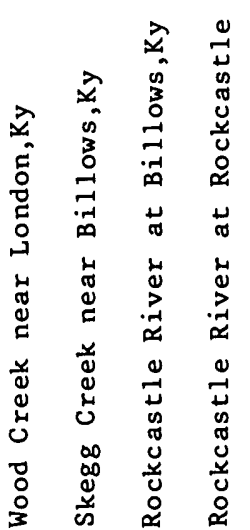

忌品

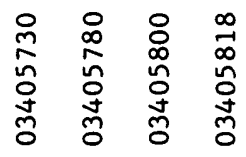

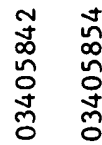

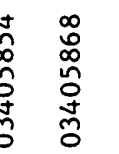

:

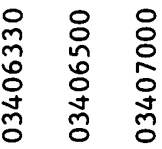

点是

汸点

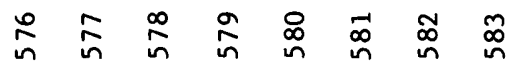




\subsection{SUPPLEMENTAL INFORMATION FOR AREA 15}

10.3 Ground-Water Network

$\sum_{i=1}^{0} \frac{\alpha}{\alpha}$

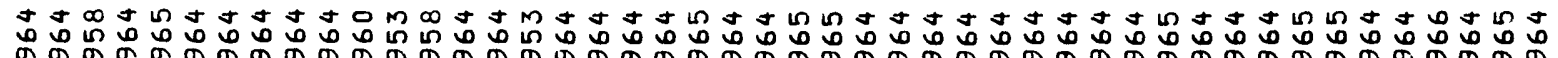

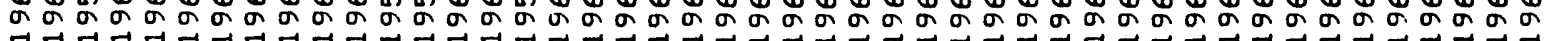
$\sum_{\substack{m \\ 0}}^{\infty} \frac{\alpha}{2}$

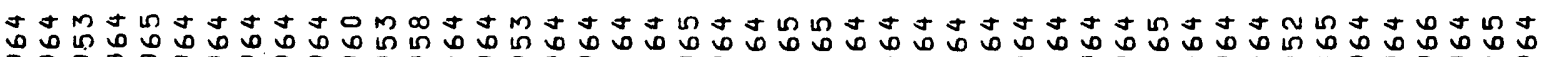

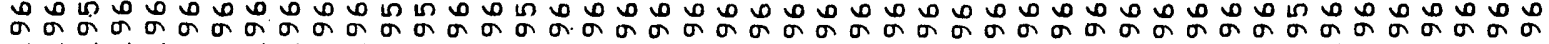

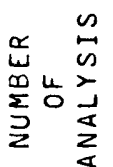

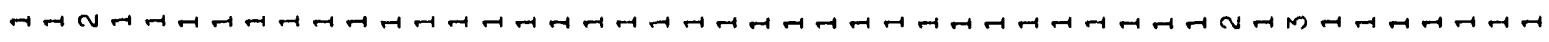

I

000000

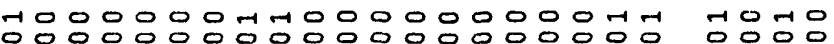

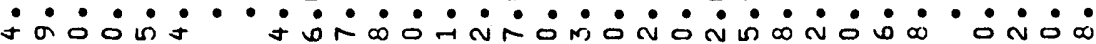

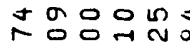

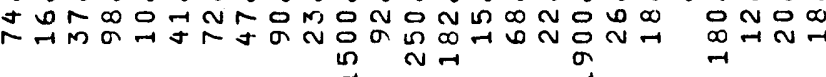

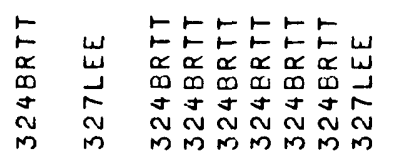

トレトトたトたト

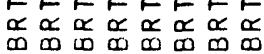

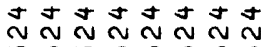

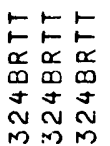

トレトルミ

た5

品品品政品

$a t a t$

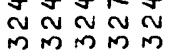

in

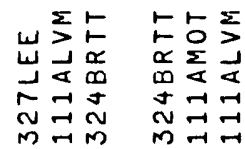

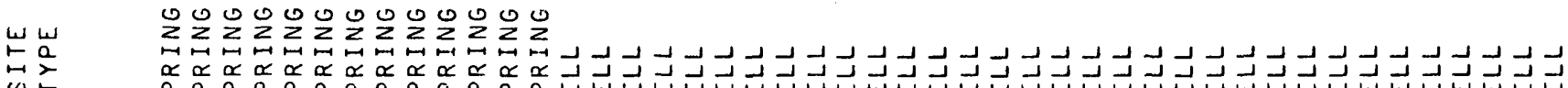

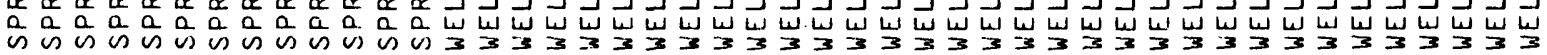
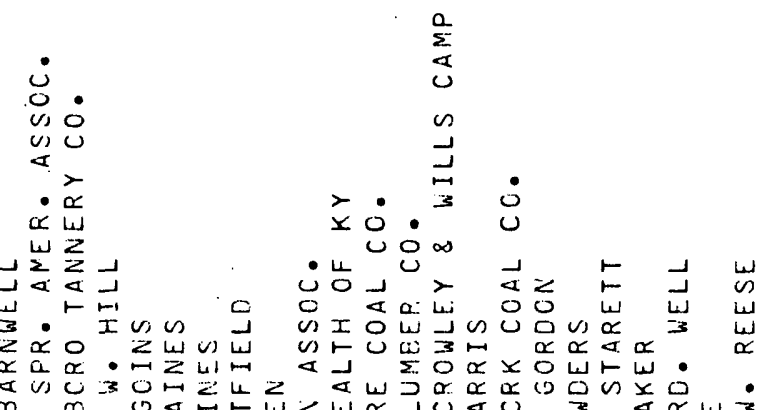

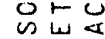

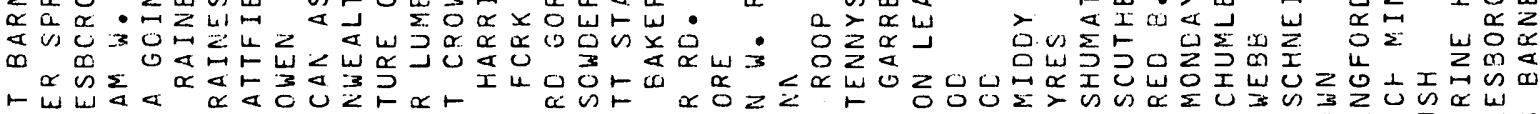

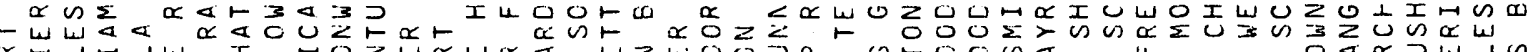

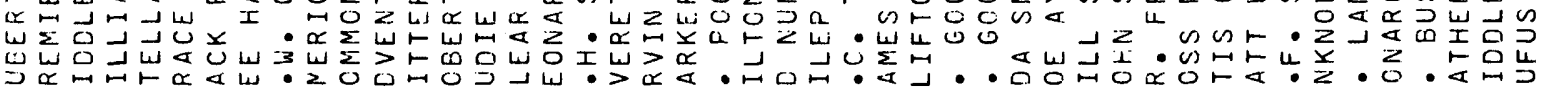

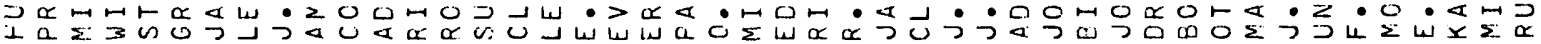

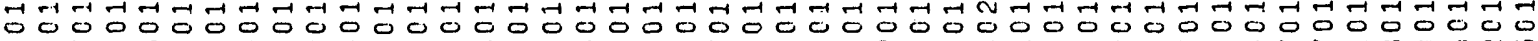

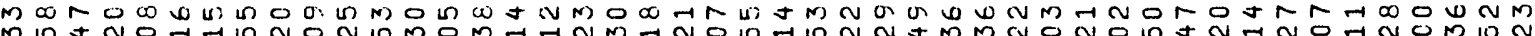
m

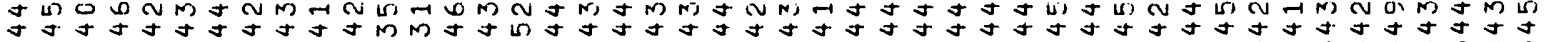

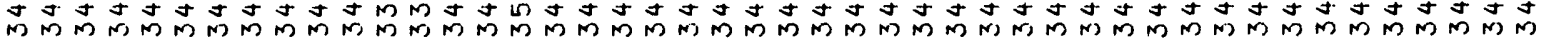

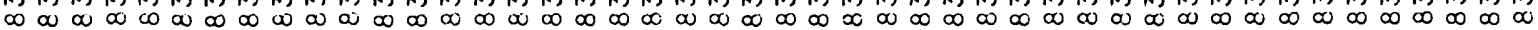

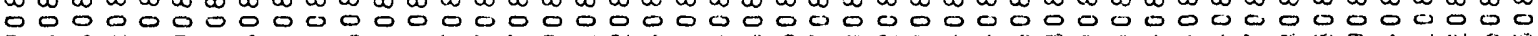

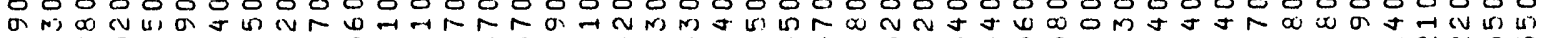

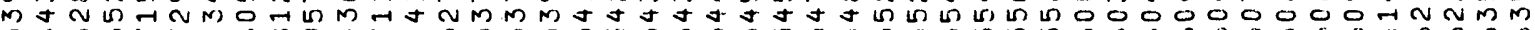
组

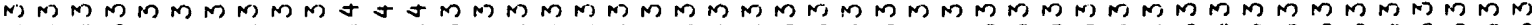

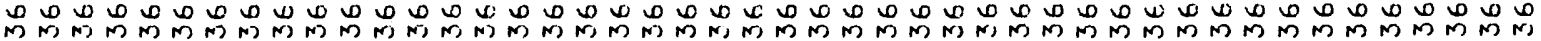



UNIT OF
WELL ANALYSIS

363638083412301 V.R. -UCHNSON 363638083481301 MITE WARD

363639083424801 CITY CF MIOCLESEORO, KY $3636430834508 C 1$ EDGAR TAYLOR

363644083451701 GOROCN TURNER

363645083452301 ROBERT SMITH

363646083435101 UNKNOWIN

363646083465701 BELL CCUNTY SCHOCLS

363646083470501 EUD SWIANNICON

$36364 E 083472301$ UNKNCWA

363649083461701 QUILL VANCVER

363649083495701 UNION SCHCOL

$\begin{array}{ll}363650083453901 & \text { C.B. JOHNSON } \\ 363651083453701 & \text { LUTHER SULFREOG }\end{array}$

363651083495001 GARNECA

363652083463901 J.M. HUBER CORP.

363654083474401 NARY BURTON

363655083412501 K. STEPHENSON

363658083422601 PERMA PIPE CO.

363702083452501 CLAIR HUNLEY

363714083435001 WALTER FARMER

363714083454201 CECIL FRY

363715083421301 . MAYNARD GOINS

363718083421301 OSCAR B. MIRACLE

363719083451501 HUGH GORDON

363722083421301 CTTC GUILLEN

363724083453601 GILRERT MARTIN

363725083451101 EARL OVEFTON

363726083434501 MIRL COLLINGSWCRTH

363727083435101 ALEXANDER OSEORNE

363730083423501 MID. TANNERY

363731083420501 EILL EROCKS

363734083431501 KENNETH ELLISON

363734083452401 JUNIOR GOROON

363735083440701 ECB PAVIS

363736083432001 MCSE GCDSEY

363743083434801 ZANE RAINES

36373083434801

36375208342150

363753083435501

363800083421301

36380108342540

363802083424401

363803083451601

36380408342230

36380808342190

36380908343330

36381008340100

36381808341580

363819083422401

36381083422401

363824083424201

363825083421101

363825083421101

36383008342110

36383108342090

363833083422001

363833083422001

363840083420001
363840083442101

364005083322501

36401008331150

364012083311001

364024083410301
364234083383801

364234083383801
364326083383101

364326083383101
364420083441901

364420083441901
364425083445501

364435083422701

36452308341350

364545083422601
364547083422601

364547083422601
364619083461601

364619083461601
364723083443001

36472508344330

36480408330340

IS. BANGO

IM HARVILLE

CEXTER DILLMAN

SHARFS COURT

INNIE L. JOHNSON

MS. RUTH MELTON:

M. V. VANEEUER

RCY JANEWAY
RED MAXWELL

OB CCRPS

DWARE MC GEORGE

CKINLEY SNITH

AMON HELTCN

RANCIS HELTON

CAL SMITH

IGHWAY OIL CO.

-REDMAN

ILLETT HAROWOOD, CO.

-W. KOONTS

CAN ASSOC.

HENSLEY FLATS TW NO.2

JCE CCRPS

HENSLEY FLATS TW NO.

J.L. ROBINS

TVA FINEVILLE, KY

COMMONWEALTH OF KY

COMNONWEALTH OF KY

COMMONWEALTH OF KY

PINEVILLE. WATER CO.
PINEVILLE HOSPITAL

PINEVILLE HOSPITAL

MS. ETHYLE TINSLEY
LCNE JACK COMNUNITY

LCNE JACK COMNUNITY
BELL CO. BD OF ED.

BELL CO. BD OF ED
KY CARCINAL CO.

\begin{tabular}{|c|c|c|c|c|c|}
\hline WELL & $324 \mathrm{BRTT}$ & 63.00 & 1 & 1965 & 1965 \\
\hline WELL & & 22.00 & 1 & 1964 & 1964 \\
\hline WELL & & 1600.00 & 1 & 1964 & 1964 \\
\hline WELL & $111 \mathrm{AMOT}$ & 14.00 & 1 & 1964 & 1964 \\
\hline WELL & & 53.00 & 1 & 1964 & 1964 \\
\hline WELL & $111 \mathrm{AMOT}$ & 15.00 & 1 & 1964 & 1964 \\
\hline WELL & $111 \mathrm{ALVM}$ & 15.01 & 1 & 1965 & 1965 \\
\hline WELL & $324 \mathrm{BRTT}$ & 71.00 & 1 & 1964 & 1964. \\
\hline WELL & & 23.00 & 1 & 1964 & 1964 \\
\hline WELL & & 38.00 & 1 & 1964 & 1964 \\
\hline WELL & & - & 1 & 1964 & 1964 \\
\hline WELL & $324 B R T T$ & 94.00 & 1 & 1965 & 1965 \\
\hline WELL & 111AMOT & 11.00 & 1 & 1964 & 1964 \\
\hline WELL & & 23.00 & 1 & 1964 & 1964 \\
\hline WELL & $324 B R T T$ & 125.00 & 1 & 1964 & 1964 \\
\hline WELL & & 36.00 & 1 & 1964 & 1964 \\
\hline WELL & & 18.00 & 1 & 1964 & 1964 \\
\hline WELL & $324 \mathrm{BRTT}$ & • & 1 & 1964 & 1964 \\
\hline WELL & $324 \mathrm{BRTT}$ & 190.00 & 1 & 1961 & 1961 \\
\hline WELL & & 20.00 & 1 & 1964 & 1964 \\
\hline WELL & $324 B R T T$ & 36.00 & 2 & 1964 & 1964 \\
\hline WELL & & 55.00 & 1 & 1964 & 1964 \\
\hline WELL & & 44.00 & 1 & 1964 & 1964 \\
\hline WELL & $324 \mathrm{BRTT}$ & 65.00 & 1 & 1965 & 1965 \\
\hline WELL & 324 BRTT & 22.00 & 1 & 1965 & 1965 \\
\hline WELL & & 41.00 & 1 & 1964 & 1964 \\
\hline WELL & $324 \mathrm{BRTT}$ & 50.00 & 1 & 1965 & 1965 \\
\hline WELL & & 14.00 & 1 & 1964 & 1964 \\
\hline WELL & & 14.00 & 1 & 1964 & 1964 \\
\hline WELL & $324 \mathrm{BRTT}$ & 60.00 & 1 & 1964 & 1964 \\
\hline WELL & $324 B R T T$ & 230.00 & 1 & 1964 & 1964 \\
\hline $\begin{array}{l}\text { WELL } \\
\text { WELL }\end{array}$ & 327 LEE & $\begin{array}{r}940.00 \\
27.00\end{array}$ & $\begin{array}{r}16 \\
1\end{array}$ & $\begin{array}{l}1964 \\
1965\end{array}$ & $\begin{array}{l}1980 \\
1965\end{array}$ \\
\hline WELL & & 134.00 & 1 & 1964 & $\begin{array}{l}1965 \\
1964\end{array}$ \\
\hline WELL & & 27.00 & 1 & 1964 & 1964 \\
\hline$W^{\prime} E L L$ & 324 BRTT & 58.00 & 1 & 1964 & 1964 \\
\hline WELL & $324 \mathrm{ERTT}$ & 68.00 & 1 & 1964 & 1964 \\
\hline WELL & $324 E R T T$ & 42.00 & 1 & 1964 & 1964 \\
\hline WELL & 32.4 BRTT & 25.00 & 1 & 1964 & 1964 \\
\hline WELL & $324 \mathrm{BRTT}$ & 287.00 & 1 & 1964 & 1964 \\
\hline WELL & 324 ERTT & 64.00 & 1 & 1964 & 1964 \\
\hline WELL & $324 \mathrm{BRTT}$ & 124.00 & 1 & 1964 & 1964 \\
\hline WELL & 324 ERTT & 133.00 & 1 & 1964 & 1964 \\
\hline WELL & $324 B R T T$ & 96.00 & 2 & 1964 & 1964 \\
\hline WELL & & 83.00 & 1 & 1964 & 1964 \\
\hline WELL & & 29.00 & 1 & 1964 & 1964 \\
\hline WELL & $324 B R T T$ & 15.00 & 1 & 1964 & 1964 \\
\hline WELL & $324 \mathrm{ERTT}$ & 109.00 & 1 & 1964 & 1964 \\
\hline WELL & $324 \mathrm{ERTT}$ & 14.00 & 1 & 1964 & 1964 \\
\hline WELL & $327 \mathrm{LEE}$ & 450.00 & 1 & 1967 & 1967 \\
\hline WELL & 324BRTT & 137.00 & 2 & 1964 & 1964 \\
\hline WELL & $324 B R T T$ & $65 \cdot C 0$ & 1 & 1964 & 1964 \\
\hline WELL & 3. $45 . \mathrm{TT}$ & 39.00 & 1 & 1964 & 1964 \\
\hline WELL & 324 ERTT & 10.00 & 1 & 1964 & 1964 \\
\hline WELL & $024 \forall K I T$ & 9.00 & 1 & 1964 & 1964 \\
\hline WELL & 324 ERTT & 87.00 & 1 & 1964 & 1964 \\
\hline WELL & $324 E R T T$ & 96.00 & 1 & 1964 & 1964 \\
\hline WELL & $324 \mathrm{BRTT}$ & 85.00 & 1 & 1964 & 1964 \\
\hline WELL & $324 B R T T$ & 90.01 & 2 & 1964 & 1965 \\
\hline WELL & $324 E R T T$ & - & 1 & 1964 & 1964 \\
\hline WELL & $324 B R T T$ & 130.00 & 1 & 1964 & 1964 \\
\hline WELL & $3248 R T T$ & 106.00 & 1 & 1964 & 1964 \\
\hline WELL & 327 LEE & 1500.00 & 1 & 1964 & 1964 \\
\hline WELL & & - & 1 & 1974 & 1974 \\
\hline WELL & 327 LEE & 450.00 & 5 & 1967 & 1975 \\
\hline WELL & & - & 1 & 1974 & 1974 \\
\hline WELL & $324 \mathrm{BRTT}$ & 111.00 & 1 & 1964 & 1964 \\
\hline WELL & $327 \mathrm{LEE}$ & 46.00 & 1 & 1954 & 1954 \\
\hline WELL & $327 L E E$ & 92.00 & 1 & 1965 & 1965 \\
\hline WELL & $327 \mathrm{LEE}$ & - & 1 & 1960 & 1960 \\
\hline WELL & 327 LEE & - & 1 & 1960 & 1960 \\
\hline WELL & 327 LEE & - & 1 & 1960 & 1960 \\
\hline WELL & $111 \mathrm{AMOT}$ & 110.00 & 1 & 1958 & 1958 \\
\hline WELL & $324 B R T T$ & 204.00 & 1 & 1964 & 1964 \\
\hline WELL & $324 B R T T$ & 138.00 & $i$ & 1964 & 1964 \\
\hline WELL & $324 \mathrm{BRTT}$ & 36.00 & 1 & 1954 & 1954 \\
\hline WELL & & 240.00 & 1 & 1964 & 1964 \\
\hline WELL & $324 \mathrm{BRTT}$ & 125.00 & 1 & 1964 & 1964 \\
\hline WELL & 324 ERTT & 260.00 & 1 & 1953 & 1953 \\
\hline
\end{tabular}

SITE

GEOLOGIC
UNIT

WEL

ELACK STAR COAL CORP.

364419083254001 ELACK STAR

365047083083201 PEABOCY COAL CO

365100083173401 CLCVER FCRK COAL CO.

36510EC8 092201 FEABCOY COAL CC.

365147083191501 CHAPPELL DAIRY

365.2008J261201 JOROAN SAYLOR

365301083011301 O. SAYLOR

365733082564501

365738082565701

365740082565501

365742083034001

UNKNOWN

INTERNATIONAL HARVESTER

MAGGARD "E"

WISC "Q"

WELL
WELL
WE
WEL
WEL
WELL
WELL
WELL
WELL
WEL
WEL
WELL
WEL

324 BRTT 324 ERT

324 BRTT

320 PSLV

$327 \mathrm{LEE}$

324BRTT

$324 \mathrm{BRTT}$

320 PSLV

327 LEE $\begin{array}{cccr} & \\ \text { DEPTH } & \text { NUMBER } & \text { BEGINING } & \text { ENDI } \\ \text { OF } & \text { OF } & \text { YEAR } & \text { YEA }\end{array}$

250.00

200.00

520

500.00

43.0

40.0

.

56.00
1953

1958

1953

1953

1958

1954

1954

1953

1977

1976 


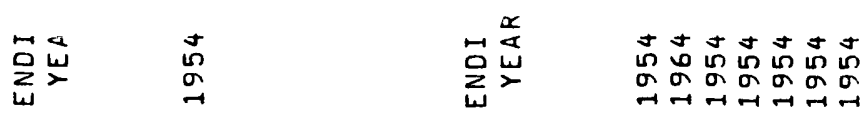

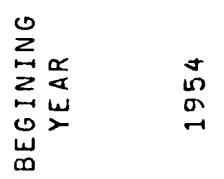

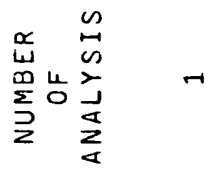

$\begin{array}{lll}I & a & 0 \\ 0 & 0 & 0 \\ 0 & 0\end{array}$

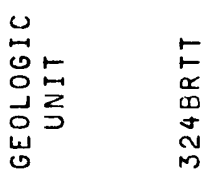

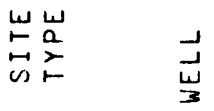

2
$x$
0
2
2
$w$
$x$
2
5
3
0
0
2
0
0
$y$
0
5
2

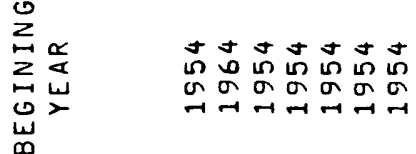

$\sum_{\sum}^{\infty} \sum_{\substack{\infty \\ 0}}^{\infty} \sum_{0}^{\infty}$

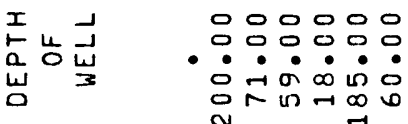

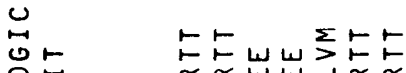

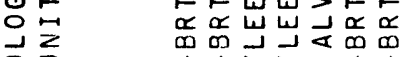

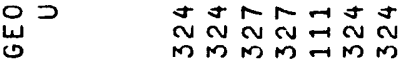

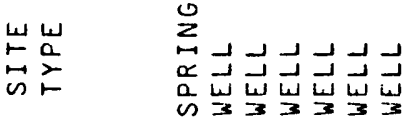

$\sum_{w}^{0} \frac{\alpha}{2}$

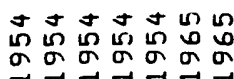

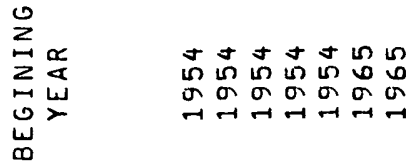

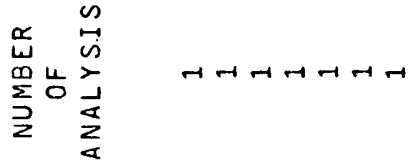

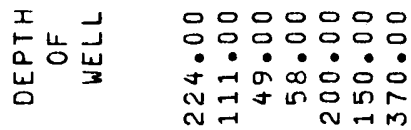

心ே

员

w $\quad N N N N N N$

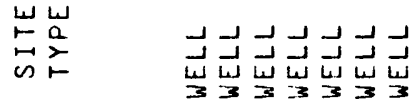

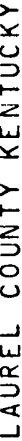

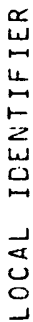

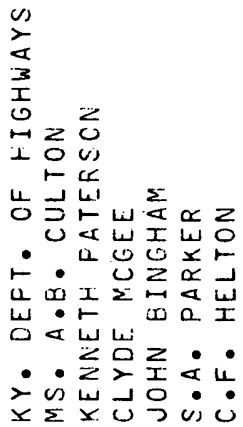

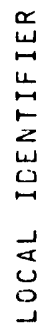

$\underset{\sim}{\sim}$

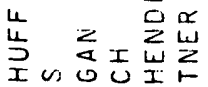

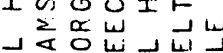

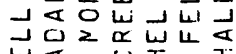
出的U现

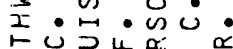

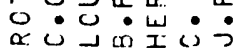

펌

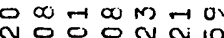

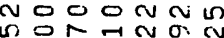

(i) in a 0 a

$m M m+M M M$

$\omega \infty \omega \infty \infty \infty$

0000000

A $\rightarrow$ N

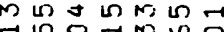

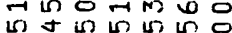

(N) $\begin{aligned} & 0 \\ & \text { M }\end{aligned}$

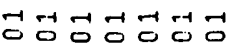
o. $\rightarrow 000$ a 0. $\infty$ d 0000000 - N

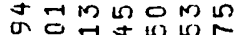

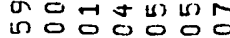
norón t $5 m m+t$ 
LETCHER COUNTY KENTUCKY

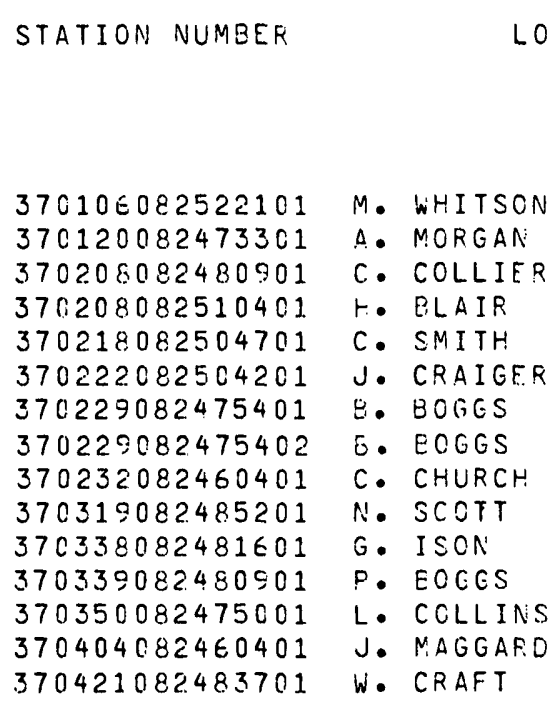

STATION NUMBER

$37010 E 082522101$ M. WHITSON

370120082473301 A. MORGAN

370208082480901 C. COLLIER

370208082510401 t. ELAIR

370218082504701 C. SMITH

370222082504201 J. CRAIGER

370229082475401 E. BOGES

370229082475402 E. EOGGS

370232082460401 C. CHURCH

$370319082485201 \quad$ N. SCOTT

370338082481601 G. ISON

370339082480901 P. EOCES

370350082475001 L. CCLLINS

370404082460401 J. MAGGAF.D

370421082483701 W. CRAFT

LOCAL IOENTIFIER

\begin{tabular}{|c|c|c|c|c|c|}
\hline $\begin{array}{l}\text { SITE } \\
\text { TYPE }\end{array}$ & $\begin{array}{l}\text { GEOLOGIC } \\
\text { UNIT }\end{array}$ & $\begin{array}{c}\text { DEPTH } \\
\text { OF } \\
\text { WELL }\end{array}$ & $\begin{array}{c}\text { NUMBER } \\
\text { OF } \\
\text { ANALYSIS }\end{array}$ & $\begin{array}{l}\text { BEGINING } \\
\text { YEAR }\end{array}$ & $\begin{array}{c}\text { ENDING } \\
\text { YEAR }\end{array}$ \\
\hline WELL & $324 B R T T$ & 93.00 & 1 & 1954 & 1954 \\
\hline WELL & 324 ERTT & 18.00 & 1 & 1960 & 1960 \\
\hline WELL & 111 AMOT & 12.00 & 1 & 1954 & 1954 \\
\hline WELL & $324 B R T T$ & 120.00 & 1 & 1960 & 1960 \\
\hline WELL & $324 B R T T$ & 48.10 & 1 & 1960 & 1960 \\
\hline$h^{\prime} E L L$ & $324 B R T T$ & 16.50 & 1 & 1960 & 1960 \\
\hline WELL & $324 B R T T$ & 51.00 & 2 & 1960 & 1962 \\
\hline WELL & $111 \mathrm{ALVM}$ & 12.00 & 1 & 1960 & 1960 \\
\hline WELL & 111 AMOT & 10.00 & 1 & 1960 & 1960 \\
\hline WELL & $324 \mathrm{BRTT}$ & 32.50 & 1 & 1960 & 1960 \\
\hline WELL & 327. LEE & 28.00 & 1 & 1960 & 1960 \\
\hline WELL & $324 B R T T$ & 6.00 & 1 & 1960 & 1960 \\
\hline WELL & 327 LEE & 96.00 & 1 & 1960 & 1960 \\
\hline WELL & $111 \mathrm{AMOT}$ & 9.50 & 1 & 1960 & 1960 \\
\hline WELL & 327 LEE & 50.40 & 1 & 1960 & 1960 \\
\hline
\end{tabular}

MCCREARY COUNTY KENTUCKY

STATION NUMBER LOCAL IDENTIFIER

265127084232401 J.E.PATRICK

FULASKI COUNTY KENTUCKY

STATION NUMPER

LOCAL J.DENTIFIER

370647084200801 W.H. WHITAKER

ROCKCASTLE COUNTY KENTUCKY

STATION NUMBER

LOCAL IDENTIFIER

371732084212001

372028084114101

372317084104601

372454084113101

372756084113501

J.e. CALHOUN

CALPOU

E. W. BAKER

GENFRO VALLEY ENT.

M.M. STEWARO

SITE

GEOLOGIC
UNIT

DEPTH
OF

WELL OF

BEGINING

YEAR

ENDING

YEAR

332 CSTR

121.0

1955

1955

$$
\begin{aligned}
& \text { SITE } \\
& \text { TYPE }
\end{aligned}
$$

GEOLOGI
UNIT

DEPTH
OF

NUMBER

BEGINING

YEAR

WELL ANALYSIS

WELL 333 SGVV

WELL 327 LEE

WELL 338WVR

WELL 338 WVRL

WELL $327 L E E$

46.00
71.00
48.00
85.00
50.0

1954

$1954 \quad 1954$

$\begin{array}{ll}1954 & 1954 \\ 1954 & 1954\end{array}$

$1954 \quad 1954$

WHITLEY COUNTY KENTUCKY

STATION NUMBEF

LOCAL IDENTIFIEF:

SITE
TYPE
WELL
WELL
WELL
WELL
WELL
WELL
WELL

GEOLOGIC

DEP

NUMBER

BEGINING

ENDING

WELL ANALYSIS

364202084120101 LAJOK CORF-HARVARE UNIVERSITY

364444084011501 G.C. LAH'SON

364617084104201 O. ROSS \#3, 0. WATSON

364727084005801 J.W. HILL

364902084115201 NOM. FUSON 36513084051901 CITIZEN ICE FUEL CO.

365525084132001

CITIZEN ICE

$327 L E E$

327 LEE

327 LEE

327 LEE

327 LEE

35.00

35.00

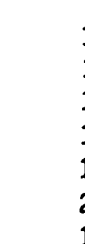

1
1
1
1
1
2
1

1967
1954
1967
1955
1955
1952
1954

1967

1954

1955

1958

1958
1954 


\subsection{LIST OF REFERENCES}

Bower, David E., and Jackson, William H.,1981, Drainage areas of streams at selected locations in Kentucky: U.S. Geological Survey Open-file report $81-51,118 \mathrm{p}$.

Carter, James P., and Jones, Albert R., 1969, Inventory and classification of streams in the upper Cumberland River drainage, Kentucky Fisheries Bulletin No. 52, 70 p.

Currens, J. C., and Smith, G. E., 1977, Coal production in Kentucky, 1790-1975: Kentucky Geological Survey Information Circular 23, 66 p.

Division of Water Resources, 1979, Rainfall frequency values for Kentucky: Commonwealth of Kentucky, Department of National Resources and Environmental Protection, Engineering Memorandum No. 2, 37 p.

Dyer, K. L., and Curtis, W.R., 1977. Effects of strip mining on water quality in small streams in eastern Kentucky, 1967-1975: U.S. Department of Agriculture, Forest Service research paper $\mathrm{NE}-372,13 \mathrm{p}$.

Englund, K.J., and Roen, J.B., 1962, Origin of the Middlesboro Basin, Kentucky: U.S. Geological Survey Professional Paper 450-E, p. E20-E22.

Faust, R. J., Banfield, G. R., and Willinger, G. A., 1980, A Compilation of ground water quality data for Kentucky: U.S. Geological Survey Open-File Report 80-685, 963 p.

Fenneman, N.M., 1938, Physiography of the Eastern United States, New York, New York, McgrawHill, $714 \mathrm{p}$.

----1946, Physical divisions of United States: U.S. Geological Survey (map), scale 1:7,000,000.

Hannum, C. H., 1976, Technique for estimation magnitude and frequency of floods in Kentucky: U.S. Geological Survey WRI 76-62, 70 p., + 1 plate.

Harvey, C. E., 1977, The economics of Kentucky coal: The University Press of Kentucky, Lexington, $173 \mathrm{p}$.

Hem, J. D., 1970, Study and interpretation of the chemical characteristics of natural water: U.S. Geological Survey Water-Supply Paper 1473. $363 \mathrm{p}$.

Hendrickson, G. E., 1958, Summary of occurrence of ground water in Kentucky: U.S. Geological Survey Hydrologic Investigations Atlas HA-10, 1 sheet.

Hopkins, Herbert T., 1966, Fresh-saline water interface map of Kentucky: Kentucky Geological Survey Series 10.

Huddle, J.W., Lyons, E.J., Smith, H.L., Ferm, J.C., and others, 1963, Coal reserves of eastern
Kentucky: U.S. Geological Survey Bulletin 1120, $247 p$.

Kentucky Department for Natural Resources and Environmental Protection, Division of Water (Quality), 1975, Kentucky water quality report to Congress: Frankfort, Ky., 225 p.

Kentucky Geological Survey, 1979, Generalized geologic map of Kentucky: University of Kentucky, Lexington, 1 plate, scale 1:1,000,000.

Kilburn, Chabot, Price, Jr., W.E., and Mull D.S., 1962, Availability of ground water in Bell, Clay, Jackson, Knox, Laurel, Leslie, McCreary, Owsley, Rockcastle, and Whitley Counties, Kentucky: U.S. Geological Survey Hydrologic Investigations, Atlas HA-38, 3 sheets.

Kirkpatrick, H. N., 1979, Annual Report Kentucky Department of Mines and Minerals, 1978: Commonwealth of Kentucky, Department of Mines and Minerals, $218 \mathrm{p}$.

Leamon, A.R., and Maher, S.W., 1974, Coal mining in Tennessee, State of Tennessee information circular $17,29 \mathrm{p}$.

May, V. J., and others, 1981, Hydrology of Area 18, Eastern Coal Province, Tennessee: U. S. Geological Survey Water Resources Investigations 81-492, $73 \mathrm{p}$.

McCabe, J. A., 1962, Floods in Kentucky-Magnitude and frequency: U.S. Geological Survey Information Circular 9, 196 p. + 1 plate.

McFarlan, A. C., 1943, Geology of Kentucky: Lexington, Ky., University of Kentucky, 531 p. (Reprinted 1961, Kentucky Department Economic Development).

Mull, D.S., and Pickering, R.J., 1968, Water resources of the Middlesboro area, Kentucky: Kentucky Geological Survey series 10, Report of Investigations 9, $51 \mathrm{p}$.

Murray, C. R., and Reeves, E. B., 1977, Estimated use of water in the United States in 1975: U.S. Geological Survey Circular 765, 39 p.

National Oceanic and Atmospheric Administration, 1973, Monthly normals of temperature, precipitation, and heating and cooling degree days 1941-70: U.S. Department of Commerce Pub. No. 81 (KY), 7 p.

Newcome, R., and Smith O., 1958, Ground-water resources of the Cumberland Plateau in Tennessee: Water Policy Commission, Tennessee Division of Water Resources, 64 p.

Price, Jr., W.E., Mull, D.S., and Kilburn, Chabot, 1962, Reconnaissance of ground-water resources in the Eastern Coal Field region, Kentucky: U.S. Geological Survey Water Supply Paper 1607, 56 p. 
Quinones, F., Kiesler, J., and Macy, J. A., 1980, Flow-duration at selected stream sites in Kentucky: U.S. Geological Survey Open-File Report 80-1221, $143 \mathrm{p}$.

Quinones, F., Mull, D.S., York, K.L., and Kendall, V., 1981, Hydrology of Area 14 Eastern Coal province, Kentucky, Water Resources Investigations 81-137, $145 \mathrm{p}$.

Randolph, W.J., and Gamble, C.R., 1976, Technique for estimating magnitude and frequency of floods in Tennessee: Tennessee Department of Transportation, $52 \mathrm{p}$.

Rice, Charles L., Sable, Edward G., Dever, Jr., Garland R., and Kehn, Thomas M., 1979, The Mississippian and Pennsylvanian

(Carboniferous) Systems in the United StatesKentucky: U.S. Geological Survey Professional Paper 1110-F, $32 \mathrm{p}$.

Rickert, D.A., Ulman, W.J., and Hampton, E.R., 1979, Synthetic fuels development, earth science considerations: U.S. Department of Interior / Geological Survey, $45 \mathrm{p}$.

Searcy, James K., 1959, Flow duration curves: U.S. Geological Survey Water supply Paper 1542-A, $33 \mathrm{p}$.

Soil Conservation Service, 1974, General soil map of Kentucky: Soil Conservation Service, 1 plate , scale 1:750,000.

-----,1978, General soil map Tennessee: Soil Conservation Service, 1 plate, scale 1:750,000.

State Conservation Needs Inventory Committee, 1970, Kentucky soil and water conservation needs inventory: Commonwealth of Kentucky, Division of Soil and Water Conservation Special Report, 256 p.

Sullavan, J. N., 1980, Low-flow characteristics of Kentucky streams: U.S. Geological Survey Open-File Report 80-1225, 1 plate.

Swisshelm, R. V., 1974, Low-flow characteristics of Kentucky streams: U.S. Geological Survey Open-File Report, 1 plate,

Tennessee Division of Geology, 1966, Geologic map of Tennessee, East-Central sheet, 1 plate.

U.S. Department of Commerce, 1961, Rainfall frequency atlas of the United States: Weather Bureau Technical Paper No. 40, $61 \mathrm{p}$.

U.S. Environmental Protection Agency, 1976, Quality criteria for water: Environmental Protection Agency Report, 256 p.

-----, 1977, National interim primary drinking water regulations: Environmental Protection Agency report 570/9-76-003, $159 \mathrm{p}$.

U.S. Geological Survey, 1980, Water resources data for Kentucky annual reports: U.S. Geological Survey, Louisville, Kentucky, 804 p.

Whitesides, D.V., Kernodle, J.M., and Leist, David W., 1978, Water levels in observation wells in Kentucky 1935 through 1976: U.S. Geological Survey Open-File Report 78-129, 156 p.

Zogorski, J. S., and Kiesler, J. L., 1976, Water temperatures of Kentucky: U.S. Geological Survey Water Resources Investigations 76-86, 1 plate. 